NBER WORKING PAPER SERIES

\title{
CHINA'S FINANCIAL SYSTEM: OPPORTUNITIES AND CHALLENGES
}

\author{
Franklin Allen \\ Jun "QJ" Qian \\ Chenying Zhang \\ Mengxin Zhao \\ Working Paper 17828 \\ http://www.nber.org/papers/w17828 \\ NATIONAL BUREAU OF ECONOMIC RESEARCH \\ 1050 Massachusetts Avenue \\ Cambridge, MA 02138 \\ February 2012
}

We wish to thank Joseph Fan, Randall Morck, our discussant Chenggang Xu and participants at the NBER's "Capitalizing China" Conference for helpful comments, Bibo Liu and Zhenrui Tang for excellent research assistance, Yingxue Cao and Lynn Yin for sharing data and information on China's real estate markets, and Boston College and the Wharton Financial Institutions Center for financial support. The authors are responsible for all the remaining errors. The views expressed herein are those of the authors and do not necessarily reflect the views of the National Bureau of Economic Research.

NBER working papers are circulated for discussion and comment purposes. They have not been peerreviewed or been subject to the review by the NBER Board of Directors that accompanies official NBER publications.

(C) 2012 by Franklin Allen, Jun "QJ" Qian, Chenying Zhang, and Mengxin Zhao. All rights reserved. Short sections of text, not to exceed two paragraphs, may be quoted without explicit permission provided that full credit, including $(\mathcal{C}$ notice, is given to the source. 
China's Financial System: Opportunities and Challenges

Franklin Allen, Jun "QJ" Qian, Chenying Zhang, and Mengxin Zhao

NBER Working Paper No. 17828

February 2012, Revised April 2012

JEL No. J2,K0,O5

\begin{abstract}
$\underline{\text { ABSTRACT }}$
We provide a comprehensive review of China's financial system, and explore directions of future development. First, the financial system has been dominated by a large banking sector. In recent years banks have made considerable progress in reducing the amount of non-performing loans and improving their efficiency. Second, the role of the stock market in allocating resources in the economy has been limited and ineffective. We discuss issues related to the further development of China's stock market and other financial markets. Third, the most successful part of the financial system, in terms of supporting the growth of the overall economy, is a non-standard sector that consists of alternative financing channels, governance mechanisms, and institutions. The co-existence of this sector with banks and markets can continue to support the growth of the Hybrid Sector (non-state, non-listed firms). Finally, among the policies that will help to sustain stable economic growth in China are those that reduce the likelihood of damaging financial crises, including a banking sector crisis, a real estate or stock market crash, and a "twin crisis" in the currency marketland banking sector.
\end{abstract}

\author{
Franklin Allen \\ Wharton School \\ University of Pennsylvania \\ 3620 Locust Walk \\ Philadelphia, PA 19104 \\ and NBER \\ allenf@wharton.upenn.edu \\ Jun "QJ" Qian \\ Boston College \\ 140 Commonwealth Ave \\ Chestnut Hill, MA 02467 \\ qianju@bc.edu
}

\author{
Chenying Zhang \\ University of Pennsylvania \\ chezhang@wharton.upenn.edu \\ Mengxin Zhao \\ University of Alberta \\ mengxin.zhao@ualberta.ca
}




\section{Introduction}

In this paper we provide a comprehensive review of China’s financial system and extensive comparisons with other countries. Almost every functioning financial system includes financial markets and intermediaries (e.g., a banking sector), but how these two standard financial sectors contribute to the entire financial system and economy differs significantly across different countries. In this regard, we discuss what has worked and what has not within the two sectors, and consider the effects of further development on the entire economy. We also examine a non-standard financial sector, which operates outside the markets and banking sectors and consists of alternative financing channels, governance mechanisms, and institutions. Finally, we provide guidelines for future research on several unresolved issues, including how China's financial system can integrate into the world's markets and economy without being interrupted by damaging financial crises. Although there is no consensus regarding the prospects for China's future economic growth, a prevailing view on China's financial system speculates that it is one of the weakest links in the economy and it will hamper future economic growth.

We draw four main conclusions about China's financial system and its future development. First, when we examine and compare China's banking system and financial markets with those of both developed and emerging countries, we find China's financial system has been dominated by a large banking system. Even with the entrance and growth of many domestic and foreign banks and financial institutions in recent years, China’s banking system is still mainly controlled by the four largest state-owned banks. All of these 'Big Four' banks have become publicly listed and traded companies in recent years, with the government being the largest shareholder and retaining control. This ownership structure has served these banks well in terms of avoiding major problems encountered by major financial institutions in developed countries that are at the center of the 20072009 global financial crisis. Moreover, the level of non-performing loans (NPLs) over GDP has been steadily decreasing after reaching its peak during 2000- 2001. Continuing improvement of the banking system, including further development of financial institutions outside the Big Four banks and extending more credit to productive firms and projects, can help stabilize China's financial system in the short run, given the uncertainties in the Chinese and global economies.

Our second conclusion concerns China’s financial markets. Two domestic stock exchanges, the Shanghai Stock Exchange (SHSE hereafter) and Shenzhen Stock Exchange (SZSE) were established in 1990. Their scale and importance are not comparable to the banking sector; and they have not been effective in allocating resources in the economy, in that they remain speculative and 
driven by insider trading. In recent years the stock market has witnessed significant development. Going forward, financial markets are likely to play an increasingly significant role in the economy. We discuss several issues and potential problems related to increasing the size and scope and improving the efficiency of the stock and other financial markets.

Third, in an earlier paper, Allen, Qian and Qian (2005, AQQ hereafter) find that the most successful part of the financial system, in terms of supporting the growth of the overall economy, is not the banking sector or financial markets, but rather a sector of alternative financing channels, such as informal financial intermediaries, internal financing and trade credits, and coalitions of various forms among firms, investors, and local governments. Many of these financing channels rely on alternative governance mechanisms, such as competition in product and input markets, and trust, reputation and relationships. Together this alternative financial sector has supported the growth of a "Hybrid Sector" with various types of ownership structures. Our definition of the Hybrid Sector includes all non-state, non-listed firms, including privately or individually owned firms, and firms that are partially owned by local governments (e.g., Township Village Enterprises or TVEs). ${ }^{1}$ The growth of the Hybrid Sector has been much higher than that of the State Sector (state-owned enterprises or SOEs, and all firms where the central government has ultimate control) and the Listed Sector (publicly listed and traded firms with most of them converted from the State Sector). The Hybrid Sector contributes most of China's economic growth, and employs the majority of the labor force. The co-existence of the alternative financial sector with banks and markets can continue to fuel the growth of the Hybrid Sector.

Finally, a significant challenge for China's financial system is to avoid damaging financial crises that can severely disrupt the economy and social stability. These crises include traditional financial crises: a banking sector crisis stemming from an accumulation of NPLs and a sudden drop in banks' profits; or a crisis/crash resulting from speculative asset bubbles in the real estate market or stock market. There are also other types of financial crises, such as a "twin crisis" (simultaneous foreign exchange and banking/stock market crises) that struck many Asian economies in the late 1990s. Since its entrance to the World Trade Organization (WTO) in 2001, the integration of China's financial system and overall economy with the rest of the world has significantly sped up. This process introduces cheap foreign capital and technology, but large scale and sudden capital flows and

\footnotetext{
${ }^{1}$ We include firms partially owned by local governments in the Hybrid Sector for two reasons. First, despite the ownership stake of local governments and the sometimes ambiguous ownership structure and property rights, the operation of these firms resembles more closely that of a for-profit, privately-owned firm than that of a state-owned firm. Second, the ownership stake of local governments in many of these firms has been privatized.
} 
foreign speculation increase the likelihood of a twin crisis. At the end of 2007, China's foreign currency reserves surpassed US $\$ 1.5$ trillion, overtaking Japan to become the largest in the world; they increased to about US\$3.2 trillion as of June 2011 with a large fraction invested in U.S. dollar denominated assets such as T-bills and notes. ${ }^{2}$ The rapid increase in China's foreign exchange reserves suggests that there is a large amount of speculative, "hot" money in China in anticipation of a continuing appreciation of the RMB, China's currency, relative to all other major currencies, especially the US dollar. Depending on how the government and the central bank handle the process of revaluation, especially when there is a large amount of capital outflow, there could be a classic currency crisis as the government and central bank try to defend the partial currency peg, which in turn may trigger a banking crisis if there are large withdrawals from banks.

The remaining sections are organized as follows. In Section II, we briefly review the history of China's financial system development, present aggregate evidence on China's financial system, and compare them to those of developed and other developing countries. In Section III, we examine China's banking system and changes over time. In Section IV, we briefly examine the growth and irregularities of financial markets, including the stock market, real estate market, and listed firms, and consider the effects of several initiatives to develop new markets and further develop existing markets, as well as changes in corporate governance among listed firms. In Section V, we examine the non-standard financial sector, including alternative financial channels and governance mechanisms. Motivated by the success of this financial sector and firms in the Hybrid Sector, we also compare the advantages and disadvantages of using the law as the basis of finance and commerce. We then examine different types of financial crises and their potential effects on China's financial system in Section VI. Finally, Section VII concludes the paper. In terms of converting RMB into US dollar, we use the exchange rate of US $\$ 1=$ RMB 8.28 (yuan) for transactions and events occurring before 2005, and the spot rate at the end of each year for those activities during and after 2005 (Figure 8-B provides a graph of the exchange rates between the US dollar and the RMB).

\section{Overview of China's Financial System}

\section{II.1 A Brief Review of the History of China's Financial System}

China's financial system was well developed before $1949 .^{3}$ One key finding in reviewing the

\footnotetext{
${ }^{2}$ According to the U.S. Treasury Department, China's holding of U.S. treasury securities reached \$ 1.17 trillion in July 2011. Morrison and Labonte (2008) estimate that around 70\% of China's foreign reserves are invested in dollar denominated assets.

${ }^{3}$ For more descriptions of the pre-1949 history of China's financial system, see AQQ (2008); for more anecdotal evidence on China's financial system in the same period, see, for example, Kirby (1995) and Lee (1993).
} 
history of this period, including the rise of Shanghai as one of the financial centers of Asia during the first half of the $20^{\text {th }}$ Century, is that the development of China's commerce and financial system as a whole was by and large outside the formal legal system. For example, despite the entrance of Western-style courts in Shanghai and other major coastal cities in the early 1900s, most businessrelated disputes were resolved through mechanisms outside courts, including guilds (merchant coalitions), families and local notables. ${ }^{4}$ In Section V.3 below, we argue that modern equivalents of these nonlegal dispute-resolution and corporate governance mechanisms are behind the success of Hybrid Sector firms in the same areas in the 1980s and 1990s, and that these alternative mechanisms may be more responsive in adapting to changes in a fast-growing economy like China than the law and legal institutions.

After the foundation of the People's Republic of China in 1949, all of the pre-1949 capitalist companies and institutions were nationalized by 1950. Between 1950 and 1978, China’s financial system consisted of a single bank - the People's Bank of China (PBOC), a central government owned and controlled bank under the Ministry of Finance, which served as both the central bank and a commercial bank, controlling about 93\% of the total financial assets of the country and handling almost all financial transactions. With its main role to finance the physical production plans, the PBOC used both a “cash-plan” and a "credit-plan” to control the cash flows in consumer markets and transfer flows between branches.

The first main structural change began in 1978 and ended in 1984. By the end of 1979, the PBOC departed the Ministry and became a separate entity, while three state-owned banks took over some of its commercial banking businesses: The Bank of China ${ }^{5}$ (BOC) was given the mandate to specialize in transactions related to foreign trade and investment; the People's Construction Bank of China (PCBC), originally formed in 1954, was set up to handle transactions related to fixed investment (especially in manufacturing); the Agriculture Bank of China (ABC) was set up (in 1979) to deal with all banking business in rural areas; and, the PBOC was formally established as China's central bank and a two-tier banking system was formed. Finally, the fourth state-owned commercial bank, the Industrial and Commercial Bank of China (ICBC) was formed in 1984, and took over the rest of the commercial transactions of the PBOC.

\footnotetext{
${ }^{4}$ See, e.g., Chung (2005), for descriptions on family- and community-based mechanisms for contract enforcement. Looking at how disputes were resolved in and outside courts, Goetzmann and Köll (2005) conclude that the passing of China’s first Company law in 1904, which was intended to provide a better legal environment for business and commerce, did not lead to actual changes in corporate governance and better protection of (minority) shareholder rights.

${ }^{5}$ BOC, among the oldest banks currently in operation, was originally established in 1912 as a private bank, and specialized in foreign currency related transactions.
} 
For most of the 1980s, the development of the financial system can be characterized by the fast growth of financial intermediaries outside of the "Big Four” banks. Regional banks (partially owned by local governments) were formed in the Special Economic Zones in the coastal areas; in rural areas, a network of Rural Credit Cooperatives (RCCs; similar to credit unions in the U.S.) was set up under the supervision of the ABC, while Urban Credit Cooperatives (UCCs), counterparts of the RCCs in the urban areas, were also founded. Non-bank financial intermediaries, such as the Trust and Investment Corporations (TICs; operating in selected banking and non-banking services with restrictions on both deposits and loans), emerged and proliferated in this period.

The most significant event for China's financial system in the 1990s was the inception and growth of China’s stock market. Two domestic stock exchanges (SHSE and SZSE) were established in 1990 and grew very fast during most of the 1990s and in recent years in terms of the total market capitalization and trading volume. In parallel with the development of the stock market, the real estate market also went from nonexistent in the early 1990s to one that is currently comparable in size with the stock market. ${ }^{6}$ Both the stock and real estate markets have experienced major corrections during the past decade, and are characterized by high volatilities and speculative short-term behaviors by many investors.

These patterns are in part due to the fact that the development of a supportive legal framework and institutions has been lagging behind that of the markets. For example, China's first bankruptcy law (governing SOEs) was passed in 1986 on a trial basis, but the formal Company Law did not become effective until the end of 1999. This version of the Company Law governs all corporations with limited liability, publicly listed and traded companies, and branches or divisions of foreign companies, as well as their organization structure, securities issuance and trading, accounting, bankruptcy, mergers and acquisitions (for details see the website of China Securities Regulatory Commission (CSRC), http://www.csrc.gov.cn/). In August 2006, a new bankruptcy law was enacted, and it became effective June 1, 2007. We provide a brief analysis of the status and problems of the stock market and real estate market in Section IV below.

Following the Asian Financial Crisis in 1997, financial sector reform has focused on stateowned banks and especially the problem of NPLs (the China Banking Regulation Committee (CBRC) was also established to oversee the banking industry). We will further discuss this issue in Section III. China's entry into the WTO in December 2001 marked the beginning of a new era, as we continue to observe increasing competition from foreign financial institutions and more frequent and larger scale

\footnotetext{
${ }^{6}$ At the end of 2007, the total market capitalization of the two domestic exchanges (SHSE and SZSE) was around \$1.8 trillion, whereas total investment in the real estate market was around \$3.12 trillion.
} 
capital flows. While increasingly larger inflows of foreign capital and the presence of foreign institutions may continue to drive further growth of the financial system and economy, larger scale capital flows can also increase the likelihood of damaging financial crises. We will discuss these issues in Sections IV and VI.

A developed financial system is characterized by, among other factors, the substantial role played by institutional investors. In China, institutional investors began to emerge in the late 1990s: the first closed-end fund, in which investors cannot withdraw capital after initial investment, was set up in 1997, and the first open-end fund, in which investors can freely withdraw capital (subject to share redemption restrictions), was established in 2001. By November 2009, there were 65 fund companies managing 551 funds with 520 open-ended funds and the rest close-ended. The total net assets value (NAV) increased from RMB11 billion (or US\$ 1.3 Billion) in 1998 to RMB 2.26 trillion (or $\$ 328$ billion) in November 2009, which is still small compared to the assets within the banking sector. In 2003, a few Qualified Foreign Institutional Investors (QFII) entered China’s asset management industry, and they have been operating through forming joint ventures with Chinese companies. On the other hand, China allowed Qualified Domestic Institutional Investors (QDII) to invest in overseas markets beginning in July 2006. At the end of 2008, the ten QDII funds had a total of $\$ 109.4$ billion assets under management.

At the national level, the China Investment Corporation (CIC) was established in September 2007 with the intent of utilizing the accumulated foreign reserves for the benefit of the state and \$207.91 billion foreign reserves were placed under management at the establishment. CIC makes occasional announcements about its investment, but the overall transparency of its investment strategy is low. Since inception, CIC has made some aggressive investment decisions, including the well publicized \$3 billion (pre-IPO) investment in private equity group Blackstone, and the \$5 billion investment in Morgan Stanley (this took the form of mandatory convertible bonds that can be converted into almost $10 \%$ of the firm's equity).

Endowed with limited capital and given problems with the administration of the pension system, pension funds have not played a significant role in the stock or bond market. ${ }^{7}$ With a fast aging population and the growth of households' disposable income, further development of a multipillar pension system, including individual accounts with employees’ self-contributed (tax exempt)

\footnotetext{
${ }^{7}$ While there is a nationwide, government run pension system (financed mainly through taxes on employers and employees), the coverage ratio of the pension system varies significantly across regions and is particularly low in rural areas. Moreover, there is a very limited amount of capital in individual accounts and most of the capital has been invested in banks and government projects with low returns. See, for example, Feldstein $(1999,2003)$ and Feldstein and Liebman (2006), for more details on China's pension system.
} 
funds that can be directly invested in the financial markets, can lead to the development of both the financial system and the fiscal system as well as social stability. At the top of the pension fund system, China’s National Social Security Fund (NSSF) was established in August 2002 and is administered by the National Council for Social Security Fund. This (sovereign) fund is mainly financed by capital and equity assets derived from the listing of state-owned companies, fiscal allocations from the central government, and other investment proceeds. It has recently shifted its core investment strategy of focusing on the domestic A-share and bond markets to a more diversified basket of assets, including investments in emerging markets and Europe. At the end of 2008, the fund had a total of $\$ 89.2$ billion in assets; it grew to RMB856.7 billion ( $\$ 142.8$ billion) at the end of 2010 according to the annual report of NSSF. Finally, there are very few hedge funds that implement “long-short” strategies, as short selling has been prohibited until recently. ${ }^{8}$

\section{Insert Figure 1 here.}

Figure 1 depicts the current structure of the entire financial system. In what follows we will describe and examine each of the major sectors of the financial system. In addition to the standard sectors of banking and intermediation and financial markets, we will document the importance of the non-standard financial sector. Due to space limitation, we do not cover China’s “foreign sectors” in this chapter; for discussions on the history and the role of these sectors in supporting the growth of the economy, see, for example, Prasad and Wei (2007) for a review.

\section{II.2 Size and Efficiency of the Financial System: Banks, Markets, and Alternative Finance}

In Table 1, we compare China's financial system to those of other major emerging economies, with measures for the size and efficiency of banks and markets taken from Levine (2002) and Demirgüç-Kunt and Levine (2001) and data from the World Bank Financial Database. We present average figures over the period 2001-2007 for each country as well as the average of all the other emerging economies (excluding China). We first compare the size of a country's banks and equity markets relative to that country’s gross domestic product (GDP). In terms of total market capitalization, China's stock market, at 64\% of its GDP over the period 2001-2007, is slightly larger than the 58\% of GDP average of the other major emerging economies. "Value Traded" is perhaps a better measure of the actual size of the market than "market capitalization," because the latter includes non-tradable shares or tradable shares that are rarely traded. In this regard, the size of

\footnotetext{
${ }^{8}$ Along with the introduction of an index future (for A shares) in April 2010, a trial program on short selling began for selected institutional investors (security companies; see, e.g., www.wsj.com, 3/31/2010). The impact of introducing these new programs and products on the financial market is yet to be seen.
} 
China's stock market (62\% of GDP) is significantly larger than the average of other emerging economies (with an average of 37\% of GDP). Similarly, the size of China's banking system, in terms of total bank credit to non-state sectors, is $116 \%$ of its GDP over 2001-2007, and considerably larger than the average of other major emerging economies (with an average of 65\% of GDP). However, the majority of the bank credit goes to state-owned firms in China and only a small fraction goes to firms in the Hybrid Sector (more evidence of this is given below). In addition, NPLs account for a larger fraction of all the loans in China than the average of other emerging economies (16\% vs. 10\%), indicating that its banking sector still has scope to improve its efficiency. ${ }^{9}$

\section{Insert Table 1 here.}

The next two columns of Table 1 ("Structure indices”) compare the relative importance of financial markets vs. banks, with a lower score indicating that banks are more important relative to markets. China’s score for “Structure size” (Log of the ratio of Market Capitalization/Total Bank Credit) is positive, suggesting that the size of total market capitalization is actually larger than that of bank credit, and the score is greater than the average of other emerging economies; its score for “Structure Activity” (Log of the ratio of Float supply of market cap/Total Bank Credit) is negative, indicating that float supply fraction of the market cap is still smaller than bank credit, and it is similar to the average of other emerging economies. Taken together these numbers suggest that the financial system of most emerging economies, including that of China, remains bank-dominated. In terms of “Structure efficiency” (Log of product (Market capitalization/GDP) × (bank NPLs/bank total loans)), which denotes the relative efficiency of markets vs. banks, China has a higher score than most other developing countries, suggesting that its banks are relatively less efficient than markets compared to other countries. "Structure regulatory” measures (based on 2005 data) the extent to which commercial banks are restricted to participate in activities outside commercial lending, and China's score of 16 is higher than most other countries, suggesting that by law commercial banks in China face tight restrictions in operating in other areas.

We also compare the development of the financial system ("Financial Development”), including both banks and markets (the last three columns of Table 1). China's overall financial market size, in terms of both "Finance Activity” (Log of product of (Float supply of market/GDP) $\times$ (Bank credit/GDP)) and “Finance Size” (Log of product of (Market capitalization/GDP) + (Bank

\footnotetext{
${ }^{9}$ Levine (2002) uses bank overhead cost/total assets to measure banking sector efficiency, and used this measure to construct the "Structure Efficiency" and "Finance Efficiency" measures. However, the World Bank Financial Database no longer reports the overhead cost/assets ratio; we replace this with NPLs/loans ratio as an alternative measure of efficiency and use this variable to define other efficiency measures in Table 1.
} 
credit/GDP)), are larger than the averages of other emerging countries. In terms of "Finance Efficiency” (Log of (Total floating supply/GDP)/Bank NPLs Ratio), China’s measure is slightly higher than the average of other emerging countries. Based on the evidence from the past decade, we can conclude that China's banks and markets, or the formal sectors of the financial system, are as large as or larger than other major emerging economies (relative to its size of the economy). However, the banking sector does not lend much to the Hybrid Sector, which as we will see in Section $\mathrm{V}$, is the dynamic part of the economy.

A related question to the size of banks and markets is where do most firms get the capital and funds? As shown in AQQ (2005, 2008), the four most important financing sources for all firms in China, in terms of firms' fixed asset investments, are, (domestic) bank loans, firms' self-fundraising, the state budget and FDI, with self-fundraising and bank loans carrying most of the weight. Selffundraising, falling into the category of alternative finance (non-bank, non-market finance), includes proceeds from capital raised from local governments (beyond the state budget), communities and other investors, internal financing channels such as retained earnings and all other funds raised domestically by the firms. The size of total self-fundraising of all firms has been growing at an average annual rate of $23.6 \%$ over the period of 1994-2009, and reached \$2,213.2 billion at the end of 2009, compared to a total of $\$ 565.7$ billion for domestic bank loans for the same year. It is important to point out that equity and bond issuance, which are included in self-fundraising (but fall into the category of formal external finance), apply only to the Listed Sector, and account for a small fraction of this category.

While the Listed Sector has been growing fast, SOEs are on a downward trend, as privatization of these firms is still in progress. Around 30\% of publicly traded companies’ funding comes from bank loans, and this ratio has been very stable. Around $45 \%$ of the Listed Sector's total funding comes from self-fundraising, including internal financing and proceeds from equity and bond issuance. Moreover, equity and bond sales, which rely on the use of external markets, only constitute a small fraction of total funds raised in comparison to internal financing and other forms of fundraising. Combined with the fact that self-fundraising is also the most important source of financing for the State Sector (45\% to 65\%), we can conclude that alternative channels of financing are important even for the State and Listed Sectors.

Not surprisingly, self-fundraising plays an even more important role for firms in the Hybrid Sector, accounting for close to $60 \%$ of total funds raised, while individually owned companies, a subset of the Hybrid Sector, rely on self-fundraising for $90 \%$ of total financing. Self-fundraising here 
includes all forms of internal finance, capital raised from family and friends of the founders and managers, and funds raised in the form of private equity and loans. Since firms in this sector operate in an environment with legal and financial mechanisms and regulations that are probably poorer than those available for firms in the State and Listed Sectors, financing sources may work differently from how they work in the State and Listed Sectors, and those in developed countries. In Allen, Chakrabarti, De, Qian, and Qian (ACDQQ, 2008), the authors argue that alternative finance channels, substitute for formal financing channels through banks and markets, and expand the capacity of financial systems in emerging countries such as China and India.

\section{The Banking and Intermediation Sector}

In this section, we examine the status of China's banking and intermediation sector. After reviewing aggregate evidence on bank deposits and loans, we analyze the size and time trend of NPLs. Finally, we review evidence on the growth of non-state banks and financial intermediaries.

\section{III.1 Aggregate Evidence on Bank Deposits and Loans}

As in other Asian countries, China's household savings rates have been high throughout the reform era. Given the growth of the economy, the sharp increase in personal income, and limited investment opportunities, it is not surprising that total bank deposits from individuals have been growing fast since the mid-1980s. From Figure 2-A, residents in metropolitan areas contribute the most to total deposits beginning in the late 1980s (roughly 50\%), while deposits from enterprises (including firms from all three sectors) provide the second most important source. The role of deposits from government agencies and organizations (including non-profit and for-profit organizations, not shown in the figure) has steadily decreased over time.

\section{Insert Tables 2-A, 2-B, and Figures 2-A and 2-B here.}

Table 2-A compares total savings and bank deposits in China, Japan, South Korea, and India during the period 1997-2009. In terms of the ratio of Time and Savings Deposits/GDP, China maintains the highest or second highest level (an average of over 90\% in recent years), while Japan leads the group in terms of total amount. Looking at the breakdown of bank deposits, interestbearing “savings deposits” are by far the most important form of deposits in China, providing a good source for bank loans and other forms of investment. Figure 2-B compares total (nonstate) bank credit (over GDP) extended to Hybrid Sector firms in China, and privately owned firms (including those publicly listed and traded) in Taiwan and South Korea. For South Korea, we also plot the bank credit ratios during its high economic growth period of the 1970s and 1980s (each year appearing on 
the horizontal axis indicates the time period for China, while a particular year minus 20 indicates the time period for South Korea). We can see that the scale and growth of China's 'hybrid' bank credit during 1991-2009 are far below those (of private bank credit) of Taiwan and South Korea in the same period, but are similar to those of South Korea twenty years ago.

Table 2-B breaks down China’s bank loans by maturities, loan purposes, and borrower types during the period 1994-2009. While there has been a shift from short-term to long-term loans (first two columns), the majority of loans goes to SOEs in manufacturing industries ("Industrial Loans” and "Commercial Loans”). Most of the "Infrastructure/Construction Loans” (a small component of total loans) fund government sponsored projects, while the size of “Agricultural Loans” is much smaller. More importantly, the size of loans made to TVEs, privately- and collectively-owned firms, and joint ventures (last 3 columns), which all belong to the Hybrid Sector, is also much smaller. Consistent with the aggregate evidence from Section II above and our firm-level evidence below, we

find that bank loans have been one of the important financing sources for Hybrid Sector firms, but the majority of the bank loans goes to the State and Listed Sectors. Researchers have argued that the imbalance between loans made to the State Sector and the Hybrid Sector reflects the government's policies of wealth transfer from the Hybrid Sector to the State Sector via state-owned banks (e.g., Brandt and Zhu, 2000).

\section{III.2 An Analysis of NPLs and Further Reform of the Banking Sector}

China's banking sector is dominated by large state-owned banks, namely, the "Big Four" banks of ICBC, BOC, PCBC, and ABC. The dominance of the Big Four banks also implies that the degree of competition within the banking sector has been low. For example, Demirgüç-Kunt and Levine (2001) compare the five-bank concentration (share of the assets of the five largest banks in total banking assets), and find that China's concentration ratio of 91\% at the end of 1997 (and for much of 1990s) is one of the highest in the world. However, China's concentration ratio has been falling sharply since 1997 with the entrance of many non-state banks and intermediaries.

The most significant problem for China’s banking sector, and for the entire financial system during the last decade, was the amount of NPLs within state-owned banks, and in particular, among the Big Four banks. Reducing the amount of NPLs to normal levels was a high priority for China’s financial system. We mainly rely on official sources for our analysis on NPLs, but we also speculate based on data from non-government sources, including case studies from particular regions or banks. 
Some of this data and speculations paint a much gloomier picture of the NPLs and China's stateowned banks than the official data suggests.

\section{Comparing NPLs and Reducing NPLs in China}

In Panel A of Table 3-A, we compare NPLs in China, the U.S., and other major Asian economies during 1998-2010 based on official figures. NPLs are measured by their size (in US\$ billion) and as a percentage of GDP in the same year (shown in brackets). Notice that the official information on China's NPLs first became available in 1998, but the figures in 1998 and 1999 in Table 3-A probably significantly under-estimate the actual size of NPLs; this also explains the jump in the size of China's NPLs from 1999 to 2000. China’s NPLs are the highest in the group from 2000 to 2007, and as high as 20\% to 22.5\% of GDP (in 2000 and 2001). The cross-country comparison includes the period during which Asian countries recovered from the 1997 financial crisis (e.g., the size of NPLs in South Korea exceeded 12\% of GDP in 1999 but it was reduced to below 3\% two years later), and the period during which the Japanese banking system was disturbed by the prolonged NPL problem (the size of Japan's NPLs is the second largest of the group throughout the period). However, the level of NPLs (over GDP) in China has shown a clear downward trend since the peak in 2000-2001, with the total amount of NPLs also falling during 2004-2010. In fact, with the banking sector in most developed countries struggling with the ongoing global financial crisis, China’s banking sector has done quite well, with its total NPLs in 2010 (\$68.1 billion) only one seventh of that of the U.S. and the ratio of NPLs over GDP falling below that of the U.S. as well.

\section{Insert Table 3-A here.}

As bad as some of the NPL numbers in early years in Panel A of Table 3-A appear, they may still significantly underestimate the amount of NPLs within China's banking system according to some critics. First, the official figures on outstanding NPLs (cumulated across all commercial banks in China) do not include the bad loans that have been transferred from banks to four state-owned asset management companies (AMCs) — with the purpose of liquidating these bad loans. For example, if we add the NPLs held by the four AMCs (book value of RMB 866 billion, or \$125.5 billion, shown in the last row of Table 3-B) in the first quarter of 2006 to the mix of NPLs shown in Panel A of Table 3-A, the total amount of China's NPLs would increase by two-thirds. Second, the classification of NPLs has been problematic in China. The Basle Committee for Bank Supervision classifies a loan as “doubtful” or bad when any interest payment is overdue by 180 days or more (in the U.S. it is 90 days); whereas in China, this step has not typically been taken until the principal payment is delayed beyond the loan maturity date or an extended due date, and in many cases, until 
the borrower has declared bankruptcy and/or has gone through liquidation. Qiu et al. (2000) estimate that the ratio of loan interest paid to state-owned banks over loan interest owed is on average less than 50\% in 1999, suggesting that the actual ratio of NPLs over total loans made can be higher than $50 \%$ in 1999. This piece of evidence, along with others, suggests that the amount of NPLs (and as a percentage of GDP) could be twice as large as the official figures reported in Panel A of Table 3-A. ${ }^{10}$ Since a large fraction of the NPLs among state-owned banks, and in particular, the Big Four banks, resulted from poor lending decisions made for SOEs, some of which were due to political or other non-economic reasons, it can be argued that the natural party to bear the burden of reducing the NPLs is the government. This view of essentially treating NPLs as a fiscal problem implies that the ultimate source of eliminating NPLs lies in China's overall economic growth. ${ }^{11}$ As long as the economy maintains its strong growth momentum so that tax receipts also increase, the government can always assume the remaining (and new) NPLs without significantly affecting the economy. In this regard, Panel B of Table 3-A compares total outstanding government debt, and Panel C presents a comparison of the ratio of (NPLs + Government Debt)/GDP across countries, with the sum of NPLs and government debt indicating the total burden of the government. Depending on data availability, total government debt is either measured by the sum of all types of domestic and foreign debt (the U.S., Japan, and India), or by the level of outstanding government bonds (all other countries) in a given year.

Unlike the severity of its NPL problem in the early 2000s, the Chinese government has not issued a large amount of debt, with total outstanding government bonds growing from only 9\% of GDP in 1998 to around 20\% of GDP in 2010. By contrast, countries such as the U.S. and India have a large amount of government debt. Japan is the only country in the group that has a large amount of NPLs and government debt for most of the period. When we combine the results from Panels A and B and compare the total government burden in Panel C, we use two sets of ratios for U.S. and Japan. In addition to using total outstanding government debt, we use ratios (in the brackets) based on the sum of net government debt and NPLs, where net government debt is the difference between government borrowing (a 'stock’ measure) and government lending (also a stock measure); not surprisingly, these ratios are much lower than using the gross figures.

From Panel C, China's total government burden is in the middle of the pack: the ratios of total

\footnotetext{
${ }^{10}$ Consistent with this view, Lardy (1998) argues that, if using international standards on bad loans, the existing NPLs within China's state-owned banks as of the mid-1990s would make these banks' total net worth negative, so that the entire network of state banks would have been insolvent.

${ }^{11}$ See, for example, Perkins and Rawski (2008) for a review and projections on the prospects of long-run economic growth and statistics in China.
} 
government burden over GDP (using the official NPL figures) are significantly lower than those in Japan, the U.S., and India, are comparable with those of Taiwan and Korea, and are higher than Indonesia only. In recent years, even if we double the size of the official NPL figures, China's total government burden would not increase much as the total amount of NPLs is small relative to the size of GDPs. Based on these crude comparisons, going forward it seems that the NPLs should not be an arduous burden for the Chinese government (or the banking sector), while the same cannot be said for Japan and the U.S. Caution is needed for this conclusion: first, new NPLs in China may grow much faster than other countries as the government's recent massive economic stimulus plan led to a significant increase in new loans made during 2008-2009, including many questionable loans to local governments ${ }^{12}$; and second, China's currently small government debt may experience a sharp increase in the near future given the need for higher fiscal spending in areas such as pension plans and other social welfare programs.

Recognizing the importance of and its responsibility in reducing NPLs in the Big Four banks, the Chinese government injected large amounts of foreign currency reserves (mostly in the form of US dollars, T-bills, Euros and Yen) into these banks to improve their balance sheets in preparation for going public. This process began at the end of 2003, with the establishment of the Central Huijin Investment Company, through which the PBOC injected US\$45 billion of reserves into the BOC and PCBC, while ICBC (the largest commercial bank in China and one of the largest in the world in terms of assets) received US\$15 billion during the first half of 2005. In 2008, ABC received US\$19 billion from Huijin in spite of the global financial crisis. All Big Four banks have since become publicly listed and traded on either the HKSE and/or the SHSE, including ABC (the last of the Big Four), which completed its IPO on July 15, 2010 (SHSE) and July 16 (HKSE).

However, the injection plan will not prevent new NPLs from originating in the banking system. In fact, it may create perverse "too big to fail” incentives for state-owned banks, in that if these banks believe that there will be a 'bailout' whenever they run into future financial distress, they have an incentive to take on risky, negative-NPV projects. This moral hazard problem can thwart the government's efforts in keeping the NPLs in check, while similar problems occurred during and after the government bailouts in the S\&L crisis in the U.S. in the 1980s (e.g., Kane 1989, 2003) and are among the most significant factors that caused the ongoing financial crisis. In this regard, a credible

\footnotetext{
${ }^{12}$ According to senior officials from the CBRC, Chinese banks are facing default risks on more than one-fifth of the RMB7,700bn (\$1,135bn) loans they have made to local governments across the country; most of these loans were used to fund regional infrastructure projects (Financial Times, 08/01/2010). In July 2011, Moody estimated that local government loans can be as high as RMB14.2 trillion, and the NPL ratio for Chinese banks could be 8-12\% (Reuters, 07/05/2011).
} 
commitment from the government that the capital injection plan is a one-time measure to boost the capital adequacy of these banks, and that there will be no (similar) injection plans in the future can help alleviate the moral hazard problem.

Another measure taken by the Chinese government to reduce the NPLs is the establishment of four state-owned AMCs. As discussed earlier, the goal of the AMCs is to assume the NPLs (and offering debt-for-equity swaps to the banks ${ }^{13}$ ) accumulated in each of the Big Four banks and liquidate them. The liquidation process includes asset sales, tranching, securitization, and resale of loans to investors. ${ }^{14}$ Table 3-B shows that cash recovery on the bad loans processed by the AMCs ranges from $6.9 \%$ to 35\% between 2001 and 2006 (first quarter) ${ }^{15}$, while the asset recovery rates are slightly higher. A critical issue that affects the effectiveness of the liquidation process is the relationship among AMCs, banks, and distressed or bankrupt firms. Since both the AMCs and the banks are state-owned, it is not likely that the AMCs would force the banks to cut off (credit) ties with defaulted borrowers (SOEs or former SOEs) as a privately owned bank would do. Thus, as the old NPLs are liquidated, new NPLs from the same borrowers continue to surface.

To summarize, NPLs have been considerably reduced in recent years. If the economy can maintain its current pace of growth, the government can always write off a large fraction of the rest (and newly accumulated) of the NPLs to avert any serious problems for China. Again, caution is in place for this optimistic outlook. One can argue that NPLs are bigger than the official statistics suggest to begin with, and that a substantial amount of new NPLs will continue to arise within stateowned banks. If the growth of the economy significantly slows down, while the accumulation of NPLs continues, the banking sector problems could lead to a financial crisis. This could spill over into other sectors of the economy and cause a slowdown in growth or a recession.

\section{Insert Tables 3-B and 4-A here.}

\section{The Efficiency of State-owned Banks}

As discussed above, the size of NPLs in the banking sector critically depends on the efficiency of banks. We briefly discuss measures that have been taken to improve the efficiency of state-owned banks. First, state-owned banks have diversified and improved their loan structure by

\footnotetext{
${ }^{13}$ One example is Cinda Asset Management Corporation, which was set up in April, 1999, with a registered capital of RMB 10 billion provided by the Ministry of Finance. It took over RMB 220 billion NPLs from the China Construction Bank and funded its purchase via bond issues.

${ }^{14}$ The sale of tranches of securitized NPLs to foreign investors began in 2002. The deal was struck between Huarong , one of the four AMCs, and a consortium of U.S. investment banks led by Morgan Stanley (and including Lehman Brothers and Salomon Smith Barney) and was approved by the government in early 2003 (Financial Times, 05/2003).

${ }^{15}$ The China Banking Regulatory Commission (CBRC), from which we obtained data (for 2004-2009), stopped reporting data on NPLs from AMCs.
} 
increasing consumer-related loans while being more active in risk management and monitoring of loans made to SOEs. For example, the ratio of consumer lending to total loans outstanding made from all banks increased from 1\% in 1998 to 12\% in 2008; by the third quarter of 2009, RMB 4.99 trillion (or $\$ 730.4$ billion) of outstanding bank loans were extended to consumers. The size of housing mortgages, now the largest component (87\% as in the third quarter of 2009) of consumer credit, grew more than 200 times between 1997 and 2008, reaching a total of RMB 4.35 trillion (\$637.2 billion), although the speed of growth has slowed down in 2011, according to the China Quarterly Monetary Policy Report of the PBOC. One problem with the massive expansion of consumer credit is that China lacks a national consumer-credit database to spot overstretching debtors, although a pilot system linking seven cities was set up in late 2004. The deficiency in the knowledge and training of credit risk and diligence of loan officers from state-owned banks is another significant factor in credit expansion, which can lead to high default rates and a large amount of new NPLs if the growth of the economy and personal income slows down.

Accompanying the rapidly expanding automobile industry, the other fast growing category of individual-based loans is automobile loans, most of which are made by state-owned banks. The total balance of all China’s individual auto loans increased from RMB 400 million (\$50 million) in 1998 to RMB 200 billion ( $\$ 25$ billion) at the end of 2003, and as much as 30\% of all auto sales were financed by loans during this period (Financial Times, 05/25/2005). The growth in both auto sales and loans slowed down significantly since 2004 in part due to the high default rates. In 2008, outstanding auto loans decreased to RMB 158.3 billion (\$23 billion). Only 8\% of the auto sales were financed by loans during that year. Shanghai and Beijing have the largest number of car sales and loans. As many as $50 \%$ of debtors defaulted on their car loans in these cities. There are examples in which loan applications were approved based solely on the applicants' description of their personal income without any auditing (Barron's, 12/06/2004). However, the slowdown of the auto loan market was temporary and it quickly resumed its fast pace of growth, mainly driven by tremendous demand-China has recently overtaken the U.S. to become the largest auto market in the world. In aggregate auto loans amount to $10 \%-20 \%$ of the total amount spent on autos. Most loans mature in three to five years. ${ }^{16}$

Second, the ongoing privatization process, including the listing of state-owned banks, is also an effective channel for enhancing efficiency. As state ownerships stakes shrink, these banks can focus more on for-profit goals, and, with more non-state owners entering the mix the strengthening of

\footnotetext{
${ }^{16} \mathrm{~A}$ few foreign lenders (e.g., GM and Ford) were approved to enter China's auto loan market by forming joint ventures with Chinese automakers (Financial Times, 05/27/2005).
} 
corporate governance to ensure profit-maximizing is the next step. Panel A of Table 4-A presents the performance of IPOs of the Big Four banks (ABC remains in the State Sector) and that of the Bank of Communications (BComm). A notable case is the IPO of ICBC (see Allen, Qian, Shan and Zhao, 2012 for more details). Simultaneously carried out in the HKSE and SHSE on October 27, 2006, ICBC raised US\$21.9 billion, making it the largest IPO (up to that date). The first day (and first week cumulative) return, measured by the net percentage return of the closing price on the first (fifth) trading day over offer price, was almost 15\%, suggesting high demand for ICBC’s H shares among (foreign) investors. In terms of ownership structure, the state, through various agencies, is by far the largest shareholder, with only $22 \%$ of the market cap is 'free float' or tradable. The largest foreign shareholder is Goldman Sachs with its 5.8\% ownership stake negotiated before the IPO. The recent IPO of ABC also attracted a lot of attention. The total proceeds from its IPO from HKSE (July 16, 2010) and SHSE (July 15, 2010) reached \$22.1 billion, overtaking the ICBC IPO as the world's largest IPO (Associated Press, 08/16/2010). ${ }^{17}$ In particular, foreign investors, including institutional investors and wealthy families, contributed over $40 \%$ of the $\$ 12$ billion raised from $\mathrm{H}$ shares (in the HKSE). ${ }^{18}$ While the first-week stock performance in the two markets was not as impressive as that of ICBC, the fact that the IPO was carried out successfully during the recovery period following one of the worst global financial crises is evidence that investors from around the globe have confidence in ABC's role as a leading institution in the world.

The IPOs of the other three large state-owned banks were also successful in terms of total proceeds raised, and they all attracted significant foreign ownership at the IPO date as well. In fact, as shown in Panel B of Table 4-A, four of the 10 largest banks in the world, measured in market capitalization as of July 2010, are Chinese banks, with ICBC leading the chart and the newly listed ABC making it into the chart too. In terms of (book) assets, ICBC is the eleventh largest bank in the world (Panel C); however, given the accounting problems of evaluating troubled assets related to subprime loans and sovereign debt in troubled Euro Zone countries, it is possible that ICBC's assets, with virtually no exposure to the U.S. housing markets or European sovereign debt, could be one of the largest and highest quality in the world. Finally, Moody’s current ratings on these publicly listed

\footnotetext{
${ }^{17}$ From Panel A, Table 4A, the total proceeds (in HK\$ and RMB) of the ICBC IPO are actually larger than that of ABC's IPO, but given the appreciation of RMB over the period 2006-2010, the proceeds of the ABC IPO are slightly larger measured in US\$.

${ }^{18}$ Foreign institutional investors include Qatar Investment Authority (\$2.8 billion), Kuwait Investment Authority ( $\$ 800$ million), Britain's Standard Chartered Bank (\$500 million), Dutch bank Radobank Nederland (\$250 million), Australia's Seven Group Holdings Ltd (\$250 million) and Singapore's Temasek Holdings (\$200 million); source: ABC’s post-IPO news report. However, on a global basis, including shares that are distributed to various government agencies prior to the IPO, foreign investors only hold $4 \%$ of all of ABC's shares.
} 
banks (on both deposits and loans) range from A to Baa (highest rating is Aaa); while S\&P rates these banks' outstanding bonds between A and BBB (highest rating is AAA).

There are two imminent issues with the privatization process. The first is related to the structure of the banking sector, and in particular, whether more competition, including the entrance of more non-state (domestic and foreign) banks and intermediaries, is good for improving the efficiency of both the Big Four banks and the entire sector. ${ }^{19}$ Another issue is the government's dual role as regulator and as majority owner. These potentially conflicting roles can diminish the effectiveness of each of the two roles that the government intends to carry out. In Section IV below, we consider whether the ongoing process of floating non-tradable government shares in many listed companies can be applied to the privatization process of many state-owned banks/institutions. Only after these banks are (majority) owned by non-government entities and individuals can they unconditionally implement all profit- and efficiency-enhancing measures. However, in light of what occurred in the developed countries, where excessive risk-taking and poor risk management and governance in a few large institutions essentially brought down the entire financial system, the current ownership structure of the largest Chinese banks, in which the government retains the majority control, can enhance the regulation of large financial institutions and help to prevent banking and financial crisis in China and other emerging economies.

Third, reforming the organization structure of banks and providing more incentives to banks and their employees can improve efficiency. For example, reforms taking place in the mid-1990s provided local banks with more autonomous power, and after the 1994 reforms, approved credit volume for specialized banks was based on a maximum ratio between loans and deposits instead of administrative quota, which provided those banks with greater flexibility to use within-bank transfers to adjust fund allocation. ${ }^{20}$ The reforms also provide more profit incentives for managers. The evaluation criteria changed from adherence to the national credit plan to "a combination of profits made by the bank branch, attention to cost control, investment in fixed capital of the branch, deposit increases, and reduction of overdue loans” (Park and Sehrt, 2001, p619).

A critical aspect of the decentralization process is to provide individuals with more authority and responsibilities. According to a number of theories (e.g., Stein, 2002), these changes improve the quality of 'soft' information produced by banks, an essential part of the lending process. Under the

\footnotetext{
${ }^{19}$ For example, with a sample of both state- and non-state owned banks, Berger et al. (2009) show that the addition of foreign ownership stakes into banks' ownership structure is associated with a significant improvement of bank efficiency. ${ }^{20}$ These reforms did not liberalize interest rates; the PBOC continues to set the range (upper and lower bounds, or base rate and floating range) within which interest rates can be set; relending was also centralized by the PBOC.
} 
old regime, decision making of the entire lending process was group-based and no individual loan officers were held responsible for poor decisions. Facing imminent pressure from competitors (including foreign banks) following China’s entrance to WTO in 2001, many state-owned banks began implementing new lending policies in 2002. These new policies grant more authority to individuals in charge of different steps of making loans and monitoring borrowers and hold them responsible (ex post) for poor performance; decisions such as the final approval of loan contracts are left to a group of senior employees (through voting). Using detailed loan-level data from a large state-owned bank with branches throughout the country, Qian, Strahan and Yang (2011) find that an internal risk assessment measure has a more pronounced effect, relative to publicly available information ('hard' information), on both pricing (interest rates) and nonpricing terms (loan size) of loan contracts after the reform and becomes a better predictor of loan outcomes. They also show that when the loan officer and the branch president who approves the loan contract work together for a longer period of time, the rating has an incrementally stronger effect on loan contracts. These results highlight how organizational structure and incentives can affect the production and quality of soft information. Better information, in turn, expands the supply of credit and improves (lending) outcomes.

One problem that hinders banks’ efforts in improving efficiency is poor and inconsistent enforcement of bankruptcy laws and creditor protection. China's first bankruptcy law, passed in 1986, governed only SOEs and had little impact in practice. The new bankruptcy law, enacted in August 2006 and effective on June 1, 2007, applies to all enterprises except partnerships and sole proprietorships. In many aspects the new law resembles bankruptcy laws in developed countries. For example, it introduces the bankruptcy administrator, who manages the assets of the debtor after the court has accepted the bankruptcy filing. Moreover, the law states that these administrators should be independent professionals, such as those working for law or accounting firms. Despite all the legal procedures specified by the law, enforcement of the law remains weak and inconsistent. Many distressed and insolvent firms are kept afloat, and almost all the listed firms that file for bankruptcy end up with restructuring plans and these firms are rarely delisted. ${ }^{21}$

A number of reasons can explain the weak enforcement of the bankruptcy law. There are regulations and circulars issued by the central government applicable to SOE bankruptcies that are de

\footnotetext{
${ }^{21}$ According to the National Development and Reform Commission, 67,000 small and mid-sized enterprises were shut down in the first half of 2008, but only 2,955 bankruptcy cases were filed nationwide for the same year. When a listed firm is in distress (with the "ST" flag), typically other (nonlisted) firms will invest in and restructure the ST firm to avoid delisting, since the 'shell' of the distressed firm is valuable given the difficult and costly process of IPOs.
} 
facto in priority over the Law. A good example is Doctrine \#10 of the State Council, which governs the bankruptcy process of SOEs in 111 pilot cities. This doctrine requires approval from secured/senior creditors (e.g., banks) before an enterprise can go through bankruptcy proceedings. In reality, however, the bankruptcy court also requires the consent of local government (Fan et al., 2008). Since local governments are usually responsible for the settlement of workers displaced by bankrupt firms, it is in their best interest to halt the bankruptcy filing until a satisfactory settlement plan is reached. As a result, mergers and acquisitions with other firms are preferred to bankruptcy, and it has been documented that M\&As have been indeed used extensively to resolve firms’ distress (e.g., Kam et al., 2008), and many bankruptcies cases are postponed or avoided. In fact, when in distress, both the SOEs and local government give the greatest priority to employees; local government favors SOEs over banks since SOEs provide more employment opportunities. Furthermore, banks are often reluctant to push for bankruptcy since most of the distressed debt would be written off; the recovery rate for most bank loans is less than 10\% (World Bank, 2001). Taking the defaulted firm to court to recover loans or seize the firm’s assets is a lengthy process and the chances of winning are slim; as a result, only a small number of lawsuits involving bankrupt firms reach the courts.

For insolvent SOEs, what triggers the bankruptcy procedure is not their financial status per se, but whether they can get preferential treatment from the government. The average number of bankruptcy cases placed on file (by courts) was 277 per year during 1989-1993. This then jumped to 5,900 per year between 1994 and 2003, after the Capital Structure Optimization Program for industrial SOEs was implemented in several pilot cities. ${ }^{22}$ The number of cases fell after 2003 partly due to the central government's intention to maintain social stability by controlling the number of bankruptcies; the Supreme People’s Court also ruled in 2002 that the courts would not process bankruptcy cases if the main intention were to escape debts. According to the surveys presented by Garnaut, Song and Yao (2004), 90\% of CEOs of the surveyed SOEs believe that bankruptcy is actually a feasible channel to evade bank debts. Since the government’s program provides preferential treatments including debt write-offs, many SOEs would wait until they are covered by the program before filing for bankruptcy.

As the most senior creditors (secured debt), banks’ willingness to lend depends on their bargaining power and ability to seize collateralized assets upon default, and hence ineffective creditor protection not only increases potential losses from bad loans, it also reduces banks’ incentive to

\footnotetext{
${ }^{22}$ In China, a court must accept a case petition before deciding whether it should be declined or placed on file for investigation/prosecution; thus the number of cases accepted is always greater than the number of cases placed on file.
} 
investigate and monitor borrowers. ${ }^{23}$ The favorable treatment SOEs enjoy during distress adversely change their incentives in investment and corporate governance, these effects can also spill over into banks' decisions to lend to non-state firms and reduce the credit access of these firms. Therefore, consistent regulation guidelines in dealing with distress and bankruptcy by different types of firms, along with the government's commitment to leave the decision process to professionals and courts, can benefit the development of credit markets. On the other hand, we discuss evidence below that informal dispute resolution mechanisms outside the legal system based on reputation and relationships has been an effective substitute for Chinese firms and investors.

\section{III.3 Growth of Non-state Financial Intermediaries}

The development of both non-state banks and other (state and non-state) financial institutions will allow China to have a stable and functioning banking system in the future. In addition to boosting the overall efficiency of the banking system, these financial institutions provide funding to support the growth of the Hybrid Sector.

First, we examine and compare China's insurance market to other Asian economies (South Korea, Taiwan, and Singapore). In terms of the ratio of total assets managed by insurance companies over GDP (Figure 2-C), China's insurance market is significantly smaller than that of other economies. At the end of 2009 total assets managed are only about 10\% of GDP, while this ratio for the other three economies is over $30 \%$. It is clear that the insurance industry is also significantly smaller compared to China's banking industry, and property insurance is particularly underdeveloped due to the fact that the private real estate market was only recently established (in the past most housing was allocated by employers or the government). Despite the fast growth of insurance coverage and premium income, only $4 \%$ of the total population was covered by life insurance. Insurance premiums were only $3.2 \%$ of GDP in 2008, standing far behind the global average figure of over 7\%; coverage ratios for property insurance are even lower (according to the reports by KPMG, LLP). However, coverage ratios have been growing steadily at an average annual rate of $6 \%$ between 1998 and 2005 (XinHua News). In 2008 the insurance industry in China grew at the fastest pace (40\%) since 2002. In the first quarter of 2010, China Insurance Regulatory Committee announced that China’s insurance premiums totaled RMB 454.14 billion, representing an increase of 38.6 percent year on year.

\footnotetext{
${ }^{23}$ With a large sample of syndicated loans around the globe, Qian and Strahan (2007) show that strong creditor protection (in borrower countries) enhances loan availability as lenders are more willing to provide credit on favorable terms (e.g., longer maturities and lower interest rates).
} 


\section{Insert Tables 4-B and 4-C, and Figure 2-C here.}

Table 4-B provides a (partial) breakdown of the different types of banks. During the period of 2001-2009, although the largest four or five banks (the fifth largest bank is Bank of Communications, also state owned) dominate in every aspect of the banking sector, the role of other banks in the entire banking sector cannot be ignored. As of 2009, other banks (including foreign banks) and credit cooperatives' total assets compose over $70 \%$ of the largest five banks (the actual fraction is likely to be higher due to incomplete information on all types of deposit-taking institutions); similar comparisons can be made for total deposits and outstanding loans. In addition, these banks and institutions appear to have less NPLs than the largest state-owned banks. Table 4-C provides evidence on the growth of non-bank intermediaries. Overall, the growth of these non-bank intermediaries has been impressive since the late 1990s. Among them, "other commercial banks" (many of them are state-owned), RCCs, and TICs hold the largest amount of assets; the size of foreign banks and mutual funds (not listed in the table) is minuscule, but these are likely to be the focus of development in the near future. ${ }^{24}$ Finally, our coverage of non-bank financial institutions excludes various forms of informal financial intermediaries, some of which are deemed illegal but overall provide a considerable amount of financing to firms in the Hybrid Sector.

\section{Financial Markets}

In this section, we examine China's financial markets, including both the stock and real estate markets, and the recent addition of venture capital and private equity markets as well as asset management industries. We also compare, at the aggregate level, how firms raise funds in China and in other emerging economies through external markets in order to determine if China's experience is unique. We then briefly review publicly traded companies’ financing and investment decisions. Finally, we discuss the further development of financial markets as well as corporate governance and the performance of listed firms.

\section{IV.1 Overview of Stock Markets}

After the inception of China's domestic stock exchanges, the SHSE and SZSE, in 1990, they initially grew quickly. The high growth rates continued through most of the 1990s, and the market reached a peak by the end of 2000. As shown in Figure 3, the momentum of the market, indicated by the SSE Index, then reversed during the next five years as it went through a major correction with

\footnotetext{
${ }^{24}$ Postal savings (deposit-taking institutions affiliated with local post offices) is another form of non-bank intermediation that is not reported in Table 4-B due to a lack of time series data. However, at the end of 2008, total deposits within the postal savings system exceeded RMB 2079 billion, or 9.5\% of all deposits in China.
} 
half of the market capitalization lost. Most of the losses were recovered by the end of 2006, and the market reached new heights during 2007. However, following a string of negative news worldwide (culminating with the subprime loans-led global crisis) and domestically (including high levels of inflation) the market lost three quarters of its value by the end of 2008. During the first half of 2009, with the impact of the massive stimulus package and rebounding from a trough, China's stock market bounced back and recovered about one third of the losses in 2008. However the stock market dipped again in the first half of 2010, partly due to the concern that the government is taking measures to cool down the fast growing housing market. Figure 3 compares the performance of some of the major stock exchanges around the world, as measured by the 'buy-and-hold' return in the period December 1992 and December 2010 (gross return at December 2010 with \$1 invested in each of the valued-weighted stock indexes at the end of 1992). We plot inflation-adjusted real returns. Over this period, the performance of the value-weighted SHSE index (the calculation for the SZSE is very similar) is below that of the SENSEX (India), which has the best performance among the group, and that of S\&P (U.S.), but better than FTSE (London) and the Nikkei Index, the worst among the group.

\section{Insert Figure 3 and Table 5-A here.}

As Table 5-A indicated, at the end of 2010, the SHSE was ranked the sixth largest market in the world in term of market capitalization, while the SZSE was ranked the fourteenth. The Hong Kong Stock Exchange (HKSE), where selected firms from Mainland China have been listed and traded, is ranked the seventh largest in the world. Needless to say, the Chinese financial markets will play an increasingly important role in world financial markets. Also from Table 5-A, "Concentration” is the fraction of total turnover of an exchange within a year coming from the turnover of the companies with the largest market cap (top 5\%), and SHSE (55.8\%) is in line with that of other large exchanges, indicating that trading is concentrated among large-cap stocks. "Turnover velocity” is the (annual) total turnover for all the listed firms expressed as a percentage of the total market capitalization, and the figures for SZSE and SHSZ are the highest among the largest exchanges, suggesting that there is a large amount of speculative trading especially among small- and mediumcap stocks (as these are more easily manipulated than large cap stocks) in the Chinese markets.

There are two other markets established to complement the two main exchanges. First, a fully electronically operated market (“Er Ban Shi Chang” or "Second-tier Market," similar to the NASDAQ) for Small and Medium Enterprises (SMEs) was opened in June 2004. It was designed to lower the entry barriers for SME firms, especially newly established firms in the high-tech industries. By the end of February 2007, there are 119 firms listed in this market. Second, a "third-tier market” 
(“San Ban Shi Chang,” or “Third-tier Market,”) was established to deal primarily with de-listing firms and other over-the-Counter (OTC) transactions. Since 2001, some publicly listed firms on both SHSE and SZSE that do not meet the listing standards have been delisted and the trading of their shares shifted to this market. On October 23, 2009, China launched a Nasdaq-style Growth Enterprises Market (GEM, or “Chuang Ye Ban”) with 28 companies, mainly from hi-tech, electronic and pharmaceutical industries. The main purpose of GEM is to provide financing for small and medium sized private enterprises. The first 10 firms seeking to list on the GEM drew a combined RMB 784 billion in subscriptions in September 2009, while the second and third sets had 18 firms, including Huayi Brothers Media, China’s largest privately owned film company. As of October 2011, no index is available for the GEM but most of the listed stocks have outperformed the indexes of the two main exchanges. By April 2010, the number of listed firms on the GEM reached 200.

There is abundant evidence showing that China's stock markets are not efficient in that prices and investors' behavior are not necessarily driven by fundamental values of listed firms. For example, Morck et al. (2000) find that stock prices are more 'synchronous” (stock prices move up and down together) in emerging countries including China than in developed countries. They attribute this phenomenon to poor minority investor protection and imperfect regulation of markets in emerging markets. In addition, there have been numerous lawsuits against insider trading and manipulation (see, e.g., AQQ (2008), for more details). In many cases, unlike Enron and other well known companies in developed markets stricken by corporate scandals, managers and other insiders from the Chinese companies did not use any sophisticated accounting and finance maneuvers to hide their losses (even by China's standards). These cases reveal that the inefficiencies in the Chinese stock markets can be (partially) attributed to poor and ineffective regulation. We discuss below issues related to regulation, market efficiency, and the further development of China's financial markets.

\section{IV.2 Overview of Bond Markets}

Table 5-B provides information on China's bond markets. The government bond market had an annual growth rate of $25.3 \%$ during the period 1990-2009 in terms of newly issued bonds, while total outstanding bonds reached RMB 4,976.8 billion (or $\$ 721.3$ billion) at the end of $2008 .{ }^{25}$ The second largest component of the bond market is called "policy financial bonds" (total outstanding amount RMB 3,668.6 billion (or $\$ 531.7$ billion) at the end of 2008. These bonds are issued by

\footnotetext{
${ }^{25}$ On July 26, 2007, Moody's raised the rating on China's government bonds to A1 from A2 and kept it unchanged up to now. In November 2009 it raised China's sovereign rating outlook from stable to positive. These ratings are better or comparable than Moody's ratings on government bonds from most emerging economies.
} 
“policy banks," which operate under the supervision of the Ministry of Finance, and the proceeds of bond issuance are invested in government run projects and industries such as infrastructure construction (similar to municipal bonds in the U.S.). Compared to government-issued bonds, the size of the corporate bond market is small. In terms of the amount of outstanding bonds at the end of 2008, the corporate bond market is less than one-fourth of the size of the government bond market. However, the growth of the corporate bond market has picked up pace in the past few years and this trend is likely to continue in the near future.

\section{Insert Table 5-B here.}

The small size of the bond market, especially the corporate bond market, relative to the stock market, is common among Asian countries. AQQ (2008) compares different components (bank loans to the private sectors or the Hybrid Sector of China; stock market capitalization; public/government and private/corporate bond markets) of the financial markets around the world at the end of 2003. Compared to Europe and the U.S., they find that the size of both the government (public) and corporate (private) bond markets is smaller in Asia excluding Japan (Hong Kong, South Korea, Malaysia, Taiwan, Singapore, Indonesia, Philippines, and Thailand); even in Japan, the size of the corporate bond market is much smaller compared with its government bond market. They also find that the size of all four components of China's financial markets are small relative to that of other regions and countries, including bank loans made to the Hybrid Sector (private sector) in China (other countries). Moreover, the most under-developed component of China's financial markets is the corporate bond market (labeled “private” bond market).

There are a number of reasons for the underdevelopment in bond markets in China and other parts of Asia (see, e.g., Herring and Chatusripitak 2000). Lack of sound accounting/auditing systems and high-quality bond-rating agencies is a factor. ${ }^{26}$ Given low creditor protection and court inefficiency (in China and most other emerging economies) the recovery rates for bondholders during default are low, which in turn leads to underinvestment in the market (by domestic and foreign investors). Lack of a well constructed yield curve is another factor in China, given the small size of the publicly traded Treasury bond market and lack of historical prices. The situation is improving however, as the terms of China’s Treasury bonds now ranges from one month to 30 years. In December 2009, China’s first 50-year government bond made its trading debut simultaneously in the interbank market and the stock exchange bond market, extending the bond yield curve even further.

\footnotetext{
${ }^{26}$ Dagong Global Credit Ratings, a leading Chinese credit ratings agency, recently released its first sovereign ratings report, in which the Chinese and German sovereign debt received higher ratings (AA+ and a stable outlook) than those of US, the UK and Japan (AA or lower ratings and a negative outlook; Bloomberg, 7/14/2010).
} 
The deficiencies in the term structure of interest rates have hampered the development of derivatives markets that enable firms and investors to manage risk, as well as the effectiveness of the government's macroeconomic policies. Therefore, further development of China's bond markets, along with its legal system and related institutions, can help the advancement of other markets and the overall financial system.

\section{IV.3 Evidence on the Listed Sector}

In this section, we briefly examine publicly listed and traded companies in China. It is worthwhile to first clarify whether firms from the Hybrid Sector can become listed and publicly traded. Regulations and laws (the 1986 trial version of the bankruptcy law and the 1999 version of the Company Law) did not prohibit the listing of Hybrid Sector firms; and selected firms from the Hybrid Sector did enter the Listed Sector through an IPO or acquisition of a listed firm from the inception of SHSE and SZSE. However, the accessibility of equity markets for these firms has been much lower than for former SOEs in practice due to the enforcement of the listing standards and process. As a result, AQQ (2005) find that $80 \%$ of their sample of more than 1,100 listed firms are converted from former SOEs. In recent years, the government has attempted to change the composition of listed firms by relaxing regulations toward Hybrid Sector firms, including the establishment of the recently opened GEM.

Until the recent share reform, which is discussed further below, listed firms in China issued both tradable and nontradable shares (Table 6-A). The nontradable shares were either held by the government or by other state-owned legal entities (i.e., other listed or non-listed firms or organizations). Table 6-B shows that, as of the end of 2009, nontradable shares constituted around half of all shares (53\%, column 2) and the majority of tradable shares were A shares. Among the tradable shares, Class A and B shares are listed and traded in either the SHSE or SZSE, while Class A (B) shares are issued to and traded by Chinese investors (foreign investors including those from Taiwan and Hong Kong and QFIIs). While the two share classes issued by the same firm are identical in terms of shareholder rights (e.g., voting and dividend), B shares were traded at a significant discount relative to A shares and are traded less frequently than A shares. ${ }^{27}$ The "B share discount” has been reduced significantly since the CSRC allowed Chinese citizens to invest and trade B shares (with foreign currency accounts) in 2001. In addition, Class H shares, issued by selected

\footnotetext{
${ }^{27}$ Explanations of the B share discount include: 1) Foreign investors face higher information asymmetry than domestic investors, 2) lower B share prices compensate for the lack of liquidity (due to low trading volume), and 3) the A share premium reflects a speculative bubble component among domestic investors. See, e.g., Chan, Menkveld, and Yang (2008) and Mei, Scheinkman, and Xiong (2003) for more details.
} 
"Red Chip” Chinese companies, are listed and traded on the HKSE. Finally, there are N shares and S shares for firms listed in the U.S. and Singapore but operate in China (we omit discussions on these shares since they are not listed on the domestic exchanges). After the share reforms discussed below in Section IV.7, government shares became G shares and are tradable.

\section{Insert Tables 6-A and 6-B here.}

We next describe standard corporate governance mechanisms in the Listed Sector. First, according to the (2005) Company Law, listed firms in China have a two-tier board structure: the Board of Directors (five to nineteen members) and the Board of Supervisors (at least three members), with supervisors ranking above directors. The main duty of the Board of Supervisors is to monitor firms' operations as well as top managers and directors; it consists of representatives of shareholders and employees, with the rest either officials chosen from government branches or executives from the parent companies; directors and top managers of the firms cannot hold positions as supervisors. The company has the discretion to decide the number of representatives of employees on the Board of Supervisors, but representatives of employees must account for at least one third of the board. The Board of Directors serves similar duties as their counterparts in the U.S., including appointing and firing CEOs. According to the "one-share, one-vote" scheme adopted by firms in the Listed Sector, shareholders including the state and legal person shareholders (that typically own the majority of shares) appoint the board members. Specifically, the Chairman (one person) and Vice Chairman (one or two) of the Board are elected by all directors (majority votes); at the approval of the Board, the CEO and other top managers can become members of the Board. The CSRC requires at least one third (and a minimum of two people) of the Board to be independent.

Since the Law does not specify that every member of the Board must be elected by shareholders during general shareholder meetings, in practice some directors are nominated and appointed by the firms’ parent companies and the nomination process is usually kept secret, in particular for former SOEs. Since not all members of either board are elected by shareholders, a major problem with the board structure is the appointment of and contracting with the CEOs. Based on firm-level compensation data (available since 1998 due to disclosure requirements), Fung et al. (2003) and Kato and Long (2004) find that no listed firms grant stock options to CEOs or board members. The situation is somewhat different now. Among overseas listed SOEs, barriers to exercising stock options have been overcome, and some senior executives have been granted stock options (examples include the former chairman of CNOOC Wei Liucheng and Bank of China-Hong Kong former chairman Liu Mingkang) and received substantial rewards (Caijing Magazine, 2008). 
However, the cash-based compensation level for CEOs is still much lower than their counterparts in developed countries, and the consumption of perks, such as company cars, is prevalent.

Second, the existing ownership structure, characterized by the large amount of non-tradable shares including cross-holdings of shares among listed companies and institutions, makes it difficult for value-increasing M\&As. According to the China Venture Source, there were 2,656 M\&A deals involving listed firms in 2010 totaling US\$169.6 billion, a small fraction of the total market capitalization. In many deals, a Hybrid Sector firm (non-listed) acquires a listed firm that is converted from an SOE, but the large amount of non-tradable shares held by the state remain intact after the transaction. ${ }^{28}$ Such an acquisition can be the means through which low quality, non-listed companies bypass listing standards and access financial markets (e.g., Du et al., 2008).

Third, one factor contributing to the occurrence of corporate scandals is the lack of institutional investors (including non-depository financial intermediaries) as they are a very recent addition to the set of financial institutions in China. Professional investors would perhaps not be so easily taken in by simple deceptions. Another factor is that the enforcement of laws is questionable due to the lack of legal professionals and institutions.

Fourth, the government plays the dual roles of regulator and blockholder for many listed firms, including banks and financial services companies. The main role of the CSRC (counterpart of the SEC in the U.S.) is to monitor and regulate stock exchanges and listed companies. The government exercises its shareholder control rights in listed firms through the Bureau of National Assets Management, which holds large fractions of nontradable shares, or other SOEs (with their holdings of nontradable shares). However, since the senior managers of the Bureau are government officials, it is doubtful that they will pursue their fiduciary role as controlling shareholders diligently, since their compensation is probably not incentive-based; even if their compensation was tied to performance, they may lack the expertise to make the correct strategic decisions. Moreover, the government's dual roles can lead to conflicting goals (maximizing profits as shareholder vs. maximizing social welfare as regulator or social planner) in dealing with listed firms, which in turn weaken the effectiveness of both of its roles. $^{29}$ There are cases in which the government, aiming to achieve certain social goals, influenced the markets through state-owned institutional investors (e.g., asset management companies)

\footnotetext{
${ }^{28}$ If we include the cross-border M\&As and transactions between parent companies and subsidiaries, the total amount increases to US $\$ 47$ billion in 2000, $\$ 14$ billion in 2001, \$29 billion in 2002, and \$24 billion in the first three quarters of 2003. 68\% of all M\&A deals (66\% in terms of dollar deal amount) are initiated by Hybrid Sector firms, while former SOEs and foreign firms initiate $29 \%$ and $3 \%$ of the rest, respectively ( $27 \%$ and $7 \%$ in deal amount). M\&As are most active in coastal regions, and in industries such as machinery, information technology, retail, and gas and oil.

${ }^{29}$ See Pistor (2010) for a description of the complicated relationships among various regulatory agencies and the central government branches, and how these relationships affect the decision-making process of regulations and enforcement.
} 
but created unintended adverse effects. Based on a sample of 625 firms with $28 \%$ of the CEOs being ex- or current government bureaucrats, Fan et al. (2007) find that the three-year post-IPO average stock returns of the sample underperform the market by $20 \%$, and the underperformance of firms with such politically-connected CEOs exceeds those without politically-connected CEOs by almost 30\%. Firms with politically-connected CEOs are also more likely to appoint other bureaucrats but not personnel with relevant professional to boards of directors.

Overall, internal and external governance for the Listed Sector is weak, and further development of governance mechanisms is likely in this sector going forward. In Section IV.7 below we further discuss this issue..

\section{IV.4 Real Estate Market}

Like other economic sectors, China's real estate market has long been operating under the ‘dual tracks’ of both central planning and market-oriented systems. Prior to 1998, government control was dominant with the market only playing a secondary role, and mortgages were not designated for retail customers and households. Chinese citizens working for the government and government owned companies and organizations could purchase properties at prices significantly below market prices, with the subsidies coming from their employers. The reform policies introduced in 1998 aimed to end the distribution of properties by employers and establish new housing finance and market systems. Provinces and autonomous regions have established programs to sell properties (e.g., apartments in urban areas) to individuals instead of allocating residency as part of the employment benefits.

Since 1998 the residential housing reform and the development of individual mortgages, along with rising household income and demand for quality housing, had stimulated the fast growth of the real estate market. Figure 4-A shows the total real estate investments and their funding sources over time. Total investment increased from RMB 321 billion in 1996, 12\% of the national fixed assets investments, to RMB 4.8 trillion in 2010 and 20\% of the national fixed assets investment. Most of the investment funds have come from domestic sources. Not surprisingly, bank loans are the most important source of real estate financing. China’s continuing economic growth especially in private sectors, urbanization and industrialization, limited land supply, increasing foreign direct investments and institutional investments, will further enhance the liquidity and long-term prospects of China's real estate assets.

As the real estate sector gained more weight in the economy, its impact on other industries, especially the financial and banking industries, increased considerably. With the expansion of the 
real estate market, banks and other financial institutions lent more to keep up with the demand for financing. When the fast expansion, in part fueled by the inflows of speculative capital and agency problems in investment, could not be sustained, increased demand led to hikes in property prices andreal estate bubbles surfaced. The bursting of such bubbles can lead to painful consequences in the entire economy.

\section{Insert Figures 4-A, 4-B and 4-C here.}

The real estate prices in major cities have risen sharply in recent years, and whether these fast growing prices are 'bubbles' and how to cool down the markets are among the most closely watched and hotly debated issues in China. We provide some simple analysis here; for a more thorough and careful analysis see, e.g., Wu, Gyourko, and Deng (2011). Figure 4-B shows the trends of total housing space developed vs. total space sold over the period 2002-2009 for the entire nation, and Figure 4-C compares the growth rates of total housing space developed vs. total space sold; actual space is normalized so that both charts begin at 100 in 2002; hence the vertical axis measures growth rates. We can see that while total space developed and total space sold (for both residential and nonresidential properties) grew at similar rates over the period (Figure 4-C), the gap between total space developed and sold — a proxy for the inventory of housing supply in the markets—widened from around 0.6 billion square meters in 2002 to 2.2 billion square meters in 2009.

In Figures 5-A through 5-E we plot and compare growth rates of average housing prices and disposable household income, over the period 2002-2009, for the nation and the four major cities: Beijing, Shanghai, Shenzhen and Guangzhou. Once again, actual housing prices (RMB per square meter) and disposable income are normalized so that both charts begin at 100 in 2002; hence the vertical axis measures growth rates and all the figures for prices and income are inflation adjusted. Steady growth of disposable income in line with rising housing prices can help sustain the growth of the housing markets, and hence considerable and increasing gaps in the growth rates reflect potential bubbles in the housing markets. Based on the figures it appears that while at the national level and in the city of Guangzhou there are no signs of bubbles, the opposite can be said for the large regional markets in Beijing, Shanghai and Shenzhen, where housing prices are rising at much higher paces than those of real disposable income in recent years. Shenzhen presents the most worrisome case, where despite fast-rising housing prices fueled by the inflow of speculative capital, real household income actually declined in 2008 and 2009 (from 2007 levels), perhaps (partially) due to the adverse effects of the global financial crisis on the exporting sectors, which rely mainly on migrant workers from other regions. 


\section{Insert Figures 5-A, 5-B, 5-C, 5-D, and 5-E here.}

We would like to emphasize again that our results are based on simple measures; however, analyses from Wu et al. (2011), who use more sophisticated metrics and regressions controlling for other factors that may affect housing prices, yield similar results that there may well be bubbles in the regional markets of Beijing, Shanghai and Shenzhen. There is some evidence that speculative foreign capital (the "hot money") flowing into China is partially responsible for the accelerated rise in real estate markets (e.g., Chu and Sing, 2004; Guo and Huang, 2010). Given the rising status of the Chinese economy and its currency, coupled with the weakening of the U.S. economy (and other developed countries), the dollar and near-zero interest rates in most developed countries, the inflow of 'hot money' into China’s real estate markets (and other sectors) may continue.

The government has been taking aggressive measures to control property prices. Since 2004, it has issued new policies in order to suppress speculative activities; another policy measure to control the growth of the real estate market is through the PBOC's required reserve deposit ratio. In 2010 and 2011, in response to the fast rising housing prices, the government has announced a series of interventions including: (a) increased equity down payment shares from $20 \%$ to $30 \%$ for first homes of more than 90 square meters in size; (b) increased equity down payment shares from $40 \%$ to $50 \%$ for second homes; (c) general discouragement of the use of any leverage on third homes or by external buyers (i.e., those not living in the market of the intended purchase); (d) new rules to prevent developers from hoarding housing units; (e) preparation of the introduction of a local property tax, with possible pilot implementations in Chongqing, a large city in the southwestern region that is under direct control of the central government, within the next one to two years; and (f) direct administrative orders on how much land and units of buildings can be developed. ${ }^{30}$ Among these measures, the proposed property tax may play a significant role in cooling down the markets, because it would raise the cost of carry on speculative investments in owner-occupied housing.

Despite the government's macroprudential policies in recent years and the newly announced measures and strong signals in recent months, the impact of these measures on the housing markets seems to be limited. One reason, as stipulated by many observers, is that since various government agencies and officials have played a major role in developing 'commercial properties' it is not in their best interest to see major market corrections. The evidence in Wu et al. (2011) provides some support of this view. They find that much of the increase in housing prices is occurring in land

\footnotetext{
${ }^{30}$ For more details, see "Gazette of Executive Meeting of the State Council," December 14th, 2009; and "Circular of the State Council on Resolutely Containing the Precipitous Rise of Housing Prices in Some Cities” (Decree No. [2010] 10), April 17th, 2010, and Wu et al. (2011).
} 
values. Using land auctions data from Beijing, they also find SOEs controlled by the central government paid 27\% more than other bidders for an otherwise equivalent land parcel. Since many vested government officials have a lot to lose following a crash in the real estate markets, it is argued that the new measures, including the proposed property taxes, will not be effectively enforced; such a belief can also explain why speculative capital continues to enter the housing markets.

Given the experiences of many other countries in the recent and previous financial crises, the government's efforts in controlling the rise of housing markets in the aforementioned regions, and preventing this spreading to other regions of the country can augment its other efforts in stabilizing the economy and alleviating social tensions. In Section VI below we further examine how the inflow of speculative capital and subsequent outflow can create bubbles in the markets and then the bursting of the bubbles can spread to other sectors of the economy.

\section{IV.5 Private Equity/Venture Capital and the Funding of New Industries}

Allen and Gale (1999, 2000a) have suggested that stock market-based economies, such as the U.K. in the $19^{\text {th }}$ century and the U.S. in the $20^{\text {th }}$ century, have been more successful in developing new industries than intermediary-based economies such as Germany and Japan. They argue that markets are better than banks for funding new industries, because evaluation of these industries based on experience is difficult, and there is wide diversity of opinion. Stock market-based economies such as the U.S. and U.K. also tend to have well-developed systems for the acquisition and distribution of information, so the cost of information to investors is low. Markets then work well because investors can gather information at low costs and those that anticipate high profits can provide the finance to the firms operating in the new industries.

A key part of this process is the private equity/venture capital sector (see, e.g., Kortum and Lerner 2000). Venture capitalists are able to raise large amounts of funds in the U.S. because of the prospect that successful firms will be able to undertake an IPO. With data from 21 countries, Jeng and Wells (2000) find that venture capital is less important in other countries, while the existence of an active IPO market is the critical determinant of the importance of venture capital in a country. This is consistent with the finding of Black and Gilson (1998) in a comparison of the U.S. and Germany, that the primary reason venture capital is relatively successful in the U.S. is the active IPO market that exists there.

These facts imply that the development of active venture capital and private equity markets can increase the financing for China's new industries. What is unusual about China (perhaps along 
with India) is that it currently has the ability to develop both traditional industries, such as

manufacturing, and in the near future new, high-tech industries, such as aerospace, computer software, semiconductors, and bio-genetics. This is different from the experience of South Korea and Taiwan in the 1970s and that of most other emerging economies in the 1990s, as all these other countries focused on developing manufacturing industries first. In terms of developing traditional industries (e.g., Korea and Taiwan in the 1970s), China has already followed suit in first introducing advanced (relative to domestic companies) but not the most advanced technologies from developed countries; and "nationalizing" these technologies within designated companies before moving toward the more advanced technologies. Allen and Gale (1999, 2000a) argue that banks are better than financial markets for funding mature industries because there is wide agreement on how they are best managed, so the delegation of the investment decision to a bank works well. This delegation process, and the economies of scale in information acquisition through delegation, makes bank-based systems more efficient in terms of financing the growth in these industries. Therefore, the banking system can contribute more in supporting the growth and development of these industries than markets.

\section{IV.6 Asset Management Industries}

The mutual fund industry in China has gone through three stages of development. The first stage is between 1992, when China's first fund ( $L i u B o$ ) was established, and 1997, when the first version of the mutual fund regulation was drafted and passed by the CSRC. The LiuBo Fund was a closed-end fund with NAV RMB100 million RMB (\$12.5 million) and began to trade on the SHSE in 1993. While the industry experienced fast growth in the few years after 1992, lack of regulation and problems associated with fund trading hampered the further development of the industry. The first open-end fund was established in September, 2001 (Hua An Chuangxin), following the announcement of the proposal for open-end fund investment by the CSRC, a milestone for China's mutual fund industry.

Figure 6 shows the development of the mutual fund industry in China. With only a handful of funds in 1998, China now has sixty-five fund companies managing 551 different funds as of November 2009. The total net assets value increased from RMB11 billion (or \$1.3 Billion) in 1998 to about RMB 2.26 trillion (or \$328 billion) in November 2009 (this figure was much higher in the second half of 2007 before the markets went south). In 2001, the NAV of all funds was about $0.8 \%$ of GDP and $1.19 \%$ of total national savings; these figures rose to $6.16 \%$ of GDP and $8.58 \%$ of total savings in 2008. The growth of open-end funds contributed to most of the growth in the industry. As 
of November 2009, 520 funds are open-ended and 31 are close-ended, with 96\% of the total fund value managed by open-end funds. The most popular investment style is actively managed (domestic) equity, with only a few index funds and ETFs (exchange traded funds).

\section{Insert Figure 6 here.}

Many mutual fund companies are owned by securities and other financial services companies. Like their counterparts in the U.S., management fees are the major source of income for fund companies, accounting for about $80 \%$ of total income. Administration fees account for $9 \%$ of total income, and the rest of the income comes from investment and other incomes. More than half of the fund managers have a master-level or higher academic degree, and the majority of them are 36 to 45 years old. Investment capital from institutional investors is about the same as that from individual investors in 2005, but in 2006 individual investors account for 70\% of the total mutual fund investment. Among the 23 newly launched funds in the first half of 2009, individual investors account for $75.8 \%$.

The first fund managed by a qualified foreign institutional investor (QFII) was set up in 2002. The State Administration of Foreign Exchange (SAFE) is the government agent that regulates the QFII funds. The QFII Act allows foreign investors to invest in Chinese securities, with the intention of introducing sophisticated foreign investors to the Chinese market with the hope that their presence would improve market efficiency. In addition, with the exercise of their shareholder rights, their presence can also help improve corporate governance of the Listed Sector. However, the original QFII rules imposed restrictions on foreign investors, such as a capital lock-up period of one to three years limiting capital withdrawal (and leaving China) and other operating restrictions. In August 2006, CSRC revised QFII rules to promote more participation from foreign investors. Under the new rules, there has been a significant increase in applications from foreign investors for QFII quotas.

Most of the institutions in the first group of QFII applicants were securities companies and investment banks, with other financial services companies such as insurance companies and pension fund companies also on the list. By the end of July 2006, China had approved a total of \$7.495 billion foreign investment capital (quota) from 45 QFIIs, or three quarters of the then ceiling of \$10 billion capital inflow through QFIIs. In December 2007, the investment quota/ceiling tripled, from $\$ 10$ billion to $\$ 30$ billion. In September 2009, draft rules were issued by SAFE to increase the upward limit of investment for an individual QFII institution to \$1 billion from the previous $\$ 800$ million. Some analysts believe that the move to increase the QFII quota was also intended to prepare

for the large amount of floating of non-tradable shares. If the holders of the newly floated shares rush 
to sell, QFII funds can be a stabilizing source of the market. As of August 2011, there were a total of 116 approved QFIIs operating in China, of which 103 were investment funds. The approved investment quotas reached $\$ 20.69$ billion.

The approval of qualified domestic institutional investors (QDII) to invest in overseas markets came after QFII, in July 2006. The QDII funds invest in stocks, bonds, real estate investment trusts and other mainstream financial products in markets such as New York, London, Tokyo and Hong Kong. Similarly to the QFII scheme, it is a transitional arrangement that provides limited opportunities for domestic investors to access foreign markets at a stage in which a country/territory’s currency is not freely convertible and capital flows are restricted. As of early 2008, ten fund companies had obtained the approval to launch QDII. The total number of QDII funds reached 75 in July 2009. By April 2011, QDIIs had approved investment quotas of $\$ 72.67$ billion. Given the recent turmoil in the global financial markets, the performance of the QDII funds has been less than stellar. Going forward, the probable continuing appreciation of the RMB against major international currencies including the dollar is a major concern for QDII investors.

China's asset management industry is expected to continue its growth in the near future. In the U.S., mutual funds became the largest group of financial intermediaries in financial markets in 1999, holding 29\% of all financial assets. By contrast, mutual funds in China only held around 8.1\% of all financial assets as at the end of 2009. The further growth of the economy and continuing reform of the pension system will generate both demand and supply of capital for the industry. If the trend of opening up domestic markets to foreign investors continues, there will be a greater inflow of QFIIs.

\section{IV.7 Further Changes in Financial Markets}

As we have documented, the financial markets in China do not currently play nearly as important a role as banks. Going forward, further improvements in the operation of China's financial markets can help to promote the development of high-technology industries as discussed in Section IV.5. In addition, developing new financial products and markets can enhance the risk management capabilities of China's financial institutions and firms. Finally, deep and efficient markets can provide an alternative to banks for raising large amounts of capital.

In recent years the performance of the stock markets has been volatile. This is somewhat surprising given the robust performance of the real economy. We attribute this (relatively) poor performance to a number of factors including the following:

(i) Limited self-regulation and formal regulation. 
(ii) The large overhang of shares owned by government entities.

(iii) The lack of listed firms originating in the Hybrid Sector.

(iv) The lack of trained professionals.

(v) The lack of institutional investors.

(vi) Limited financial markets and products.

Efforts have been made to address some of these weaknesses. However, some of these are problems can only be tackled over the long run. We discuss each in turn.

\section{Regulations}

There are two ways in which markets are regulated in practice and each has advantages and disadvantages: first, market forces and self-regulation, and second, government regulation.

A good example of regulation through market forces and self-regulation is provided by the capital markets in the UK in the nineteenth and early twentieth century (Michie, 1987). The role of government regulation and intervention was minimal. Despite this the markets did extremely well and London became the financial capital of the world. Many firms and countries from all over the world raised large amounts of funds. Reputation and trust were an important factor in the smooth operation of these markets. For example, Franks et al. (2003) compare the early twentieth century capital markets with those in the mid-twentieth century. Despite extensive changes in the laws protecting minority shareholders there was very little change in the ways in which the market operated. The authors attribute this to the importance of trust.

We argue below that China's Hybrid sector is another example of a situation where market forces are effective. Formal regulation and legal protections do not play much of a role and yet financing and governance mechanisms are quite effective. In this case, as we shall see, it appears that competition as well as reputation and trust work well.

In contrast, the examples of fraud and other problems of manipulation and the inefficiency of markets pointed to in Section IV.1 suggest that in China's formal financial markets these alternative mechanisms do not work well. Although such mechanisms may develop in the long run as in the nineteenth and early twentieth century U.K., in the short run formal government regulation of the type introduced in the U.S. in the 1930s and subsequently as a response to the stock market collapse that started in 1929 and the Great Depression may allow Chinese markets to function better. There is evidence from many countries that this type of formal regulation is effective. For example, based on a study of securities laws with the focus on the public issuance of new equity in 49 countries (China 
is not included) LLS (2006) find that disclosure and liability rules help to promote stock market development.

\section{Sale of Government Shares in Listed Firms}

One of the major problems Chinese stock markets have faced in recent years has been caused by the large amount of shares in listed companies owned by the government and government entities shown in Table 6-B. The Chinese government attempted sales of state shares of selected firms in 1999 and 2001, but halted the process both times after share prices plunged and investors grew panicky about the value of the entire market. This overhang created great uncertainty about the quantity of shares that would come onto the market going forward. This uncertainty was probably in part responsible for the stagnation of share prices between 2002 and 2005 despite the very high levels of growth in the economy.

In 2005 the government announced a plan of "fully floating" state shares. Under the plan, the remaining state shares among listed firms were converted to “G” shares. The CSRC outlined the format for compensating existing shareholders and also imposed lockups and restrictions on the amount of $\mathrm{G}$ shares that could be sold immediately after they became tradable. More specifically, the plan stipulated that G shares were not to be traded or transferred within 12 months after the implementation of the share structure reform. Shareholders owning more than $5 \%$ of the original non-tradable shares can only trade less than $5 \%$ of the total shares outstanding within one year and less than $10 \%$ within 2 years. These restrictions of $\mathrm{G}$ share sales were intended to reduce the downward pressure on the stock price, maintain market stability and protect the interests of public investors. The details of the "fully floating plan" for a firm, including the number of G shares to be granted to each Class A shareholder and the time window (e.g., one to three years) of G shares become fully floating, had to be approved by two thirds of Class A shareholders of the firm.

Share reforms began with a pilot program with only four companies participating in April 2005. By the end of 2006, 96\% of all the listed companies had completed share reforms; by the end of 2007, there were only a few companies that had not reached an agreement with their shareholders on the terms of the reform. ${ }^{31}$ As documented in Table 6-B above, as of September 2009, for the first

\footnotetext{
${ }^{31}$ Hwang et al. (2006) document that share reform increases turnover, especially for firms with low liquidity prior to the reform, and reduces speculative trading. Although share prices drop significantly on the day of share supply increases, shareholder wealth increases by 15\% overall. Beltratti and Bortolotti (2006) document an $8 \%$ abnormal return around the date of share reform announcement. Liao and Liu (2008) show that market reactions to share reforms are positively associated with the quality of the listed firms (as measured by firm disclosure), providing evidence of improved market efficiency.
} 
time tradable shares accounted for more than half of the stock market, suggesting that the floating of nontradable shares is progressing.

Another fact worth mentioning is that for the firms that go public (IPOs) after the share reform, not all of their stocks are immediately floated to the market. Lock-up periods may still apply to large shareholders who obtained the shares before the IPO. For example, in the case of ABC's recent IPO, the majority of A shares (87.6\%) have already been distributed to various agencies of the government before the IPO. In fact, only 25.5 billions A shares (8.6\% of total outstanding A shares) were issued in the IPO. Those shares held by the government have a lock-up for 3 years. However, they are technically A (not G) shares. Thus no compensation will be paid when those shares become freely tradable.

\section{The Listing of Firms from the Hybrid Sector}

One of the major problems of the stock exchanges is that most of the firms listed are former SOEs. Relatively few are firms from the more dynamic Hybrid Sector. Reforming listing requirements and procedures to make it advantageous for dynamic and successful companies to become listed on the exchanges can enhance the overall quality of the Listed Sector. The establishment of the recently opened "GEM" provides an example in this regard.

\section{The Training of More Professionals}

This step will allowan improvement in the enforcement of laws and contracts. An independent and efficient judicial system requires a sufficient supply of qualified legal professionals. The Ministry of Justice of China states that there are 143,000 lawyers and 12,428 law firms as of 2007. Two hundred and six out of China’s 2,000 counties still do not have lawyers. Lawyers represent only $10 \%$ to $25 \%$ of all clients in civil and business cases, and even in criminal prosecutions, lawyers represent defendants in only half of the cases. Among the approximately five million business enterprises in China, only 4\% of them currently have regular legal advisers. Moreover, only one-fifth of all lawyers in China have law degrees, and even a lower fraction of judges have formally studied law at a university or college. As mentioned before, a similar situation exists for auditors and accounting professionals.

\section{Institutional Investors}

In most developed stock markets institutional investors, such as insurance companies, pension funds, mutual funds, and hedge funds, play an important role. They employ well-trained professionals who are able to evaluate companies well. This causes markets to have a higher degree of efficiency than if they are dominated by individual investors. In addition, there can be advantages 
in terms of corporate governance if institutional investors actively participate in the monitoring of firms’ managers and are directly involved in firms’ decision-making process as blockholders of stocks. For example, in the U.S., pension funds such as CALPERS have become the symbol of shareholder activism that strengthens corporate governance, while in Japan and Germany, financial intermediaries serve similar purposes. For China, the efficiency of China's stock markets as well as corporate governance of listed firms can be improved by further entry of domestic financial intermediaries that can act as institutional investors. With their large-scale capital and expertise in all relevant areas of business, financial intermediaries can provide a level of stability and professionalism that is sorely lacking in China’s financial markets.

Currently institutional investors such as insurance companies, mutual funds and pension funds are relatively small in terms of assets held given their early stage of development. However, they are expanding dramatically. Among policies that can further encourage the development of such intermediaries are those that provide tax advantages to various types of products such as life insurance and pension related savings and investments.

\section{A Greater Range of Financial Products and Markets}

More financial products allow investors to form diversified portfolios with more than just stocks. As discussed above, corporate bond markets, along with better enforcement of bankruptcy laws and bond rating agencies, provide an alternative class of assets to stocks. Second, the introduction of more derivative securities such as forwards, futures, and options on commodities (already in place and trading) as well as on other securities, enlarges the risk management toolbox of investors and firms. In fact, China has launched an index future on April 16th, 2010, tracking the Shanghai-based Hushen 300, the index of 300 Shanghai- and Shenzhen listed class A-shares. On the

first day four contacts were traded. Of the 2,200 index future accounts opened as of May 4, 2010, 95\% of them were individuals, and the rest were institutional investors. The proportion of institutional investors is expected to rise in the future, since the index future is targeted mainly toward more sophisticated investors for hedging purposes. The launch of this long awaited index future is a major step in the reform of capital markets in China and introduces a new tool for risk management. Along with the index future, margin trading and short selling of shares were also permitted in April.

Third, the expansion of their coverage and products (e.g., in property and auto insurance as well as life and medical insurance) by insurance companies, and the introduction and development of asset-backed securities and other structured finance products by financial services companies can further diversify the supply of financial products. 


\section{The Non-standard Financial Sector and Evidence on Hybrid Sector Firms}

In this section we study how the non-standard financial sector supports firms in the Hybrid Sector to raise funds and to grow from start-ups to successful industry leaders. We also examine the alternative governance mechanisms employed by investors and firms that can substitute for formal corporate governance mechanisms. Due to data limitations, much of this evidence is by necessity anecdotal or by survey. ${ }^{32}$

We first compare the Hybrid Sector with the State and Listed Sectors to highlight the importance of its status in the entire economy in Section V.1. Second, we consider survey evidence in Section V.2. Finally, Section V.3 provides discussions and comparisons of alternative financing channels and governance mechanisms that support the growth of the Hybrid Sector versus formal financing channels (through banks and markets) and governance mechanisms (laws and courts).

\section{V.1 Comparison of Hybrid Sector vs. State and Listed Sectors}

Figure 7-A compares the level and growth of industrial output produced in the State and Listed Sectors combined vs. that of the Hybrid Sector from 1998 to $2009 .^{33}$ The output from the Hybrid Sector has been steadily increasing during this period and exceeded that of the other two sectors in 1998. The total output in 2009 is almost \$5,700 billion for the Hybrid Sector, while it is around \$2,500 billion in the State and Listed Sectors combined. ${ }^{34}$ The Hybrid Sector grew at an annual rate of over 23\% between 1998 and 2009, while the State and Listed Sectors combined grew at around 15\% during the same period. ${ }^{35}$ In addition, the growth rates for investment in fixed assets of these sectors are comparable (China Statistics Yearbooks; and AQQ (2005)), which implies that the Hybrid Sector is more productive than the State and Listed Sectors. In fact, with large samples of firms (from sources) with various ownership structures, Liu (2007) and Dollar and Wei (2007) both

\footnotetext{
${ }^{32}$ All firms including Hybrid Sector firms must disclose accounting and financial information to the local Bureau of Commerce and Industry, and most of the reports are audited. However, these data are then aggregated into the Statistical Yearbook without any firm-level publications.

${ }^{33}$ The National Bureau of Statistics (NBS) of China revised its total industrial output statistics in the 2000 year book without any explicit explanations. The outputs in previous years (i.e. 1997) were significantly revised down compared to the 1998 year book. To be consistent and avoid confusion, we only use data from the NBS after 1998.

${ }^{34}$ Due to data limitations, our calculations underestimate the output of the State and Listed Sectors. We use the output produced by SOEs and listed firms in which the state has at least a 50\% ownership stake as the total output for these sectors, but this calculation excludes output from listed firms that are not majority owned by the state; the output for the Hybrid Sector is the difference between the total output and the total for the other two sectors. However, as mentioned above, only around $20 \%$ of all listed firms do not have the state as the largest owner, hence the total output of these firms is not likely to change our overall conclusion on the dominance of the Hybrid Sector over the other two sectors.

${ }^{35}$ There is an ongoing process of privatizing SOEs. Potentially this may bias the growth rate of the Hybrid Sector higher, as there are firms shifting from the State Sector to the Hybrid Sector. However, the overwhelming majority of SOEs became Listed Sector firms (the main channel through which SOEs were partially privatized prior to 2004), thus this process is unlikely to change the validity of the results above.
} 
find that the returns to capital is much higher in non-state sectors than the State Sector, and that a capital reallocation from state to private sectors will generate more growth in the economy. Fan et al. (2006) and Li et al. (2007) find that state-owned firms in China have a much easier access to the debt market and accordingly higher leverage than non-state firms. One reason for the differences is that due to government protection (for economic and social/political reasons) the costs for bankruptcy and financial distress are much lower for state-owned firms. These firms also have easier access to bank loans, especially credit extended by state-owned banks.

All of the above facts make the growth of the Hybrid Sector even more impressive. Not surprisingly, there has been a fundamental change among the State, Listed, and Hybrid Sectors in terms of their contribution to the entire economy: the State Sector contributed more than two thirds of China’s GDP in 1980 and (non-agricultural) privately owned firms, a type of Hybrid Sector firm, were negligible, but in 2009 the State Sector only contributed 30\% of the GDP (China Statistical Yearbook, 1998-2010). The above trend of the Hybrid Sector replacing the State Sector is likely to continue in the near future.

\section{Insert Figures 7-A and 7-B here.}

Figure 7-B presents the number and growth of non-agricultural employees in the three sectors. The Hybrid Sector is a much more significant source for employment opportunities than the State and Listed Sectors. Over the period from 1990 to 2010, the Hybrid Sector employs an average of over 77\% of all non-agricultural workers; the TVEs (part of the Hybrid Sector) have been the most important employers providing (non-agricultural) jobs for residents in the rural areas, while (non-agricultural) privately owned firms employ more than $40 \%$ of the workforce in the urban areas. Moreover, the number of employees working in the Hybrid Sector has been growing at 1.5\% over this period, while the labor force in the State and Listed Sectors has been shrinking. ${ }^{36}$ These patterns are particularly relevant for China, given its vast population and potential problem of unemployment.

\section{V.2 Survey Evidence}

Much of the information concerning the Hybrid Sector comes from surveys. We focus on evidence in AQQ (2005) and Cull and Xu (2005). The most significant findings of these surveys regarding financing channels are the following. First, during the startup stage, funds from founders' family and friends are an essential source of financing. Banks can also play an important role.

\footnotetext{
${ }^{36}$ Our calculations of the total number of workers employed by the Hybrid Sector actually underestimate the actual work force in the sector, because the Chinese Statistics Yearbooks do not provide employment data for all types of firms (by ownership structure), especially small firms, in the Hybrid Sector.
} 
Second, internal financing, in the form of retained earnings, is also important. During their growth period financing from private credit agencies (PCAs), instead of banks, as well as trade credits are key channels for firms in AQQ’s sample. As documented by Tsai (2002), PCAs take on many forms, from shareholding cooperative enterprises run by professional money brokers, lenders and middlemen, to credit associations operated by a group of entrepreneurs (raising money from group members and from outsiders to fund firms; zijin huzushe), from pawnshops to underground private money houses.

As far as corporate governance is concerned, when asked about what type of losses concern them the most if the firm failed, every firm's founders/executives (100\%) included in the AQQ study said reputation loss is a major concern, while only $60 \%$ of them said economic losses are of major concern. Competition also appears to be an important factor ensuring firms are well run.

Cull and $\mathrm{Xu}$ (2005) find that firms in most regions and cities rely on courts to resolve less than $10 \%$ of business-related disputes (the highest percentage is $20 \%$ ), with a higher reliance on courts in coastal and more developed areas. One reason that firms go to courts to resolve a dispute is because the courts are authoritative so that the dispute will be resolved even though the resolution may not be fair (e.g., Clarke et al. 2008).

\section{V.3 Discussion on How the Non-standard Financial Sector Works}

In this subsection we first discuss mechanisms within the non-standard financial sector in supporting the growth of the Hybrid Sector. We then compare these alternative institutions that operate outside the legal system with the law and legal institutions that have been widely regarded as the basis for conducting finance and commerce. There are two aspects to alternative financing channels in the Hybrid Sector. The first is the way in which investment is financed. The second is corporate governance. We consider each in turn.

Once a firm is established and doing well, internal finance can provide the funds necessary for growth. AQQ (2005) find that about 60 percent of the funds raised by the Hybrid Sector are generated internally. Of course, internal finance is fine once a firm is established but this raises the issue of how firms in the Hybrid Sector acquire their "seed" capital, perhaps the most crucial financing during a firm's life cycle. AQQ present evidence on the importance of alternative and informal channels, including funds from family and friends and loans from private (unofficial) credit agencies (see also Tsai (2002)). There is also evidence that financing through illegal channels, such as smuggling, bribery, insider trading and speculations during early stages of the development of financial markets and real estate market, and other underground or unofficial businesses can also play 
a critical role in the accumulation of seed capital.

Perhaps the most significant corporate governance mechanism is competition in product and input markets, which has worked well in both developed and developing countries (e.g., McMillan 1995, 1997; Allen and Gale 2000b). What we see from the success of Hybrid Sector firms in WenZhou and other surveyed firms recounted in AQQ, suggest that it is only those firms that have the strongest comparative advantage in an industry (of the area) that survived and thrived. A relevant factor for competition in an industry is entry barriers for new firms, as lower entry barriers foster competition. Djankov, La Porta, Lopez-de-Silanes, and Shleifer (DLLS hereafter, 2002) examine entry barriers across 85 countries, and find that countries with heavier (lighter) regulation of entry have higher government corruption (more democratic and limited governments) and larger unofficial economies. With much lower barriers to entry compared to other countries with similar (low) per capita GDP, China is once again an “outlier” in the DLLS sample given that China is one of the least democratic countries, and such countries tend to have high barriers to entry. Survey evidence from AQQ (2005) reveals that there exist non-standard methods to remove entry barriers in China, which can reconcile these seemingly contradictory facts.

Another mechanism is reputation, trust, and relationships. Greif $(1989,1993)$ argues that certain traders' organizations in the $11^{\text {th }}$ century were able to overcome problems of asymmetric information and the lack of legal and contract enforcement mechanisms, because they had developed institutions based on reputation, implicit contractual relations, and coalitions. Certain aspects of the growth of these institutions resemble what worked to promote commerce and the financial system in China prior to 1949 (e.g., Kirby (1995)) and the operation of the non-standard financial sector today (AQQ (2005)), in terms of how firms raise funds and contract with investors and business partners. In addition, Greif (1993) and Stulz and Williamson (2003) point out the importance of cultural and religious beliefs for the development of institutions, legal origins, and investor protections.

The above factors are of particular relevance and importance to China's development of institutions. Without a dominant religion, some argue that the most important force in shaping China's social values and institutions is the set of beliefs first developed and formalized by Kongzi (Confucius). This set of beliefs clearly defines family and social orders, which are very different from western beliefs on how legal codes are formulated. Using the World Values Survey conducted in the early 1990s, LLSV (1997b) find that China has one of the highest levels of social trust among a 
group of 40 developed and developing countries. ${ }^{37}$ We interpret high social trust in China as being influenced by Confucian beliefs. Throughout this chapter and AQQ (2005; 2008) we have presented evidence that reputation and relationships make many financing channels and governance mechanisms work in China’s Hybrid Sector.

There are other effective corporate governance mechanisms. First, Burkart et al. (2003) link the degree of separation of ownership and control to different legal environments, and show that family-run firms will emerge as the dominant form of ownership structure in countries with weak minority shareholder protections, whereas professionally managed firms are the optimal form in countries with strong protection. Survey evidence on the Hybrid Sector in AQQ and empirical results on the Listed Sector, along with evidence in Claessens et al. (2000, 2002) and ACDQQ (2008), suggests that family firms are a norm in China and other Asian countries, and these firms have performed well. Second, Allen and Gale (2000a) show that, if cooperation among different suppliers of inputs is necessary and all suppliers benefit from the firm doing well, then a good equilibrium with no external governance is possible, as internal, mutual monitoring can ensure the optimal outcome. AQQ (2005) and ACDQQ (2008) present evidence on the importance of trade credits as a form of financing for firms in the Hybrid Sector. Cooperation and mutual monitoring can ensure payments (as long as funds are available) among business partners despite the lack of external monitoring and contract enforcement. The importance of trade credits is also found in other emerging economies (e.g., ACDQQ (2012) on India) as well as in developed countries (Burkart et el. (2011) on the U.S.).

It is worth mentioning how entrepreneurs and investors alleviate and overcome problems associated with government corruption. According to proponents of institutional development (e.g., Rajan and Zingales 2003b; Acemoglu and Johnson 2005), poor institutions, weak government and powerful elites can severely hinder China's long-run economic growth. However, our evidence shows that corruption has not prevented a high rate of growth for China's firms, in particular, firms in the Hybrid Sector, where legal protection is perhaps weaker and problems of corruption worse compared to firms in the State and Listed sectors.

A potentially effective solution for corruption is competition among local governments/bureaucrats from different regions within the same country. Entrepreneurs can move from region to region to find the most supportive government officials for their private firms, which in turn motivates officials to lend "helping hands" rather than "grabbing hands" in the provision of

\footnotetext{
${ }^{37}$ Interestingly, the same survey, used in LLSV (1997b), finds that Chinese citizens have a low tendency to participate in civil activities. However, our evidence shows that, with effective alternative mechanisms in place citizens in the developed regions of China have a strong incentive to participate in business/economic activities.
} 
public goods or services (e.g., granting of licenses to start-up firms), or else there will be an outflow of profitable private businesses from the region (Allen and Qian 2009). This remedy is typically available in a large country with diverse regions like China. Complementing this view, Xu (2011) reviews China's unique institutional foundation of “regionally decentralized authoritarian system,” in which the sub-national governments have considerable autonomous power over regional economic decisions and at the same time remain under the control of the central government. Under this structure, local governments play a major role in supporting TVEs, allocating bank credits to firms, choosing good firms to get listed. This system alleviates the information problem that regulators face, and creates incentives for sub-national governors though personnel control and regional competition. $\mathrm{Xu}$ argues that this governance structure is responsible for the spectacular economic growth of China, despite weak enforcement of formal laws.

To summarize, the extraordinary economic performance of China in recent decades, especially that of the Hybrid Sector, raises questions about the conventional wisdom of using the legal system as the basis of commerce. Most observers would characterize the economic performance in China and India as 'successful despite the lack of western-style institutions,' and the failure to adopt western institutions will be one of the main factors to halt the long-run economic growth. By contrast, Allen and Qian (2010) argue that China’s economy has been successful because of this lack of western-style institutions - in that conducting business outside the legal system in fastgrowing economies such as China can actually be superior to using the law as the basis for finance and commerce.

Focusing on dispute resolution and contract enforcement mechanisms based on the law and courts vs. alternative mechanisms operating outside the legal system, Allen and Qian (2010) argue that despite many well-known advantages, there are disadvantages in using legal institutions. First, recent research on political economy factors, and in particular, work by Rajan and Zingales (2003a,b) shows that rent-seeking behaviors by vested interest groups can turn legal institutions into barriers to changes. We expect these problems to be much more severe in developing countries and the costs of building good institutions can be enormous. ${ }^{38}$ One way to solve this problem is not to use the law as the basis for commerce but instead to use alternative mechanisms outside the legal system. Evidence

\footnotetext{
${ }^{38}$ A frequently talked about and controversial topic is intellectual property rights including patents and copyrights. The practice of enforcing intellectual property rights by courts is much more vigilant and prevalent in developed countries than in developing countries such as China. An extensive literature in economics has found mixed evidence on the relationship between patent/copyright protection and the pace of innovations. While exclusive property rights provide strong incentives for innovations and do lead to more innovations in a few industries such as chemicals and pharmaceuticals, excessive protection deters competition, which is another important factor in spurring innovations.
} 
presented in this chapter and other related work on China and other emerging economies (e.g., ACDQQ (2012) on India) suggests that these alternative mechanisms can be quite effective.

Second, in democracies there can be a lengthy political process before significant changes can be approved (by the majority of the population and/or legislature), and the people in charge of revising the law (e.g., politicians and judges) may lack the expertise of business transactions and have limited capacity (time and effort) to examine the proposed changes. ${ }^{39}$ In the context of a fastgrowing economy with frequent changes such as China, Allen and Qian (2010) show that there is an additional advantage of using alternative institutions because this type of system can adapt and change much more quickly than when the law is used. In particular, competition can ensure the most efficient mechanism prevails and this process does not require persuading the legislature and the electorate to revise the law when circumstances change.

To conclude, we argue that while legal institutions along with formal financing channels are an integral part of developed economies’ institutions, alternative mechanisms and financing channels play a much more prominent role in emerging economies, and can be superior to legal mechanisms in supporting business transactions in certain industries or entire economies. Therefore, the development of alternative dispute resolution and contract enforcement mechanisms alongside the development of legal and other formal institutions can promote a broader base of economic growth that is also more sustainable in emerging economies. The coexistence of and competition between alternative and legal mechanisms can also exert positive impact on the development of legal institutions, so that they are less likely to be captured by interest groups and become more efficient in adapting to changes.

\section{Financial Crises}

Financial crises often accompany the development of a financial system. Conventional wisdom says that financial crises are bad. Often they are very bad, as they disrupt production and lower social welfare as in the Great Depression in the U.S. Hoggarth et al. (2002) carefully measure the costs of a wide range of recent financial crises and find that these costs are on average roughly 15-20 percent of GDP. It is these large costs that make policymakers so averse to financial crises.

\footnotetext{
${ }^{39}$ A good example is the U.S. payment system. At the beginning of the $21^{\text {st }}$ Century the U.S. had a $19^{\text {th }}$ Century system: Checks had to be physically transported from where they were deposited to a central operations center, then to the clearer and then back to the banks they were drawn on. Despite repeated calls for changes from the banks and businesses, the U.S Congress did not act on this simple yet costly problem, until after September 11, 2001. After the terrorist attack all commercial flights were grounded for several days, completely halting the check clearing process. The Check Clearing for the $21^{\text {st }}$ Century Act was signed in October 2003, allowing electronic images to be a substitute for the original checks, and thus the clearing process is no longer dependent on the mail and transportation system.
} 
It is worthwhile to point out, however, that financial crises may be welfare improving for an economy. One possible example is the late nineteenth century U.S., which experienced many crises but at the same time had a high long run growth rate. In fact, Ranciere et al. (2003) report an empirical observation that countries which have experienced occasional crises have grown on average faster than countries without crises. They develop an endogenous growth model and show theoretically that an economy may be able to attain higher growth when firms are encouraged by a limited bailout policy to take more credit risk in the form of currency mismatch, even though the country may experience occasional crises (see Allen and Oura (2004) for a review of the growth and crises literature, Allen and Gale (2004a) who show that crises can be optimal and Allen and Gale (2007) for a review of the crises literature).

In this section, we consider financial crises in China. Given China's current situation with limited currency mismatches any crisis that occurs is likely to be a classic banking, currency or twin crisis. It is perhaps more likely to be of the damaging type that disrupts the economy and social stability than of the more benign type that aids growth. The desirability of preventing crises thus needs to be taken into account when considering reforms of China's financial system. First, we examine how China can prevent traditional financial crises, including a banking sector crisis and a stock market or real estate crisis/crash. We then discuss the impact of different types of financial crises, such as the "twin crises” (simultaneous foreign exchange and banking/stock market crises) that occurred in many Asian economies in the late 1990s, on China.

\section{VI.1 Banking Crises and Market Crashes}

Among traditional financial crises, banking panics, arising from the banks’ lack of liquid assets to meet total withdrawal demands (anticipated and unanticipated), were often particularly disruptive. Over time one of the most critical roles of central banks came to be the elimination of banking panics and the maintenance of financial stability. To a large degree central banks in different countries performed well in this regard in the period following the Second World War. However, in recent years, banking crises are often preceded by abnormal price rises (“bubbles”) in the real estate and/or stock markets. At some point the bubble bursts and assets markets collapse. In many cases banks and other intermediaries are overexposed to the equity and real estate markets, and following the collapse of asset markets a banking crisis ensues. Allen and Gale (2000c) provide a theory of bubbles and crises based on the existence of an agency problem. Many investors in real estate and stock markets obtain their investment funds from external sources. If the providers of the funds are unable to observe the characteristics of the investment, and because of the investors' limited liability, 
there is a classic risk-shifting problem (Jensen and Meckling 1976). Risk shifting increases the return to risky assets and causes investors to bid up asset prices above their fundamental values. A crucial determinant for asset prices is the amount of credit that is provided for speculative investment. Financial liberalization, by expanding the volume of credit, can interact with the agency problem and lead to a bubble in asset prices.

As discussed above in Section III, if NPLs continue to accumulate and/or if growth slows significantly then there may be a banking crisis in China. This may involve withdrawal of funds from banks. However, given the government's strong position regarding the low level of debt (Table 3-A), it is feasible for the government to prevent this situation from getting out of control. Since the real estate markets in Shanghai and Shenzhen (largest volume and most developed) and other major cities have already experienced bubbles and crashes (see China Industry Report, http://www.cei.gov.cn, http://house.focus.cn and Cao (2008) for more details), it is quite possible that similar episodes in the future could cause a banking crisis that will be more damaging to the real economy. With booming real estate markets, there will be more speculative money poured into properties with a large amount coming from banks. The agency problem in real estate lending and investment mentioned above worsens this problem. If the real estate market falls significantly within a short period of time, defaults on bank loans could be large enough to trigger a banking panic and crisis. The size of the stock market during the first decade of its existence was small relative to the banking sector and the overall economy, and hence a crash in the market could hardly put a dent in the real economy. However, given the quick growth of the stock market (as shown in Table 5-A) and the fact large and small investors may borrow (from banks) to finance their investment, especially during a bubble period, a future market crash could have much more serious consequences. Overall, a banking crisis triggered by crashes in the real estate and/or stock markets represents the most serious risk of a financial crisis in China.

Having said that, we also want to point out that the Chinese government has maintained strong control over the big banks through their (nontradable) shareholdings. While government control may have a negative effect in more developed countries in terms of efficiency, it may be beneficial in countries with less developed financial markets. In particular, the government can help to control the risk taking behaviors of the banks by regulations and direct interventions as a shareholder. Moreover, in the case of a crisis, the government has the ability to speed up the recovery and maintain the stability of the market by loan expansion if it has control over major banks. In fact, the Chinese banking sector and financial markets were not affected much by the 2007-2009 
global financial crisis. Though we recognized earlier in the paper that government's dual roles as regulator and as majority owner can be problematic, this can also be beneficial both in terms of preventing and coping with a crisis.

\section{VI.2 Capital Account Liberalization, Sterilization, Twin Crises and Contagion}

After the collapse of the Bretton Woods system in the early 1970s, a different breed of financial crisis emerged. Lindgren, Garcia, and Saal (1996) found that three quarters of the IMF's member countries suffered some form of banking crisis between 1980 and 1996, and their study did not include the subsequent Asian financial crisis in 1997. In many of these crises, banking panics in the traditional sense were avoided either by central bank intervention or by explicit or implicit government guarantees. But as Kaminsky and Reinhart (1999) find, the advent of financial liberalization in many economies in the 1980s, in which free capital in- and out-flows and the entrance and competition from foreign investors and financial institutions follow in the home country, has often led to "twin” banking and currency crises. A common precursor to these crises was financial liberalization and significant credit expansion and subsequent stock market crashes and banking crises. In emerging markets this is often then accompanied by an exchange rate crisis as governments choose between lowering interest rates to ease the banking crises or raising them to defend the home currency. Finally, a significant fall in output occurs and the economies enter recessions.

\section{Liberalization of the Capital Account and Financial Sector}

Capital account liberation can attract more foreign capital, but large scale and sudden capital flows and foreign speculation significantly increase the likelihood of a twin crisis. The first key question is, when and to what extent a country opens its capital account and financial sector to foreign capital and foreign financial institutions? With a model of endogenous financial intermediation, Alessandria and Qian (2005) demonstrate that an efficient financial sector prior to liberalization is neither necessary nor sufficient for a successful financial liberalization. Applying these ideas to China, even though the overall efficiency of China's banking sector (especially stateowned banks) is still low compared to international standards, banks can have a stronger incentive to limit the moral hazard concerning borrowers’ choices of investment projects through monitoring and designing of loan contracts (e.g., adjusting interest rates and/or maturities) following a capital account liberalization. Therefore, the efficiency of the banking sector improves and the liberalization can generate a large welfare increase, since it leads to both a larger scale of investment and a better 
composition of investment projects. This is more likely to occur with low interest rates in international markets (so that cost of capital for domestic banks is also low). A financial sector liberalization, which allows foreign financial institutions to enter China’s lending markets, can further improve welfare as more competition provides stronger incentives for all banks to further discourage moral hazard in investment.

\section{Sterilization of Foreign Currency Reserves}

China has experienced a large increase in its foreign exchange reserves since 2001, due to a continuous inflow of capital and the commitment to maintain a fixed rate against the US dollar initially and then a crawling peg exchange rate regime after 2005. Figure 8-A plots the exchange rate of RMB against US dollar. The RMB kept appreciating against US dollar until mid 2008, when the exchange rate stayed flat again at around 6.83 RMB/US\$. It resumed the path of appreciation in June 2010 and the exchange rate further dropped to 6.5 RMB/US by April 2011. Figure 8-B plots monthly foreign reserves as shown on the balance sheet of the PBOC; a clear trend emerges as the reserves increased rapidly since 2003. ${ }^{40}$ On the balance of payments side, the current account surplus grew from \$37 billion in 1997 to \$305.4 billion in 2010; net export grew from 2.5\% of GDP in 2004 to 8\% of GDP in 2008 and then dropped to 3.1\% in 2010 due to a decrease in net exports. The capital account was mostly positive during the period 1995 to 2009, implying a net capital inflow. The current account surplus has come mainly from trade surpluses, while the capital account surplus mainly comes from FDI. It has long been recognized that a large stock of foreign reserves has both pros and cons. Abundant foreign reserves enable a country to maintain a stable exchange rate and to meet its foreign debt obligations. It can also be used to cushion the sudden shocks on a country's current and capital accounts. However, an increase in foreign exchange reserves leads to an accumulation of foreign assets, a component of the monetary base. Thus an increase in foreign reserves, ceteris paribus, causes monetary expansion and puts inflationary pressures on the economy, resulting in an appreciation of the real exchange rate. This experience is not unique for China. Many East Asian countries have experienced similar problems induced by large (private) capital inflows starting in the late 1980s.

\section{Insert Figures 8-A and 8-B here.}

To offset the expansionary effect of the increasing foreign reserves, the central bank can sterilize the foreign assets by taking opposite actions with domestic assets, or implement other

\footnotetext{
${ }^{40}$ The PBOC has made use of its foreign reserves in ways other than investing in low risk assets such as long term government bonds. As discussed above, some foreign reserves were used to recapitalize the large state owned financial institutions.
} 
contractionary monetary policies. In China’s case, the major sterilization tools are open market operations (OMO) and raising required reserve ratios. These two methods affect the liability side of the central bank's balance sheet in a similar way. Generally the cost of sterilization using required reserves is lower than open market operations, since the central bank pays minimal interest on required and excess reserves. OMOs in China mainly include central bank bill issuance and short term repurchases operations (repos, usually within 91 days). Since February 2003, the central bank has engaged in two or more OMOs each week. The total PBOC bonds outstanding as percentage of foreign reserves has been increasing consistently from 2000 to 2010, implying an increasing trend in sterilization. $^{41}$

Moreover, China has been gradually raising the required reserve ratios since the third quarter of 2003, corresponding to an increase in foreign reserves inflows. The required reserve ratio rose from $6 \%$ to $21.5 \%$ in June 2011, an historical high. Since Chinese commercial banks tend to maintain a high excess reserve ratio due to a lack of alternative investment channels, the PBOC has decreased the interest rate on excess reserves from $1.62 \%$ in 2003 to $0.72 \%$ in 2008 to discourage the hoarding of excess reserves. To make sterilization effective, China also has to impose tight capital controls. As the famous "trilemma" implicates, with a fixed exchange rate and free capital flows, the sterilization process will be immediately offset by further capital inflows. Though it has been documented that capital controls in China are somewhat porous (Prasad and Wei (2007)), it is still widely believed that China has successfully sterilized at least some of its rising foreign reserves (e.g., Prasad and Goodfriend (2006), Ouyang, Rajan and Willett (2007), He. at el. (2005)). Moreover, due to a combination of rapid increases in foreign reserves and low interest rates on domestic bonds, the PBOC's income from foreign reserve investment is likely to exceed the sterilization cost stemming from central bank bill issuance and high required reserve ratios, enabling China to carry out sterilization to a large extent. Nevertheless, possible appreciation of the RMB may have a profound negative impact on the PBOC’s income from foreign reserves in domestic currency terms.

\section{Currency Crisis and Banking Crisis (A Twin Crisis)}

A currency crisis that may trigger a banking crisis is a possibility. The rapid increase in foreign exchange reserves in recent years suggests there is a lot of speculative money in China in anticipation of an RMB revaluation. If there is a significant future revaluation or if after some time it becomes clear there will not be one then much of this money may be withdrawn. What happens then

\footnotetext{
${ }^{41}$ There are also non-market tools such as transferring the deposits from the commercial banking system to the central bank. In recent years, the PBOC also started making foreign exchange swaps with big commercial banks as a tool for controlling liquidity.
} 
will depend on how the government and central bank respond. If they allow the currency to float so they do not use up the exchange reserves then any falls in the value of the RMB may occur quickly and this may limit further outflows. If they try to limit the exchange rate movement then there may be a classic currency crisis. This is in turn may trigger a banking crisis if there are large withdrawals from banks as a result. Quickly adopting a full float can help to avoid a twin crisis, and thus reduce the overall economic costs of the currency crisis. ${ }^{42}$

\section{Financial Contagion}

Another phenomenon that has been present in many recent crises (e.g., the 1997 Asian crisis) is that financial crises are contagious. A small shock that initially affects only a particular region or sector can spread by contagion within the banking system or asset markets to the rest of the financial sector, then to the entire economy and possibly other economies. Contagion can occur in a number of ways. In the Chinese context with tight capital control and where financial markets are relatively unimportant it is most likely they will occur either from contractually interconnected financial institutions or large asset price movements that cause spillovers to financial institutions.

Allen and Gale (2000d) focus on the channel of contagion that arises from the overlapping claims that different regions or sectors of the banking system have on one another through interbank markets. When one region suffers a banking crisis, the other regions suffer a loss because their claims on the troubled region fall in value. If this spillover effect is strong enough, it can cause a crisis in the adjacent regions, and a contagion can occur which brings down the entire financial system. Allen and Gale (2004b) show how large price falls can come about as a result of forced liquidations when there is a limited supply of liquidity in the market. Cifuentes et al. (2005) show that contagion is likely to be particularly severe when these two factors interact.

\section{Insert Table 7 here.}

Given China’s current financial system, what is the likelihood of financial contagion caused by contractual interlinkages as in the interbank market or because of a meltdown in asset prices if there are forced sales? China’s interbank market grew very quickly since its inception in 1981; in fact, the growth of this market was so fast, with the participation of many unregulated financial institutions and with large amount of flows of funds through this market to fixed asset investment, that it exacerbated high inflation in the late 1980s. Since then the government and PBOC increased

\footnotetext{
${ }^{42}$ Chang and Velasco (2001) develop a model of twin crises based on the Diamond and Dybvig (1983) model of bank runs. Money enters agents' utility function, and the central bank controls the ratio of currency to consumption. In some regimes, there exists both a "good" equilibrium in which early (late) consumers receive the proceeds from short-term (long-term) assets, and a "bad" equilibrium in which everybody believes a crisis will occur and these beliefs are selffulfilling. If the bad equilibrium occurs, there is a twin crisis.
} 
their regulation by limiting participation of non-bank financial institutions and by imposing restrictions on interest rate movements. In 1996 a nation-wide, uniform system of interbank markets was set up. It contains two connected levels: the primary network, which includes the largest PBOC branches, large commercial banks, and a few large non-bank financial institutions, and the secondary network that includes many banks and non-bank institutions and their local branches (see China Interbank Market Annual Reports for more details). Table 7 documents the growth of the interbank market during 2001-2010: while the trading volume of long maturity contracts (20 days or longer) is low, the volume of short-term contracts (overnight and week-long) has been high (reaching RMB 10 trillion to 20 trillion, or $\$ 1.5$ billion to $\$ 2.9$ billion). Therefore, the increasing interlinkages can potentially create a contagion if a crisis develops in one area or sector.

With regard to a meltdown of asset prices, this can happen because of a limited supply of liquidity if there is a rapid liquidation of assets. It seems unlikely that this can occur and cause a serious problem in China’s securities markets. A more serious threat is real estate markets if there are bankruptcies and forced selling. This could potentially interact with bank interlinkages and cause a systemic problem. As mentioned above, a crash in real estate and/or stock markets could quite possibly be the cause of a financial crisis in China.

\section{Summary and Concluding Remarks}

One of the most frequently asked questions about China's financial system is whether it will stimulate or hamper its economic growth. Our answer to this question, based on examining the history and current status of the financial system and comparing them to those of other countries, is in four parts. First, the large banking sector dominated by state-owned banks has played a much more important role in funding the growth of many types of firms than financial markets. While the problem of NPLs has been under control in recent years, continuing the improvement of the efficiency of major banks toward international standards will allow growth to continue. Second, the stock market has been growing fast since 1990, but has played a relatively limited role in supporting the growth of the economy. However, with rapid growth that is likely to be sustained in the near future the role of the financial markets in the economy will become increasingly more significant.

If we can summarize that the role of the banking sector and financial markets has been that they have done enough not to slow down the growth of the economy, our third conclusion is that alternative financing channels have had great success in supporting the growth of the Hybrid Sector, which contributes most of the economic growth compared to the State and Listed Sectors. The non- 
standard financial sector relies on alternative financing channels including internal finance, and on alternative governance mechanisms, such as those based on trust, reputation and relationships, and competition in output and input markets to support the growth of the Hybrid Sector. It is possible that these alternative institutions are superior to western-style legal institutions in supporting a fastgrowing economy such as China’s.

We conclude by pointing out that economic stability is crucial for the continuing development of the Chinese economy, and the stability of the financial system relates to economic stability in three dimensions. The continuing effort by banks to reduce NPLs and improve efficiency can help to avoid a banking crisis, while the efforts to improve the regulatory environment surrounding the financial markets (including governance and accounting standards) can help to prevent a crash/crisis in the stock and/or real estate markets. If China further opens the capital account, there will be a large inflow of foreign capital, but large scale capital flows and speculations also bring the risk of a twin crisis (foreign exchange and banking/stock market crisis), which severely damaged emerging economies in Asia in 1997. 


\section{References}

1. Acemoglu, Daron and Johnson, Simon, 2005. “Unbundling Institutions,” Journal of Political Economy 113, 949-995.

2. Alessandria, George, and Jun Qian, 2005. "Endogenous Financial Intermediation and Real Effects of Capital Account Liberalization,” Journal of International Economics 67, 97-128.

3. __ a a a Douglas Gale, 1999. "Diversity of Opinion and Financing of New Technologies,” Journal of Financial Intermediation 8, 68-89.

4. __ a a _ _ 2000a. Comparing Financial Systems, MIT Press, Cambridge, MA.

5. ___ and __ 2000b. "Corporate Governance and Competition,” in Corporate Governance: Theoretical and Empirical Perspectives, Xavier Vives, ed., Cambridge University Press, London, 23-94.

6. ___ a a _ _ 2000c. “Bubbles and Crises,” Economic Journal 110, 236-255.

7. ___ a _ and _ _ 2000d. "Financial Contagion,” Journal of Political Economy 108, 1-33.

8. _ $\_$, and _ _ 2004a, "Financial Intermediaries and Markets" (with D. Gale) Econometrica 72, 10231061.

9. __ _ and _ _ 2004b, "Financial Fragility, Liquidity and Asset Prices” (with D. Gale), Journal of the European Economic Association 2, 1015-1048.

10. ___ and __ 2007, Understanding Financial Crises, Clarendon Lectures in Finance, Oxford University Press, Oxford and New York.

11. ___ and Hiroko Oura, 2004. "Sustained Economic Growth and the Financial System,” Monetary and Economic Studies, Bank of Japan, 22 S-1, 95-119.

12. ___ and Jun Qian, 2009. “Corruption and Competition,” working paper, University of Pennsylvania.

13. ___ and __ 2010. "Comparing Legal and Alternative Institutions in Commerce,” Global Perspectives on the Rule of Law, Heckman et al., Eds., Routledge-Cavendish.

14. ___ _ _ and Meijun Qian, 2005. “Law, Finance, and Economic Growth in China,” Journal of Financial Economics 77, 57-116.

15. ___ _ _ and __ 2008. “China's Financial System: Past, Present, and Future,” Chapter 14 in China's Great Economic Transformation, L. Brandt and T. Rawski, Eds., Cambridge University Press.

16.

_ _ Chenyu Shan, and Mengxin Zhao, 2012. “The IPO of Industrial and Commercial Bank of China and the 'Chinese Model' of Privatizing Large Financial Institutions

,’European Journal of Finance, forthcoming.

17. __ Rajesh Chakrabarti, Sankar De, Jun Qian, and Meijun Qian, 2008. “The Financial System Capacities of China and India,” working paper, Wharton School, University of Pennsylvania. 
18. and , 2012. “Financing Firms in India,” Journal of Financial Intermeditation, 21, 409-445.

19. Berger, Allen, Iftekhar Hasan, and Mingming Zhou, 2009. "Bank Ownership and Efficiency in China: What will Happen in the World’s Largest Nation?” Journal of Banking and Finance, 33, 113-130.

20. Black, Bernard S. and Ronald J. Gilson, 1998. "Venture Capital and the Structure of Capital Markets: Bank versus Stock Markets,” Journal of Financial Economics 47, 243-277.

21. Brandt, Loren, and Xiaodong Zhu, 2000. "Redistribution in a Decentralized Economy: Growth and Inflation in China under Reform,” Journal of Political Economy 108, 422-439.

22. Bortolotti, Bernardo and Andrea Beltratti, 2006. "The Nontradable Share Reform in the Chinese Stock Market," Working Papers 2006.131, Fondazione Eni Enrico Mattei.

23. Burkart, Mike, Tore Elligensen, and Mariassunta Giannetti. 2011. "What You Sell is What you Lend? Explaining Trade Credits Contracts.” Review of Financial Studies 24, 1261-1298

24. __ Fausto Panunzi, and Andrei Shleifer, 2003. “Family Firms,” Journal of Finance 58, 2167-2201.

25. Cao, Yingxue and Li Liao, 2008. “An International Comparison of Real Estate Prices” (in Chinese), Price theory and practice (Jia Ge Li Lun Yu Shi Jian), v2,2008, p56-57.

26. Chan, Kalok, Albert Menkveld, and Zhishu Yang, 2008. "Information Asymmetry and Asset Prices: Evidence from the China Foreign Share Discount,” Journal of Finance, 63, 159-196.

27. Chang, Roberto, and Andres Velasco, 2001. “A Model of Financial Crises in Emerging Markets,” Quarterly Journal of Economics 116, 489-518.

28. Chu, Yongqiang, and Tien Foo Sing, 2004. "Inflation Hedging Characteristics of the Chinese Real Estate Market,” Journal of Real Estate Portfolio Management 10, 145-154.

29. Chung, Stephanie Po-yin, 2005 "Changes and continuities. Evolution of a Chinese family business (18762004)”, Asia Europe Journal, Volume 3, Number 2

30. Cifuentes, Rodrigo, Gianluigi Ferrucci, and Hyun Song Shin, 2005, "Liquidity Risk and Contagion,” Journal of the European Economic Association 3, 556-566.

31. Claessens, Stijn, Simeon Djankov, and Larry Lang, 2000. "The Separation of Ownership and Control in East Asian Corporations,” Journal of Financial Economics 58, 81-112.

32. ___ _ _ J Joseph Fan, and, and Larry Lang, 2002. "Expropriation of Minority Shareholders in East Asia,” Journal of Finance 57, 2741-2771.

33. Clarke, Donald, Peter Murrell, and Susan Whiting, 2008. "Law, Property Rights and Institutions,” Ch. 11 China's Great Economic Transformation, L. Brandt and T. Rawski, Eds., Cambridge University Press.

34. Cull, Robert, and Colin Xu, 2005. "Institutions, Ownership, and Finance: The Determinants of Reinvestments of Profit among Chinese Firms,” Journal of Financial Economics 77, 117-146.

35. Demirgüç-Kunt, Asli, and Ross Levine, 2001. Financial Structure and Economic Growth: Cross-country Comparisons of Banks, Markets, and Development, MIT Press, Cambridge, Massachusetts. 
36. Diamond, Douglas, and Philip Dybvig, 1983. “Bank Runs, Deposit Insurance, and Liquidity,” Journal of Political Economy 91, 401-419.

37. Djankov, S., La Porta, R., Lopez-de-Silanes, F., Shleifer, A., 2002. “The Regulation of Entry,” Quarterly Journal of Economics 117, 1-37.

38. Dollar, David and Shang-jin Wei, 2007. “Das (Wasted) Kapital: Firm Ownership and Investment Efficiency in China,” working paper, IMF.

39. Du, Julan, Oliver Rui and Sonia Wong, 2008. "Financing Motivated Takeovers: The Case of China,” working paper, Chinese University of Hong Kong.

40. Fan, Joseph, Huang Jun and Zhu Ning, (2008), “Financial Distress without Bankruptcy: The Case of China”, available at http://ihome.cuhk.edu.hk/ b109671/wp/Distress-090408.pdf.

41. Fan, Joseph, Oliver Rui, and Mengxin Zhao, 2006. "Rent Seeking and Corporate Finance: Evidence from Corruption,” working paper, Chinese University of Hong Kong.

42. __ _ T.J. Wong, and Tianyu Zhang 2007. "Politically-connected CEOs, Corporate Governance and PostIPO Performance of China’s Partially Privatized Firms,” Journal of Financial Economics 84, 330-357.

43. Feldstein, Martin, 1999. “Social Security Pension Reform in China,” China Economic Review 10, 99-107.

44. __ 2003. "Banking, Budgets, and Pensions: Some Priorities for Chinese Policy,” speech at the China Development Forum 2003 hosted by the Development Research Center of the State Council of the People’s Republic of China, available at http://www.nber.org/feldstein/chinaforum5.pdf

45. Feldstein, Martin and Jeffrey Liebman, 2006. "Realizing the Potential of China's Social Security Pension System.”, pp. 309-313, chapter 15, in Public finance in China: reform and growth for a harmonious society, Edited by Jiwei Lou, Shuilin Wang, World Bank

46. Franks, Julian, Colin Mayer, and Stefano Rossi, 2003. “Ownership: Evolution and Regulation,” working paper, London Business School.

47. Fung, Peter, Michael Firth, and Oliver Rui, 2003. "Corporate Governance and CEO Compensation in China,” working paper, Chinese University of Hong Kong.

48. Garnaut, Ross, Song Ligang and Yao Yang, 2004, "SOE Restructuring in China”, Stanford Center for International Development Working Paper No. 204

49. Goetzmann William, Köll Elisabeth, 2005, “The History of Corporate Ownership in China: State Patronage, Company Legislation, and the Issue of Control”, NBER volume: A History of Corporate Governance around the World: Family Business Groups to Professional Managers.

50. Goodfriend Marvin. and Prasad Eswar 2006, “A framework for independent monetary policy in China”, Economic Studies, 2007, vol. 53, issue 1, pages 2-41

51. Greif, Avner, 1989. "Reputation and Coalitions in Medieval Trade: Evidence on the Maghribi Traders," Journal of Economic History 49, 857-882.

52. __ 1993. "Contract Enforceability and Economic Institutions in Early Trade: The Maghribi Traders' Coalition,” American Economic Review 83, 525-548. 
53. Guo, Feng and Ying Sophie Huang, 2010. “Does 'Hot Money' Drive China’s Real Estate and Stock Markets?” International Review of Economics \& Finance 19, 452-466.

54. He.D., Chu C., Shu C.and Wong A. (2005), "Monetary management in Mainland China in the face of large capital inflows.” Reserach Memorandum No 07/2005, Hong Kong Monetary Authority

55. Herring, Richard, and N. Chatusripitak, 2000. "The Case of the Missing Market: The Bond Market and Why it Matters for Financial Development,” working paper, Wharton Financial Institutions Center.

56. Hoggarth, Glenn, Ricardo Reis, and Victoria Saporta (2002), "Costs of Banking System Instability: Some Empirical Evidence,” Journal of Banking and Finance 26, 825-855.

57. Hwang, Chuan-Yang, Shaojun Zhang, and Yanjian Zhu, 2006. "Float Liquidity, Speculation, and Stock Prices: Evidence from the Share Structure Reform in China,” Nanyang Technological University Working Paper

58. Jeng, Leslie A., and Philippe C. Wells, 2000. "The Determinants of Venture Capital Funding: Evidence across Countries,” Journal of Corporate Finance 6, 241-289.

59. Jensen, Michael, and William Meckling, 1976. "Theory of the Firm: Managerial Behavior, Agency Costs, and Ownership Structure,” Journal of Financial Economics 3, 305-360.

60. Kaminsky, Graciela, and Carmen Reinhart, 1999. "The Twin Crises: The Causes of Banking and Balanceof-payments Problems,” American Economic Review 89, 473-500.

61. Kane, Edward, 1989. The S\&L Mess: How Did It Happen? Washington, D.C.: The Urban Institute Press.

62. $\_$2003. "What Economic Principles Should Policymakers in Other Countries Have Learned from the S\&L Mess?” Business Economics 38, 21-30.

63. Kato, Takao, and Cheryl Long, 2004. "Executive Compensation and Corporate Governance in China," William Davidson Institute Working Paper No. 690.

64. Kirby, William, 1995. "China Unincorporated: Company Law and Business Enterprise in TwentiethCentury China,” Journal of Asian Studies 54, 43-63.

65. Kortum, Samuel, and Josh Lerner, 2000. “Assessing the Contribution of Venture Capital on Innovation,” RAND Journal of Economics 31, 674-692.

66. ___ _ _ and _ _ 2006. “What Works in Securities Laws?” Journal of Finance 61, 1-32.

67. $\ldots \ldots \ldots$ _ _ and _ _ 1997b. “Trust in Large Organizations,” American Economic Review 87, 333338.

68. Lardy, Nicholas R., 1998. China’s Unfinished Economic Revolution, Brookings Institution Press, Washington, D.C.

69. Lee, Tahirih V., 1993. “Risky Business: Courts, Culture, and the Marketplace,” University of Miami Law Review 47, 1335-1414.

70. Levine, Ross, 2002. “Bank-based or Market-based Financial Systems: Which is Better?” Journal of Financial Intermediation 11, 1-30. 
71. Li, Kai, Heng Yue and Longkai Zhao, 2007. “Ownership, Institutions, and Capital Structure: Evidence from Non-listed Chinese Firms,” working paper, University of British Columbia.

72. Liao, Li, and Bibo Liu, 2008. "Moral Hazard, Information Disclosure and Market Efficiency: Evidence from China’s Share Reform,” working paper, Tsinghua University.

73. Lindgren, C., G. Garcia, and M. Saal, 1996. Bank Soundness and Macroeconomic Policy, Washington, D.C.: International Monetary Fund.

74. Liu, Qiao, 2007. “Institutions, Financial Development, and Corporate Investment: Evidence from an Implied Return on Capital in China,” working paper, University of Hong Kong.

75. McMillan, John, 1995. “China’s Nonconformist Reform,” Economic Transition in Eastern Europe and Russia: Realities of Reform, ed. Edward Lazear, Stanford: Hoover Institution Press, 419-433.

76. __ 1997. "Markets in Transition,” Ch.6 of Advances in Economics and Econometrics Vol. 2, David M. Kreps, and Kenneth F. Wallis, eds., Cambridge: Cambridge University Press, 210-239.

77. ___ and Barry Naughton, 1992. "How to Reform a Planned Economy: Lessons from China,” Oxford Review of Economic Policy 8, 130-143.

78. Mei, Jianping, Jose Scheinkman, and Wei Xiong, 2003. "Speculative Trading and Stock Prices: An Analysis of Chinese A-B Share Premia,” working paper, Princeton University.

79. Michie, R., 1987. The London and New York Stock Exchanges 1850-1914, London: Allen \& Unwin.

80. Morck, R., B. Yeung, and W. Yu, 2000. “The Information Content of Stock Markets: Why do Emerging Markets Have Synchronous Stock Price Movement?” Journal of Financial Economics 58, 215-260.

81. Morrison, Wayne, and Marc Labonte, 2008. "CRS report for congress: China's holding of U.S. securities: Implications for the U.S. Economy”, Congressional research service.

82. Ouyang, Y.A., Rajan R.S. and Willett T.D., 2007, “China as a Reserve Sink: The Evidence from Offset and Sterilization Coefficients”, Hong Kong Institute for Monetary Research

83. Park, Albert, Loren Brandt, and John Giles, 2003. "Competition under Credit Rationing: Theory and Evidence from Rural China,” Journal of Development Economics 71, 463-495.

84. Park, Albert, Sehrt Kaja, 2001. “Tests of Financial Intermediation and Banking Reform in China,” Journal of Comparative Economics 29, 608-644.

85. Perkins, Dwight, and Thomas Rawski, 2008. "Forecasting China’s Economic Growth to 2025,” Ch. 20 in China's Great Economic Transformation, L. Brandt and T. Rawski, Eds., Cambridge University Press.

86. Pistor, Katharina, 2010. “The governance of China’s finance,” forthcoming in NBER book Capitalizing China.

87. Prasad, Eswar and Shang-Jin Wei, 2007. "The Chinese Approach to Capital Flows: Patterns and Possible Explanations," forthcoming in Capital Controls and Capital Flows in Emerging Economies, ed. Sebastian Edwards, Chicago: University of Chicago Press. 
88. Qian, Jun, and Philip Strahan, 2007. "How Laws and Institutions Shape Financial Contracts: The Case of Bank Loans,” Journal of Finance 62, 2803-2834.

89. ___ _ _ and Zhishu Yang, 2011. "The Impact of Incentives and Communication Costs on Information Production: Evidence from Bank Lending,” working paper, Boston College.

90. Qiu, Yuemin, Bing Li, and Youcai Cai, 2000. "Losses of State-Owned Commercial Banks: Reasons and Policy Response," Jingji gongzuozhe xuexi ziliao [Study Materials for Economic Workers], no. 44.

91. Rajan, Raghuram, and Luigi Zingales, 2003a. "The Great Reversals: The Politics of Financial Development in the Twentieth Century,” Journal of Financial Economics 69, 5-50.

92. __ and __ 2003b. Saving Capitalism from Capitalists: Unleashing the Power of Financial Markets to Create Wealth and Spread Opportunity, Random House, New York.

93. Ranciere, Romain, Aaron Tornell, and Frank Westermann, (2003). "Crises and Growth: A Re-evaluation," NBER Working Paper 10073.

94. Stein, Jeremy, 2002. "Information Production and Capital Allocation: Decentralized vs. Hierarchical Firms,” Journal of Finance 57, 1891-1921.

95. Stulz, Rene, and Rohan Williamson, 2003. “Culture, Openness, and Finance,” Journal of Financial Economics 70, 261-300.

96. Tsai, Kellee, 2002. Back-alley Banking, Ithaca, NY: Cornell University Press.

97. Xu, Chenggang, 2011. “The Fundamental Institutions of China’s Reforms and Development,” Journal of Economic Literature 49, 1076-1151.

98. World Bank (2001). "Bankruptcy of State Enterprises in China — A Case and Agenda for Reforming the Insolvency System”.

99. Wu, Jing, Joseph Gyourko, and Yongsheng Deng, 2011. Evaluating Conditions in Major Chinese Housing Markets, Regional Science and Urban Economics, forthcoming. 


\section{Table 1 Comparing financial systems: Banks and Markets (average 2001-2007)}

This table compares financial markets and banking sector of China with those of other large emerging economies. All the measures on the size and efficiency of banks and markets are based on Levine (2002) and Demirgüç-Kunt and Levine (2001), and data is from the World Bank Financial Database. We present the 2001-2007 average figures for all countries (except for "Structure Regulatory," which are based on 2005 figures). Average of other emerging economies are (simple) averages across other emerging economies excluding China.

\begin{tabular}{|c|c|c|c|c|c|c|c|c|c|c|c|}
\hline \multirow[b]{2}{*}{ Measures } & \multicolumn{4}{|c|}{ Size of Banks and Markets } & \multicolumn{4}{|c|}{ Structure Indices: Markets vs. banks* } & \multicolumn{3}{|c|}{$\begin{array}{c}\text { Financial Development } \\
\text { (banking and market sectors) }\end{array}$} \\
\hline & $\begin{array}{r}\text { Bank } \\
\text { credit/ } \\
\text { GDP }\end{array}$ & $\begin{array}{r}\text { NPL/ } \\
\text { Total } \\
\text { Loans }\end{array}$ & $\begin{array}{c}\text { Value } \\
\text { traded } \\
\text { /GDP }\end{array}$ & $\begin{array}{r}\text { Market } \\
\text { cap. } \\
\text { /GDP }\end{array}$ & $\begin{array}{r}\text { Structure } \\
\text { Activity }\end{array}$ & $\begin{array}{r}\text { Structure } \\
\text { Size }\end{array}$ & $\begin{array}{r}\text { Structure } \\
\text { Efficiency }\end{array}$ & $\begin{array}{r}\text { Structure } \\
\text { Regulatory }\end{array}$ & $\begin{array}{l}\text { Finance } \\
\text { Activity }\end{array}$ & $\begin{array}{r}\text { Finance } \\
\text { Size }\end{array}$ & $\begin{array}{r}\text { Finance } \\
\text { Efficiency }\end{array}$ \\
\hline China & 1.16 & 0.16 & 0.62 & 0.64 & -0.62 & 8.88 & 2.32 & 16 & 8.88 & 8.91 & 5.97 \\
\hline Argentina & 0.14 & 0.10 & 0.04 & 0.48 & -1.32 & 3.93 & 1.59 & 7 & 3.93 & 6.50 & 3.60 \\
\hline Brazil & 0.34 & 0.04 & 0.19 & 0.53 & -0.61 & 6.45 & 0.72 & 10 & 6.45 & 7.49 & 6.17 \\
\hline Egypt & 0.52 & 0.21 & 0.19 & 0.60 & -1.02 & 6.88 & 2.54 & 13 & 6.88 & 8.04 & 4.48 \\
\hline India & 0.37 & 0.07 & 0.57 & 0.64 & 0.44 & 7.65 & 1.50 & 10 & 7.65 & 7.76 & 6.71 \\
\hline Indonesia & 0.24 & 0.12 & 0.12 & 0.28 & -0.69 & 5.66 & 1.23 & $\mathrm{n} / \mathrm{a}$ & 5.66 & 6.51 & 4.60 \\
\hline Malaysia & 1.15 & 0.12 & 0.43 & 1.45 & -0.98 & 8.51 & 2.85 & 10 & 8.51 & 9.72 & 5.89 \\
\hline Mexico & 0.18 & 0.03 & 0.06 & 0.26 & -0.99 & 4.74 & -0.26 & 12 & 4.74 & 6.11 & 5.38 \\
\hline Pakistan & 0.26 & 0.14 & 0.72 & 0.28 & 1.01 & 7.55 & 1.36 & 10 & 7.55 & 6.61 & 6.26 \\
\hline Peru & 0.21 & 0.08 & 0.03 & 0.44 & -1.96 & 4.10 & 1.22 & 8 & 4.10 & 6.81 & 3.63 \\
\hline Philippines & 0.34 & 0.15 & 0.07 & 0.47 & -1.54 & 5.50 & 1.97 & 7 & 5.50 & 7.36 & 3.85 \\
\hline Russian & 0.26 & 0.04 & 0.27 & 0.65 & 0.06 & 6.54 & 0.96 & $\mathrm{n} / \mathrm{a}$ & 6.54 & 7.41 & 6.52 \\
\hline S. Africa & 1.38 & 0.02 & 0.88 & 2.06 & -0.45 & 9.40 & 1.43 & 8 & 9.40 & 10.25 & 8.38 \\
\hline Sri Lanka & 0.31 & 0.15 & 0.03 & 0.18 & -2.33 & 4.52 & 1.00 & 7 & 4.52 & 6.31 & 2.97 \\
\hline Thailand & 1.02 & 0.11 & 0.50 & 0.63 & -0.72 & 8.52 & 1.95 & 9 & 8.52 & 8.77 & 6.10 \\
\hline Turkey & 0.20 & 0.10 & 0.39 & 0.28 & 0.67 & 6.65 & 1.05 & 12 & 6.65 & 6.32 & 5.93 \\
\hline $\begin{array}{l}\text { Ave. for } \\
\text { EMs }\end{array}$ & 0.46 & 0.10 & 0.30 & 0.62 & -0.70 & 6.44 & 1.41 & 9.46 & 6.44 & 7.46 & 5.36 \\
\hline
\end{tabular}

Notes: *: Structure indices measure whether a country’s financial system is market- or bank-dominated; the higher the measure, the more the system is dominated by markets. Specifically, "structure activity" is equal to $\log ($ value traded/bank credit) and measures size of bank credit relative to trading volume of markets; "structure size” is equal to $\log$ (market cap/bank credit) and measures the size of markets relative to banks; "structure efficiency" is equal to log(market cap ratio×bank NPL ratio) and measures the relative efficiency of markets vs. banks; finally, "structure regulatory" is the sum of the four categories in regulatory restriction, or the degree to which commercial banks are allowed to engage in security, firm operation, insurance, and real estate: 1- unrestricted; 2-permit to conduct through subsidiary; 3-full range not permitted in subsidiaries; and 4-strictly prohibited.

**: Financial development variables measure the entire financial system (banking and market sectors combined), and the higher the measure, the larger or more efficient the financial system is. Specifically, "finance activity" is equal to log (total value traded ratio×private credit ratio), "finance size" is equal to log (market cap ratio×bank private credit ratio), and "finance efficiency” is equal to log (total value traded ratio/bank NPL ratio). 
Table 2-A Comparisons of Total Savings and Deposits (in US\$ billions)

\begin{tabular}{|c|c|c|c|c|c|c|c|c|c|c|c|c|}
\hline & 1998 & 1999 & 2000 & 2001 & 2002 & 2003 & 2004 & 2005 & 2006 & 2007 & 2008 & 2009 \\
\hline \multicolumn{13}{|c|}{ China } \\
\hline Demand deposits $^{\mathrm{a}}$ & 320 & 391 & 465 & 533 & 647 & 777 & 899 & 1030 & 1265 & 1671 & 1931 & 2683 \\
\hline Savings deposits ${ }^{\mathrm{b}}$ & 606 & 674 & 722 & 820 & 961 & 1143 & 1445 & 1748 & 2069 & 2363 & 3187 & 3811 \\
\hline Time deposits ${ }^{c}$ & 100 & 114 & 136 & 171 & 199 & 253 & 307 & 410 & 676 & 878 & 1205 & 1661 \\
\hline Time \& Savings Dep/GDP & $68 \%$ & $73 \%$ & $72 \%$ & $75 \%$ & $80 \%$ & $85 \%$ & $91 \%$ & $95 \%$ & $101 \%$ & $92 \%$ & $100 \%$ & $114 \%$ \\
\hline \multicolumn{13}{|c|}{ Japan } \\
\hline Demand deposits $^{\mathrm{a}}$ & 1793 & 2259 & 2073 & 1838 & 2567 & 3523 & 3795 & 3541 & 3523 & 3683 & 4560 & - \\
\hline $\begin{array}{l}\text { Time, savings \& foreign } \\
\text { currency deposits }\end{array}$ & 7921 & 8997 & 8059 & 5351 & 5383 & 5416 & 5448 & 4642 & 4536 & 4778 & 6160 & - \\
\hline Time \& Savings Dep/GDP & $181 \%$ & $185 \%$ & $184 \%$ & $142 \%$ & $131 \%$ & $118 \%$ & $114 \%$ & $109 \%$ & $106 \%$ & $106 \%$ & $110 \%$ & - \\
\hline \multicolumn{13}{|c|}{ South Korea } \\
\hline Demand deposits $^{\mathrm{a}}$ & 18 & 22 & 23 & 27 & 36 & 38 & 46 & 54 & 67 & 66 & 50 & 63 \\
\hline $\begin{array}{l}\text { Time, savings \& foreign } \\
\text { currency deposits }\end{array}$ & 185 & 251 & 289 & 315 & 383 & 410 & 467 & 485 & 546 & 543 & 471 & 574 \\
\hline Time \& Savings Dep/GDP & $46 \%$ & $54 \%$ & $61 \%$ & $64 \%$ & $63 \%$ & $64 \%$ & $58 \%$ & $57 \%$ & $56 \%$ & $52 \%$ & $58 \%$ & $63 \%$ \\
\hline \multicolumn{13}{|c|}{ India } \\
\hline Demand deposits $^{\mathrm{a}}$ & 24 & 28 & 31 & 32 & 35 & 44 & 60 & 71 & 89 & 114 & 96 & 119 \\
\hline $\begin{array}{l}\text { Time, savings \& foreign } \\
\text { currency deposits }\end{array}$ & 140 & 161 & 175 & 198 & 235 & 277 & 333 & 368 & 460 & 647 & 653 & 800 \\
\hline Time \& Savings Dep/GDP & $34 \%$ & $36 \%$ & $39 \%$ & $42 \%$ & $46 \%$ & $46 \%$ & $46 \%$ & $46 \%$ & $49 \%$ & $54 \%$ & $59 \%$ & $60 \%$ \\
\hline
\end{tabular}

Source: IMF and CEIC database

Notes: a : Demand deposits, balance of the accounts can be withdrawn on demand of customers (e.g., check-writing); ${ }^{\text {b: }}$

Savings deposits, interest-bearing accounts that can be withdrawn but cannot be used as Money (e.g., no checking

writing); ${ }^{c}$ : Time deposits, savings accounts or $\mathrm{CD}$ with a fixed term.

Table 2-B Breakdown of Bank Loans (end-of-year figures in RMB billions)

\begin{tabular}{rrrrrrrrrr}
\hline Year & $\begin{array}{r}\text { Total } \\
\text { Loans }\end{array}$ & $\begin{array}{r}\text { Short-term } \\
\text { Loans }\end{array}$ & $\begin{array}{r}\text { Industrial } \\
\text { Loans }\end{array}$ & $\begin{array}{r}\text { Commercial } \\
\text { Loans }\end{array}$ & $\begin{array}{r}\text { Infrastructure } \\
\text { Construction } \\
\text { Loans }\end{array}$ & $\begin{array}{r}\text { Agricultural } \\
\text { Loans }\end{array}$ & $\begin{array}{r}\text { Loans to } \\
\text { TVEs }\end{array}$ & $\begin{array}{r}\text { Privately } \\
\text { Owned } \\
\text { Firms }\end{array}$ & $\begin{array}{r}\text { Joint Ventures } \\
\text { \& Cooperative } \\
\text { Firms }\end{array}$ \\
\hline 1994 & $3,997.60$ & $2,694.87$ & 994.83 & $1,050.98$ & 61.72 & 114.39 & 200.24 & 15.59 & 79.23 \\
1995 & $5,054.41$ & $3,337.20$ & $1,177.47$ & $1,283.71$ & 79.93 & 154.48 & 251.49 & 19.62 & 99.91 \\
1996 & $6,115.66$ & $4,021.00$ & $1,421.33$ & $1,533.26$ & 97.38 & 191.91 & 282.19 & 27.98 & 134.63 \\
1997 & $7,491.41$ & $5,541.83$ & $1,652.66$ & $1,835.66$ & 159.11 & 331.46 & 503.58 & 38.67 & 189.10 \\
1998 & $8,652.41$ & $6,061.32$ & $1,782.15$ & $1,975.24$ & 162.87 & 444.42 & 558.00 & 47.16 & 248.75 \\
1999 & $9,373.43$ & $6,388.76$ & $1,794.89$ & $1,989.09$ & 147.69 & 479.24 & 616.13 & 57.91 & 298.58 \\
2000 & $9,937.11$ & $6,574.81$ & $1,701.93$ & $1,786.85$ & 161.71 & 488.90 & 606.08 & 65.46 & 304.98 \\
2001 & $11,231.47$ & $6,732.72$ & $1,863.67$ & $1,856.34$ & 209.96 & 571.15 & 641.30 & 91.80 & 326.35 \\
2002 & $13,129.39$ & $7,424.79$ & $2,019.05$ & $1,797.31$ & 274.80 & 688.46 & 681.23 & 105.88 & 269.74 \\
2003 & $15,899.62$ & $8,366.12$ & $2,275.60$ & $1,799.44$ & 300.21 & 841.14 & 766.16 & 146.16 & 256.94 \\
2004 & $17,819.78$ & $8,684.06$ & $2,389.66$ & $1,707.41$ & 278.01 & 984.31 & 806.92 & 208.16 & 219.84 \\
2005 & $19,469.04$ & $8,744.92$ & $2,251.67$ & $1,644.76$ & 298.37 & $1,152.99$ & 790.18 & 218.08 & 197.53 \\
2006 & $22,534,72$ & $9,853.44$ & $2,865.4$ & $1,667.15$ & 361.26 & $1,320.82$ & 622.20 & 266.76 & 183.27 \\
2007 & $26,169.09$ & $11,447.79$ & $3,362.33$ & $1,783.33$ & 374.19 & $1,542.93$ & 711.26 & 350.77 & 206.91 \\
2008 & $30,339.46$ & $12,518.17$ & $3,614.29$ & $1,773.22$ & 368.46 & $1,762.88$ & 745.4 & 422.38 & 227.08 \\
2009 & $39,968,48$ & $14,661,13$ & $3,876,92$ & $1,948,33$ & 364,68 & $2,162,25$ & 902,9 & 712,10 & 218,03 \\
\hline
\end{tabular}

Source: Statistical Yearbooks of China, CEIC database (1985 - 2009). 


\section{Table 3-A A Comparison of Non-performing Loans (NPLs) and Government Debt}

This table compares total outstanding NPLs within the banking system, government debt, and the ratio of (NPLs + Government Debt)/GDP among China, the U.S., and other major Asian countries for the period 1997-2010. Panel A presents the size of the NPLs, as measured by US\$ billion and as the percentage of GDPs in the same year. NPLs in the U.S. measure the outstanding “delinquency loan”; NPLs in Japan measure the "risk management loans" (or loans disclosed under the Financial Reconstructed Law and/or loans subject to self-assessment). In Panel B, outstanding government debt is measured at the end of each year; for the U.S. and Japan, total government debt includes domestic and foreign debt. In Panel C, the ratios for China include using the official NPL numbers and using doubled official NPLs (i.e., the ratios in the brackets are (doubled NPLs + government debt)/GDP); the ratios in the brackets for the U.S. and Japan are (net government debt + NPLs)/GDP, where net government debt is the difference between government borrowing (stock measure) and government lending (flow measure). All figures are converted into U.S. dollars using the average exchange rate within the observation year.

\begin{tabular}{|c|c|c|c|c|c|c|c|c|c|c|c|c|c|}
\hline Year & & China & & U.S. & Japan & & Korea & & India & \multicolumn{2}{|c|}{ Indonesia } & \multicolumn{2}{|r|}{ Taiwan } \\
\hline \multicolumn{14}{|c|}{ Panel A: Size of NPLs: In US\$ billion and as percentage of GDPs in the same year (in brackets) } \\
\hline & & -- & 66.9 & $(0.8 \%)$ & $217.4 \quad(5.1 \%)$ & 16.2 & (3.1\%) & & -- & 0.2 & $(0.1 \%)$ & 19.6 & $(6.5 \%)$ \\
\hline 1998 & 20.5 & $(2.0 \%)$ & 71.3 & $(0.8 \%)$ & 489.7 (12.7\%) & 23.2 & (6.7\%) & 12.7 & (3.1\%) & 5.5 & $(5.2 \%)$ & 21.8 & $(7.9 \%)$ \\
\hline 1999 & 105.1 & (9.7\%) & 72.2 & $(0.8 \%)$ & $547.6(12.6 \%)$ & 54.4 & (12.2\%) & 14.0 & (3.2\%) & 3.2 & (3.8\%) & 27.2 & (9.1\%) \\
\hline 2000 & 269.3 & (22.5\%) & 90.1 & $(0.9 \%)$ & $515.4(11.1 \%)$ & 35.5 & $(6.9 \%)$ & 12.9 & $(2.8 \%)$ & 6.3 & $(2.7 \%)$ & 33.2 & $(10.3 \%)$ \\
\hline 2001 & 265.3 & (20.0\%) & 108.4 & $(1.1 \%)$ & $640.1(15.6 \%)$ & 12.2 & $(2.5 \%)$ & 13.2 & $(2.8 \%)$ & 4.3 & $(1.7 \%)$ & 37.9 & $(13.0 \%)$ \\
\hline 2002 & 188.4 & (13.0\%) & 107.8 & $(1.0 \%)$ & 552.5 (14.1\%) & 9.9 & $(1.8 \%)$ & 14.8 & (3.0\%) & 3.3 & $(2.0 \%)$ & 30.7 & (10.4\%) \\
\hline 2003 & 181.2 & (11.0\%) & 95.9 & $(1.0 \%)$ & 480.1 (11.3\%) & 11.7 & $(1.9 \%)$ & 14.6 & (2.5\%) & 4.7 & $(1.5 \%)$ & 23.1 & $(7.7 \%)$ \\
\hline 2004 & 207.4 & (10.7\%) & 81.3 & $(0.9 \%)$ & $334.8 \quad(7.3 \%)$ & 10.0 & $(1.5 \%)$ & 14.4 & $(2.2 \%)$ & 3.8 & $(2.1 \%)$ & 26.4 & $(5.1 \%)$ \\
\hline 2005 & 164.2 & $(7.3 \%)$ & 84.6 & $(0.7 \%)$ & $183.3(4.0 \%)$ & 7.6 & $(1.0 \%)$ & 13.4 & $(1.7 \%)$ & 6.0 & $(1.5 \%)$ & 11.2 & $(3.2 \%)$ \\
\hline 2006 & 157.4 & $(5.9 \%)$ & 103.8 & $(0.8 \%)$ & $157.8 \quad(3.6 \%)$ & 8.2 & $(0.9 \%)$ & 11.2 & $(1.3 \%)$ & 5.2 & $(1.4 \%)$ & 11.3 & $3.1 \%$ \\
\hline 2007 & 166.8 & $(5.1 \%)$ & 168.1 & $(1.2 \%)$ & $148.6 \quad(3.4 \%)$ & 8.3 & $(0.8 \%)$ & 13.6 & $(1.2 \%)$ & 4.5 & $(1.0 \%)$ & 10.0 & $2.6 \%$ \\
\hline 2008 & 80.6 & $(1.9 \%)$ & 328.7 & $(2.3 \%)$ & 190.8 (3.7\%) & 13.0 & $(1.4 \%)$ & 15.4 & $(1.3 \%)$ & 4.3 & $(0.8 \%)$ & 9.0 & $2.3 \%$ \\
\hline 2009 & 72.6 & $(1.5 \%)$ & 477.5 & (3.3\%) & $188.45(3.63 \%)$ & 13.9 & $(1.5 \%)$ & 18.2 & $(1.3 \%)$ & 4.6 & $(1.0 \%)$ & 6.7 & $(1.8 \%)$ \\
\hline 2010 & 68.1 & $(1.1 \%)$ & 423.4 & $(2.9 \%)$ & $208.70(3.82 \%)$ & 26.8 & $(2.6 \%$ & 20.7 & $(1.2 \%)$ & 4.3 & $(0.6 \%)$ & 3.8 & $(0.9 \%)$ \\
\hline \multicolumn{14}{|c|}{ Panel B: Outstanding Government Debt (\$ billion) } \\
\hline & $\begin{array}{l}\text { Out } \\
\text { Gov }\end{array}$ & $\begin{array}{r}\text { standing } \\
\text { rernment } \\
\text { Bond } \\
\end{array}$ & Gov & $\begin{array}{r}\text { Total } \\
\text { ernment } \\
\text { Debt } \\
\end{array}$ & $\begin{array}{r}\text { Total } \\
\text { Government } \\
\text { Debt }\end{array}$ & Out & $\begin{array}{r}\text { standing } \\
\text { Treasury } \\
\text { Bonds } \\
\end{array}$ & Tota & $\begin{array}{r}\text { Public } \\
\text { Debt } \\
\end{array}$ & & $\begin{array}{r}\text { tanding } \\
\text { ernment } \\
\text { Bond } \\
\end{array}$ & $\begin{array}{l}\text { Out } \\
\text { Gov }\end{array}$ & $\begin{array}{r}\text { tstanding } \\
\text { vernment } \\
\text { Bond } \\
\end{array}$ \\
\hline 1997 & & 66.5 & & 802.8 & $4,254.0$ & & 5.3 & -- & & & & & \\
\hline 1998 & & 93.8 & & 788.8 & $4,858.0$ & & 14.4 & & 178.4 & & & & \\
\hline 1999 & & 127.3 & & 822.7 & $6,053.1$ & & 28.5 & & 260.2 & & 34.1 & & 46.5 \\
\hline 2000 & & 165.1 & & 612.7 & $6,209.8$ & & 32.7 & & 232.4 & & 45.1 & & 45.5 \\
\hline 2001 & & 188.6 & & 734.4 & $6,036.0$ & & 39.8 & & 225.4 & & 43.5 & & 58.7 \\
\hline 2002 & & 233.5 & & 169.4 & $6,321.3$ & & 45.2 & & 250.2 & & 42.1 & & 77.7 \\
\hline 2003 & & 273.0 & & 789.7 & $6,852.9$ & & 67.9 & & 259.7 & & 48.0 & & 75.7 \\
\hline 2004 & & 311.3 & & 335.6 & $7,446.6$ & & 107.0 & & 299.6 & & 44.7 & & 85.2 \\
\hline 2005 & & 350.0 & & 809.5 & $8,299.5$ & & 165.5 & & 347.1 & & 39.9 & & 86.7 \\
\hline 2006 & & 364.6 & & 451.4 & $7,587.1$ & & 216.7 & & 375.2 & & 45.7 & & 85.8 \\
\hline 2007 & & 599.8 & & 950.7 & $7,707.7$ & & 245.0 & & 472.0 & & 51.8 & & 94.5 \\
\hline 2008 & & 701.6 & & 985.8 & $8,966.2$ & & 217.8 & & 496.4 & & 52.8 & & 90.4 \\
\hline 2009 & & 753.6 & & 867.5 & $9,466.8$ & & 290.9 & & 556.6 & & 52.5 & & 82.9 \\
\hline 2010 & & 805.3 & & 551.8 & $11,284.9$ & & 364.0 & & 643.6 & & 68.4 & & 102.0 \\
\hline
\end{tabular}

Panel C: (NPLs + Outstanding Government Debt)/GDP

\begin{tabular}{rrrrrrrrrr}
\hline & -- & 0.71 & $(0.54)$ & 1.05 & $(0.40)$ & 0.04 & -- & -- \\
1998 & 0.11 & 0.67 & $(0.50)$ & 1.39 & $(0.63)$ & 0.11 & 0.46 & --
\end{tabular}




\begin{tabular}{llllllllll}
1999 & 0.21 & 0.64 & $(0.45)$ & 1.51 & $(0.64)$ & 0.19 & 0.62 & 0.24 & 0.25 \\
2000 & 0.36 & 0.58 & $(0.40)$ & 1.45 & $(0.65)$ & 0.13 & 0.53 & 0.31 & 0.24 \\
2001 & 0.34 & 0.58 & $(0.39)$ & 1.63 & $(0.83)$ & 0.11 & 0.50 & 0.30 & 0.33 \\
2002 & 0.29 & 0.60 & $(0.42)$ & 1.76 & $(0.90)$ & 0.10 & 0.54 & 0.23 & 0.37 \\
2003 & 0.28 & 0.63 & $(0.45)$ & 1.73 & $(0.86)$ & 0.13 & 0.48 & 0.22 & 0.33 \\
2004 & 0.27 & 0.63 & $(0.46)$ & 1.70 & $(0.81)$ & 0.17 & 0.47 & 0.19 & 0.32 \\
2005 & 0.23 & 0.63 & $(0.47)$ & 1.86 & $(0.84)$ & 0.22 & 0.47 & 0.16 & 0.27 \\
2006 & 0.20 & 0.65 & $(0.44)$ & 1.78 & $(0.88)$ & 0.24 & 0.44 & 0.14 & 0.26 \\
2007 & 0.23 & 0.66 & $(0.45)$ & 1.79 & $(0.89)$ & 0.24 & 0.44 & 0.13 & 0.27 \\
2008 & 0.18 & 0.72 & $(0.50)$ & 1.78 & $(0.88)$ & 0.25 & 0.42 & 0.11 & 0.25 \\
2009 & 0.17 & 0.94 & $(0.46)$ & 1.55 & $(1.15)$ & 0.24 & 0.58 & 0.11 & 0.24 \\
2010 & 0.21 & 1.01 & $(0.70)$ & 1.94 & $(1.20)$ & 0.33 & 0.45 & 0.10 & 0.25 \\
\hline
\end{tabular}

Sources: Statistical Bureau of China, the People’s Bank of China, Chinese Banking Regulatory Commission; Board of Governors of the Federal Reserve Bank, Statistical Abstracts of the U.S., the Statistical Bureau of Japan; Ministry of Finance, Korea, the Bank of Korea, Korean Statistical Information System; IMF, World Bank; Bank Indonesia; Ministry of Finance, India; National Statistical Bureau of Taiwan, Bloomberg, Chinabond, and Taiwan financial supervisory commission.

\section{Table 3-B Liquidation of NPLs by Four Asset Management Companies (RMB billion)}

This table presents results on the liquidation of NPLs by four state-owned asset management companies in China during the period 2001 to the $1^{\text {st }}$ quarter of 2006. These asset management companies were set up to specifically deal with NPLs accumulated in the 'Big Four' state-owned banks.

\begin{tabular}{|c|c|c|c|c|c|}
\hline & $\begin{array}{r}\text { Book value of } \\
\text { Assets } \\
\text { (Accumulated) }\end{array}$ & $\begin{array}{r}\text { Assets } \\
\text { Recovered }\end{array}$ & $\begin{array}{r}\text { Cash } \\
\text { Recovered }\end{array}$ & $\begin{array}{r}\text { Asset Recovery } \\
\text { Rate (\%) }\end{array}$ & $\begin{array}{r}\text { Cash Recovery } \\
\text { Rate (\%) }\end{array}$ \\
\hline \multicolumn{6}{|c|}{2001} \\
\hline Hua Rong & 23.21 & 12.54 & 7.55 & 54.0 & 32.5 \\
\hline Great Wall & 53.11 & 6.30 & 3.69 & 11.9 & 6.9 \\
\hline Oriental & 18.29 & 8.51 & 4.42 & 46.5 & 24.2 \\
\hline Xin Da & 29.90 & 22.50 & 10.49 & 75.3 & 35.1 \\
\hline Total & 124.51 & 49.86 & 26.15 & 40.0 & 21.0 \\
\hline \multicolumn{6}{|c|}{2002} \\
\hline Hua Rong & 32.04 & 11.43 & 10.20 & 35.7 & 31.8 \\
\hline Great Wall & 45.48 & 7.94 & 5.47 & 17.5 & 12.0 \\
\hline Oriental & 22.10 & 10.60 & 5.57 & 47.9 & 25.2 \\
\hline Xin Da & 33.10 & 17.46 & 10.51 & 52.7 & 31.8 \\
\hline Total & 132.73 & 47.43 & 31.75 & 35.7 & 23.9 \\
\hline \multicolumn{6}{|c|}{2004} \\
\hline & $\begin{array}{r}\text { Accumulated } \\
\text { Disposal }\end{array}$ & $\begin{array}{r}\text { Cash } \\
\text { Recovered }\end{array}$ & $\begin{array}{r}\text { Disposal } \\
\text { Ratio (\%) }\end{array}$ & $\begin{array}{r}\text { Asset Recovery } \\
\text { Ratio (\%) }\end{array}$ & $\begin{array}{r}\text { Cash Recovery } \\
\text { Ratio (\%) }\end{array}$ \\
\hline Hua Rong & 209.54 & 41.34 & 59.77 & 25.29 & 19.73 \\
\hline Great Wall & 209.91 & 21.57 & 61.91 & 14.43 & 10.27 \\
\hline Oriental & 104.55 & 23.29 & 41.42 & 29.50 & 22.27 \\
\hline Xin Da & 151.06 & 50.81 & 48.90 & 38.29 & 33.64 \\
\hline Total & 675.06 & 137.00 & 53.96 & 25.48 & 20.29 \\
\hline \multicolumn{6}{|c|}{2005} \\
\hline Hua Rong & 243.38 & 54.39 & 69.17 & 26.92 & 22.35 \\
\hline Great Wall & 263.39 & 27.35 & 77.88 & 12.90 & 10.39 \\
\hline
\end{tabular}




\begin{tabular}{lccccc}
\hline Oriental & 131.76 & 32.01 & 52.08 & 28.73 & 24.30 \\
Xin Da & 201.21 & 62.84 & 63.82 & 34.30 & 31.23 \\
Total & 839.75 & 176.60 & 66.74 & 24.58 & 21.03 \\
\hline \multicolumn{7}{c}{$\mathbf{2 0 0 6}(\mathbf{Q 1 )}$} \\
\hline Hua Rong & 246.80 & 54.66 & 70.11 & 26.50 & 22.15 \\
Great Wall & 270.78 & 27.83 & 80.11 & 12.70 & 10.28 \\
Oriental & 141.99 & 32.81 & 56.13 & 27.16 & 23.11 \\
Xin Da & 206.77 & 65.26 & 64.69 & 34.46 & 31.56 \\
Total & 866.34 & 180.56 & 68.61 & 24.20 & 20.84 \\
\hline
\end{tabular}

Notes: 1. Accumulated Disposal refers to the accumulated amount of cash and non-cash assets recovered as well as loss incurred by the end of the reporting period.

2. Disposal Ratio $=$ Accumulated Disposal $/$ Total NPLs purchased .

3. Asset Recovery Ratio = Total Assets Recovered $/$ Accumulated Disposal.

4. Cash Recovery Ratio $=$ Cash Recovered $/$ Accumulated Disposal.

Source: Almanac of China’s Finance and Banking 2002-2005, and the reports of China Banking Regulatory Commission 2004-2009.

\section{Table 4-A Chinese Banks’ IPOs and Comparison with Other Banks}

This table presents information on the IPOs of the Big Four banks and that of Bank of Communications (BComm). BOC, ICBC and ABC were listed in both the HKSE (HK dollar) and SHSE (RMB), while PCBC and BComm only listed shares on the HKSE. First day (first week) return is percentage return of closing price of first day (fifth trading day) over offer price. Foreign ownership indicates size of ownership stakes of foreign institutions and investors at the date of IPOs.

Panel A Performance of Chinese Banks' IPOs

\begin{tabular}{|c|c|c|c|c|c|c|c|c|}
\hline & \multicolumn{2}{|c|}{ ICBC } & \multicolumn{2}{|c|}{ BOC } & \multirow{2}{*}{$\begin{array}{l}\text { PCBC } \\
\text { HKSE } \\
(\mathrm{HK} \$)\end{array}$} & \multirow{2}{*}{$\begin{array}{c}\text { BComm } \\
\text { HKSE } \\
\text { (HK\$) }\end{array}$} & \multicolumn{2}{|c|}{ ABC* } \\
\hline & $\begin{array}{l}\text { HKSE } \\
(\mathrm{HK} \$)\end{array}$ & $\begin{array}{c}\text { SHSE } \\
\text { (RMB) }\end{array}$ & $\begin{array}{l}\text { HKSE } \\
(\mathrm{HK} \$)\end{array}$ & $\begin{array}{c}\text { SHSE } \\
\text { (RMB) }\end{array}$ & & & $\begin{array}{l}\text { HKSE } \\
(\mathrm{HK \$})\end{array}$ & $\begin{array}{c}\text { SHSE } \\
\text { (RMB) }\end{array}$ \\
\hline IPO Date & $10 / 27 / 2006$ & $10 / 27 / 2006$ & $6 / 01 / 2006$ & $7 / 05 / 2006$ & $10 / 27 / 2005$ & $6 / 23 / 2005$ & $7 / 15 / 2010$ & $7 / 16 / 2010$ \\
\hline Offer Price & 3.07 & 3.12 & 2.95 & 3.08 & 2.35 & 2.5 & 3.2 & 2.68 \\
\hline Proceeds & 124.95B & 46.64B & 82.86B & $20.00 \mathrm{~B}$ & 59.94B & 14.64B & 93.8B & 68.5B \\
\hline $1^{\text {st }}$ Day Return & $14.66 \%$ & $5.13 \%$ & $14.41 \%$ & $22.73 \%$ & $0.00 \%$ & $13.00 \%$ & $2.2 \%$ & $1 \%$ \\
\hline $1^{\text {st }}$ Week Return & $16.94 \%$ & $4.81 \%$ & $19.49 \%$ & $19.16 \%$ & $-1.06 \%$ & $13.00 \%$ & $9.1 \%$ & $1.9 \%$ \\
\hline Foreign Ownership & $7.28 \%$ & -- & $14.40 \%$ & -- & $14.39 \%$ & $18.33 \%$ & $40.8 \%$ & -- \\
\hline
\end{tabular}

Source: IPO prospectuses submitted to SHSE and HKSE; SHSE and HKSE.

*: In USD, ABC raised \$22.1 billion from its IPO, beating the record of \$21.9 billion from ICBC's IPO. However in terms of RMB, ICBC still holds the record of largest IPO since RMB has appreciated significantly since 2006.

Panel B Top 10 Banks Measured by Market Capitalization (\$billion)

\begin{tabular}{clcrr}
\hline Rank & Bank Name & $\begin{array}{c}\text { HQ } \\
\text { Country }\end{array}$ & $\begin{array}{c}\text { Market Cap. \$B } \\
\left(\text { July. 16 }^{\text {th }}, 2010\right)\end{array}$ & $\begin{array}{r}\text { Total Return (\%) } \\
\text { YTD }\end{array}$ \\
\hline 1 & IND \& COMM BK & China & 214.51 & -20.14 \\
2 & CHINA CONST BANK & China & 189.04 & -1.99 \\
3 & HSBC HLDGS PLC & U.K. & 166.51 & -15.40 \\
4 & JPMORGAN CHASE & U.S. & 155.17 & -6.06 \\
5 & BANK OF AMERICA & U.S. & 140.26 & -7.06 \\
6 & WELLS FARGO \& CO & U.S. & 136.71 & -2.46 \\
7 & BANK OF CHINA & China & 130.29 & 1.71 \\
8 & AGRICULTURAL BANK & China & 128.60 & 0.4
\end{tabular}




\begin{tabular}{clccr}
9 & CITIGROUP INC & US & 113.00 & 17.82 \\
10 & BANCO SANTANDER & Spain & 102.77 & -21.87 \\
\hline
\end{tabular}

Source: Bloomberg.

Panel C Top 20 Banks Measured by Total Assets (July 2010; \$trillion)

\begin{tabular}{rllr}
\hline Rank & Bank Name (HQ Country) & HQ Country & $\begin{array}{r}\text { Total Assets } \\
\text { (\$trillion) }\end{array}$ \\
\hline 1 & BNP PARIBAS & France & 2.95 \\
2 & ROYAL BANK SCOTLAN & UK & 2.68 \\
3 & HSBC HLDGS PLC & UK & 2.36 \\
4 & BANK OF AMERICA & U.S & 2.36 \\
5 & DEUTSCHE BANK-RG & Germany & 2.26 \\
6 & CREDIT AGRICOLE & France & 2.23 \\
7 & BARCLAYS PLC & U.K. & 2.23 \\
8 & MITSUBISHI UFJ F & Japan & 2.18 \\
9 & JPMORGAN CHASE & U.S. & 2.01 \\
10 & CITIGROUP INC & U.S. & 1.94 \\
$\mathbf{1 1}$ & IND \& COMM BANK & China & $\mathbf{1 . 7 3}$ \\
12 & MIZUHO FINANCIAL & Japan & 1.67 \\
13 & LLOYDS BANKING & U.K. & 1.66 \\
14 & BANCO SANTANDER & Spain & 1.55 \\
$\mathbf{1 5}$ & CHINA CONST BA-H & China & $\mathbf{1 . 4 8}$ \\
16 & SOC GENERALE & France & 1.47 \\
17 & SUMITOMO MITSUI & Japan & 1.32 \\
$\mathbf{1 8}$ & AGRICULTURAL BANK & China & $\mathbf{1 . 3 0}$ \\
19 & UBS AG-REG & Switzerland & 1.29 \\
20 & UNICREDIT SPA & Italy & 1.28 \\
\hline
\end{tabular}

Source: Bloomberg (based on latest filings), July 15th, 2010.

Table 4-B State-owned and Private Banks in China (RMB billion)

\begin{tabular}{|c|c|c|c|c|c|}
\hline Types of Banks & Total Assets & Total Deposits & Outstanding Loans & Profit $^{1}$ & NPL rate (\%) \\
\hline \multicolumn{6}{|c|}{2009} \\
\hline Big Five Banks & $40,089.0$ & $29,506.5$ & $20,151.7$ & 400.1 & 1.8 \\
\hline Other Commercial Banks & $17,465.0$ & $15,041.5$ & $9,606.6$ & & \\
\hline 1) Joint Equity & $11,785.0$ & $10,548.7$ & $6,707.4$ & 92.5 & 1.0 \\
\hline 2) City Commercial Banks & $5,680.0$ & $4,492.8$ & $2,899.2$ & 49.7 & 1.3 \\
\hline Foreign Banks & $1,349.2$ & 668.8 & 727.1 & 6.5 & 0.9 \\
\hline Urban Credit Cooperatives & 27.2 & 39.5 & & 0.2 & \\
\hline Rural Credit Cooperatives & $5,492.5$ & $4,742.1$ & $5,421.3$ & 22.8 & \\
\hline \multicolumn{6}{|c|}{2008} \\
\hline Big Five Banks & $31,836.0$ & $23,696.1$ & $15,029.3$ & 354.2 & 2.8 \\
\hline Other Commercial Banks & $12,941.2$ & $11,072.2$ & $7,162.4$ & & \\
\hline 1) Joint Equity & $8,809.2$ & $7,801.8$ & $5,054.5$ & 84.1 & 1.3 \\
\hline 2) City Commercial Banks & $4,132.0$ & $3,270.4$ & $2,107.9$ & 40.8 & 2.3 \\
\hline Foreign Banks & $1,344.8$ & 533.5 & 762.1 & 11.9 & 0.8 \\
\hline Urban Credit Cooperatives & 80.4 & 76.2 & & 0.62 & \\
\hline Rural Credit Cooperatives & $5,211.3$ & 4,173.6 & $3,753.2$ & 21.9 & \\
\hline \multicolumn{6}{|c|}{2007} \\
\hline Big Five Banks & $28,007.0$ & $20,067.7$ & $13,850.9$ & 246.6 & 8.05 \\
\hline
\end{tabular}




\begin{tabular}{|c|c|c|c|c|c|}
\hline Other Commercial Banks & $10,589.9$ & $9,023.3$ & $5,684.4$ & & \\
\hline 1) Joint Equity & $7,249.4$ & $6,432.0$ & $4,001.9$ & 56.4 & 2.15 \\
\hline 2) City Commercial Banks & $3,340.5$ & $2,591.4$ & $1,682.6$ & 24.8 & 3.04 \\
\hline Foreign Banks & $1,252.5$ & 390.0 & 700.0 & 6.1 & 0.46 \\
\hline Urban Credit Cooperatives & 131.2 & 134.1 & 84.7 & 0.77 & \\
\hline Rural Credit Cooperatives & $4,343.4$ & $3,534.9$ & $3,256.1$ & 19.3 & \\
\hline \multicolumn{6}{|c|}{2006} \\
\hline Big Five Banks & 24,236 & $18,285.1$ & $11,426.2$ & 197.5 & 9.22 \\
\hline Other Commercial Banks & $8,038.4$ & 7512.8 & 5526.6 & & \\
\hline 1) Joint Equity & $5,444.6$ & $5,396.5$ & $4,156.9$ & 43.4 & 2.81 \\
\hline 2) City Commercial Banks & $2,593.8$ & $2,116.2$ & $1,369.7$ & 18.1 & 4.78 \\
\hline Foreign Banks & 927.9 & 244.0 & 485.9 & 5.8 & 0.78 \\
\hline Urban Credit Cooperatives & 183.1 & 157.9 & 100.7 & 1.0 & \\
\hline Rural Credit Cooperatives & $3,450.3$ & $3,040.2$ & $2,747.6$ & 18.6 & \\
\hline \multicolumn{6}{|c|}{2005} \\
\hline Big Five Banks ${ }^{2}$ & $21,005.0$ & $16,283.8$ & $10,224.0$ & 156.1 & 10.49 \\
\hline Other Commercial Banks & $6,502.2$ & $6,261.1$ & 4,576.6 & & \\
\hline 1) Joint Equity & $4,465.5$ & $4,570.0$ & $3,487.7$ & 28.9 & 4.22 \\
\hline 2) City Commercial Banks & $2,036.7$ & $16,91.2$ & $1,088.9$ & 12.1 & 7.73 \\
\hline Foreign Banks & 715.5 & 179.3 & 363.8 & 3.7 & 1.05 \\
\hline Urban Credit Cooperatives & 203.3 & 181.3 & 113.1 & 0.9 & \\
\hline Rural Credit Cooperatives & $3,142.7$ & $2,767.4$ & 2,319.9 & 12.0 & \\
\hline \multicolumn{6}{|c|}{2004} \\
\hline Big Four Banks & $16,932.1$ & $14,412.3$ & $10,086.1$ & 45.9 & 15.57 \\
\hline Other Commercial Banks & 4,697.2 & 4,059.9 & 2,885.9 & 50.7 & 4.93 \\
\hline 1) Joint Equity & & & & 17.6 & 5.01 \\
\hline 2) City Commercial Banks & $1,693.8$ & $1,434.1$ & 904.5 & 8.5 & 11.73 \\
\hline Foreign Banks & 515.9 & 126.4 & 255.8 & 18.8 & 1.34 \\
\hline Urban Credit Cooperatives & 171.5 & 154.9 & 97.9 & 0.4 & \\
\hline Rural Credit Cooperatives & $3,101.3$ & 2,734.8 & $1,974.8$ & 9.65 & \\
\hline \multicolumn{6}{|c|}{2003} \\
\hline Big Four Banks & $16,275.1$ & $13,071.9$ & $9,950.1$ & 196.5 & 19.74 \\
\hline Other Commercial Banks & 3,816.8 & 3,286.5 & $2,368.2$ & & 7.92 \\
\hline 1) Joint Equity & & & & 14.6 & 6.5 \\
\hline 2) City Commercial Banks & $1,465.4$ & $1,174.7$ & 774.4 & 5.4 & 14.94 \\
\hline Foreign Banks & 333.1 & 90.7 & 147.6 & 18.1 & 2.87 \\
\hline Urban Credit Cooperatives & 148.7 & 127.1 & 85.6 & 0.01 & \\
\hline Rural Credit Cooperatives & $2,674.6$ & 2,376.5 & $1,775.9$ & 4.4 & \\
\hline \multicolumn{6}{|l|}{ (2) } \\
\hline Big Four Banks & $14,450.0$ & $11,840.0$ & $8,460.0$ & 71.0 & 26.1 \\
\hline Other Commercial Banks & $4,160.0$ & 3,390.0 & $2,290.0$ & -- & -- \\
\hline 1) Joint Equity & $2,990.0$ & -- & -- & -- & 9.5 \\
\hline 2) City Commercial Banks & $1,170.0$ & -- & -- & -- & 17.7 \\
\hline Foreign Banks & 324.2 & -- & 154.0 & 15.2 & -- \\
\hline Urban Credit Cooperatives & 119.0 & 101.0 & 66.4 & -- & \\
\hline Rural Credit Cooperatives & -- & $1,987.0$ & $1,393.0$ & -- & -- \\
\hline \multicolumn{6}{|c|}{2001} \\
\hline Big Four Banks & $13,000.0$ & $10,770.0$ & $7,400.0$ & 23.0 & 25.37 \\
\hline Other Commercial Banks & $3,259.0$ & $2,530.7$ & $1,649.8$ & 12.9 & -- \\
\hline 1) Joint Equity & $2,386.0$ & $1,849.0$ & $1,224.0$ & 10.5 & 12.94 \\
\hline 2) City Commercial Banks & 873.0 & 681.7 & 425.8 & 2.4 & -- \\
\hline Foreign Banks & 373.4 & -- & 153.2 & 1.7 & -- \\
\hline Urban Credit Cooperatives & 128.7 & 107.1 & 72.5 & 2.6 & -- \\
\hline Rural Credit Cooperatives & -- & $1,729.8$ & $1,197.0$ & -- & -- \\
\hline
\end{tabular}

Notes: 1. It is before tax profit up to 2006, and after tax profit from 2006-2009. 
2. Big four (stated owned) banks refer to Bank of China, China Construction Bank, Industrial and Commercial Bank of China, and Agricultural Bank of China. Big five banks are the Big four Banks and Bank of Communications.

Source: Almanac of China's Finance and Banking 2000-2008, CEIC data base, Quarterly Monetary Report of PBC.

\section{Table 4-C Comparison of Assets Held by China's Non-Bank Intermediaries (RMB billion)}

This table compares total assets held by banks and non-bank intermediaries during the period 1995-2009.

\begin{tabular}{rrrrrrrrr}
\hline Year & $\begin{array}{r}\text { State- } \\
\text { owned } \\
\text { Banks }\end{array}$ & RCCs & UCCs & $\begin{array}{r}\text { Insurance } \\
\text { Companies }\end{array}$ & TICs & $\begin{array}{r}\text { Non-deposit } \\
\text { Intermediaries }\end{array}$ & $\begin{array}{r}\text { Other } \\
\text { Commercial } \\
\text { Banks }\end{array}$ & $\begin{array}{r}\text { Foreign } \\
\text { Banks }\end{array}$ \\
\hline 1995 & $5,373.3$ & 679.10 & 303.92 & -- & 458.60 & 48.97 & 536.91 & 42.90 \\
1996 & $6,582.7$ & 870.66 & 374.78 & -- & 563.70 & 82.02 & 769.98 & 55.30 \\
1997 & $7,914.4$ & $1,012.20$ & 498.94 & -- & 636.40 & 100.42 & 948.61 & 75.80 \\
1998 & $8,860.9$ & $1,143.11$ & 560.63 & -- & 802.50 & 120.97 & $1,128.18$ & 118.40 \\
1999 & $9,970.6$ & $1,239.24$ & 630.15 & 260.4 & 907.50 & 137.08 & $1,376.89$ & 191.40 \\
2000 & $10,793.7$ & $1,393.06$ & 678.49 & 337.4 & 975.90 & 160.82 & $1,828.26$ & 379.20 \\
2001 & $11,188.2$ & $1,610.80$ & 780.02 & 459.1 & $1,088.30$ & 223.67 & $2,255.70$ & 341.80 \\
2002 & $13,549.6$ & $2,205.21$ & 119.23 & 649.4 & $1,544.10$ & 408.10 & $2,997.72$ & 317.90 \\
2003 & $16,275.1$ & $2,674.62$ & 148.72 & 912.3 & -- & 495.58 & $3,816.80$ & 331.10 \\
2004 & $16,932.1$ & $3,103.30$ & 171.50 & 1185.4 & -- & -- & $4,697.20$ & 515.90 \\
2005 & $21,005.0$ & $3,142.7$ & 203.3 & 1529.6 & -- & -- & $6,502.2$ & 715.5 \\
2006 & $24,23.0$ & $3,450.3$ & 183.1 & 1973.1 & -- & -- & $8,038.4$ & 927.9 \\
2007 & $28,007.0$ & $4,343.4$ & 131.2 & 2900.4 & -- & -- & $10,589.9$ & $1,252.5$ \\
2008 & $31,836.0$ & $5,211.3$ & 80.4 & 3341.8 & -- & -- & $12,941.2$ & $1,344.8$ \\
2009 & $40,089.0$ & $5,492.5$ & 27.2 & 4063.5 & & & $17,465.0$ & $1,349.2$ \\
\hline
\end{tabular}

Source: Aggregate Statistics from the People’s Bank of China (China’s Central Bank) and CEIC, 2000 - 2009.

Table 5-A A Comparison of the Largest Stock Markets in the World (01/01-12/31, 2010)

\begin{tabular}{lcccc}
\hline Rank & Stock Exchange & $\begin{array}{c}\text { Total Market Cap } \\
\text { (US\$ million) }\end{array}$ & $\begin{array}{c}\text { Concentration } \\
\mathbf{( \% )}\end{array}$ & $\begin{array}{c}\text { Turnover } \\
\text { Velocity (\%) }\end{array}$ \\
1 & NYSE Euronext (US) & $13,394,081.8$ & $57.0 \%$ & $130.2 \%$ \\
2 & NASDAQ OMX & $3,889,369.9$ & $71.9 \%$ & $340.4 \%$ \\
3 & Tokyo SE Group & $3,827,774.2$ & $60.1 \%$ & $109.6 \%$ \\
4 & London SE Group & $3,613,064.0$ & $82.3 \%$ & $76.1 \%$ \\
5 & NYSE Euronext (Europe) & $2,930,072.4$ & $68.9 \%$ & $76.5 \%$ \\
6 & Shanghai SE & $\mathbf{2 , 7 1 6 , 4 7 0 . 2}$ & $\mathbf{5 5 . 8 \%}$ & $\mathbf{1 7 8 . 5 \%}$ \\
7 & Hong Kong Exchanges & $\mathbf{2 , 7 1 1 , 3 1 6 . 2}$ & $\mathbf{6 9 . 4 \%}$ & $\mathbf{6 2 . 2 \%}$ \\
8 & TSX Group & $2,170,432.7$ & $79.5 \%$ & $18.1 \%$ \\
9 & Bombay SE & $1,631,829.5$ & $87.7 \%$ & $57.3 \%$ \\
10 & National Stock Exchange India & $1,596,625.3$ & $69.6 \%$ & $64.7 \%$ \\
11 & BM\&FBOVESPA & $1,545,565.7$ & $64.2 \%$ & $82.3 \%$ \\
12 & Australian Securities Exchange & $1,454,490.6$ & $79.4 \%$ & $119.3 \%$ \\
13 & Deutsche Börse & $1,429,719.1$ & $78.4 \%$ & $\mathbf{3 4 4 . 3 \%}$ \\
14 & Shenzhen SE & $\mathbf{1 , 3 1 1 , 3 7 0 . 1}$ & $\mathbf{3 1 . 2 \%}$ & $73.5 \%$ \\
15 & SIX Swiss Exchange & $1,229,356.5$ & $65.6 \%$ & $117.2 \%$ \\
16 & BME Spanish Exchanges & $1,171,625.0$ & NA & $176.3 \%$ \\
17 & Korea Exchange & $1,091,911.5$ & $75.7 \%$ & $79.7 \%$ \\
\hline 19 & NASDAQ OMX Nordic Exchange & $1,042,153.7$ & $69.7 \%$ & $52.8 \%$ \\
\hline
\end{tabular}


Notes: All figures are from http//:www.world-exchanges.org, the web site of the international organization of stock exchanges. Concentration is the fraction of total turnover of an exchange within a year coming from the turnover of the companies with the largest market cap (top 5\%). Turnover velocity is the total turnover of domestic stocks for the year expressed as a percentage of the total market capitalization.

\section{Table 5-B China’s Bond Markets: 1990 - 2009 (Amount in RMB billion)}

This table presents the development of China’s bond markets. "Policy Financial Bonds” are issued by "policy banks," which belong to the Treasury Department, and the proceeds of bond issuance are invested in government run projects and industries such as infrastructure construction (similar to municipal bonds in the U.S.)

\begin{tabular}{|c|c|c|c|c|c|c|c|c|c|}
\hline \multirow[b]{2}{*}{ Year } & \multicolumn{3}{|c|}{ Treasury Bonds } & \multicolumn{3}{|c|}{ Policy Financial Bonds } & \multicolumn{3}{|c|}{ Corporate Bonds } \\
\hline & $\begin{array}{r}\text { Amount } \\
\text { Issued }\end{array}$ & $\begin{array}{r}\text { Redemption } \\
\text { Amount }\end{array}$ & Balance & $\begin{array}{r}\text { Amount } \\
\text { Issued }\end{array}$ & $\begin{array}{r}\text { Amounts } \\
\text { Redemption }\end{array}$ & Balance & $\begin{array}{r}\text { Amounts } \\
\text { issued }\end{array}$ & $\begin{array}{r}\text { Amounts } \\
\text { Redemption }\end{array}$ & Balance \\
\hline 1990 & 19.72 & 7.62 & 89.03 & 6.44 & 5.01 & 8.49 & 12.4 & 7.73 & 19.54 \\
\hline 1991 & 28.13 & 11.16 & 106.00 & 6.69 & 3.37 & 11.81 & 24.9 & 11.43 & 33.11 \\
\hline 1992 & 46.08 & 23.81 & 128.27 & 5.50 & 3.00 & 14.31 & 68.37 & 19.28 & 82.20 \\
\hline 1993 & 38.13 & 12.33 & 154.07 & 0.00 & 3.43 & 10.88 & 23.58 & 25.55 & 80.24 \\
\hline 1994 & 113.76 & 39.19 & 228.64 & 0.00 & 1.35 & 9.53 & 16.18 & 28.20 & 68.21 \\
\hline 1995 & 151.09 & 49.70 & 330.03 & -- & -- & 170.85 & 30.08 & 33.63 & 64.66 \\
\hline 1996 & 184.78 & 78.66 & 436.14 & 105.56 & 25.45 & 250.96 & 26.89 & 31.78 & 59.77 \\
\hline 1997 & 241.18 & 126.43 & 550.89 & 143.15 & 31.23 & 362.88 & 25.52 & 21.98 & 52.10 \\
\hline 1998 & 380.88 & 206.09 & 776.57 & 195.02 & 32.04 & 512.11 & 15.00 & 10.53 & 67.69 \\
\hline 1999 & 401.50 & 123.87 & $1,054.20$ & 180.09 & 47.32 & 644.75 & 15.82 & 5.65 & 77.86 \\
\hline 2000 & 465.70 & 152.50 & $1,367.40$ & 164.50 & 70.92 & 738.33 & 8.30 & 0.00 & 86.16 \\
\hline 2001 & 488.40 & 228.60 & $1,561.80$ & 259.00 & 143.88 & 853.45 & 14.70 & 0.00 & 100.86 \\
\hline 2002 & 593.43 & 226.12 & $1,933.60$ & 307.50 & 155.57 & $1,005.41$ & 32.50 & 0.00 & 133.36 \\
\hline 2003 & 628.01 & 275.58 & $2,260.36$ & 456.14 & 250.53 & $1,165.00$ & 35.80 & 0.00 & 169.16 \\
\hline 2004 & 692.39 & 374.99 & $2,577.76$ & 414.80 & 177.87 & $1,401.93$ & 32.70 & 0.00 & 201.86 \\
\hline 2005 & 704.20 & 404.55 & $2,877.40$ & 585.17 & 205.30 & $1,781.80$ & 204.65 & 3.70 & 401.81 \\
\hline 2006 & 888.33 & 620.86 & 3144.87 & 898.00 & 379.0 & $2,300.80$ & 393.83 & 167.24 & 553.29 \\
\hline 2007 & 2313.91 & 584.68 & 4874.10 & 1109.02 & 413.36 & 2992.68 & 505.85 & 288.09 & 768.33 \\
\hline 2008 & 855.82 & 753.14 & 4976.78 & 1082.30 & 406.38 & 3668.6 & 843.54 & 327.78 & 1285.06 \\
\hline 2009 & 1792.7 & 707.15 & -- & 1167.8 & -- & -- & 1662.9 & 440.0 & -- \\
\hline $\begin{array}{l}\text { Yearly } \\
\text { Growth }\end{array}$ & $25.3 \%$ & $24.4 \%$ & $25.0 \%$ & $29.7 \%$ & $27.7 \%$ & $40.1 \%$ & $25.5 \%$ & $22.3 \%$ & $26.2 \%$ \\
\hline
\end{tabular}

Source: Aggregate Statistics from the People’s Bank of China (China’s Central Bank) 2000 - 2009 and the Statistical Yearbook of China 2000-2009. 
Table 6-A Types of Common Stock Issued in China

\begin{tabular}{|c|c|c|}
\hline \multicolumn{2}{|c|}{ Tradable? } & Definition \\
\hline \multirow[t]{5}{*}{$\begin{array}{l}\text { No } \\
\text { (Private } \\
\text { block } \\
\text { transfer } \\
\text { possible) }\end{array}$} & $\begin{array}{l}\text { State-owned } \\
\text { shares* } \\
\text { (G shares after } \\
\text { recent reform } \\
\text { and tradable) }\end{array}$ & $\begin{array}{l}\text { Shares that are controlled by the central government during the process when firms are } \\
\text { converted into a limited liability corporation but before listing. These shares are either } \\
\text { managed and represented by the Bureau of National Assets Management or held by other } \\
\text { state-owned companies, both of which also appoint firms' board members. After reforms } \\
\text { announced in } 2005 \text { and implemented in } 2006-7 \text { state shares became G shares and are tradable. }\end{array}$ \\
\hline & $\begin{array}{l}\text { Entrepreneur's } \\
\text { shares }\end{array}$ & $\begin{array}{l}\text { Shares reserved for firms' founders during the same process described above; different from } \\
\text { shares that founders can purchase and sell in the markets. }\end{array}$ \\
\hline & Foreign owners & Shares owned by foreign industrial investors during the same process \\
\hline & $\begin{array}{l}\text { Legal entity } \\
\text { holders }\end{array}$ & $\begin{array}{l}\text { Shares sold to legal identities (such as other companies, listed or non-listed) during the same } \\
\text { process. }\end{array}$ \\
\hline & Employee shares & Shares sold to firm’s employees during the same process. \\
\hline \multirow{3}{*}{$\begin{array}{l}\text { Yes } \\
\text { (Newly } \\
\text { issued } \\
\text { shares) }\end{array}$} & A Shares & $\begin{array}{l}\text { Shares issued by Chinese companies that are listed and traded in the Shanghai or Shenzhen } \\
\text { Stock Exchange; most of these shares are sold to and held by Chinese (citizen) investors. }\end{array}$ \\
\hline & B Shares & $\begin{array}{l}\text { Shares issued by Chinese companies that are listed and traded in the Shanghai or Shenzhen } \\
\text { Stock Exchange; these shares are sold to and held by foreign investors; starting in } \\
\text { 2001Chinese investors can also trade these shares. }\end{array}$ \\
\hline & H Shares & $\begin{array}{l}\text { Shares issued by selected Chinese companies listed and traded in the Hong Kong Stock } \\
\text { Exchange; these shares can only be traded on the HK Exchange but can be held by anyone. }\end{array}$ \\
\hline
\end{tabular}

*: There are sub-categories under this definition

Table 6-B Tradable vs. Non-tradable Shares for China's Listed Companies

\begin{tabular}{lccccc}
\hline Year & $\begin{array}{l}\text { Shanghai SE: } \\
\text { State/total } \\
\text { shares }\end{array}$ & $\begin{array}{l}\wedge \text { Non-tradable/total } \\
\text { shares }\end{array}$ & $\begin{array}{l}\text { Tradable/total } \\
\text { shares }\end{array}$ & $\begin{array}{c}\text { A/total shares } \\
\text { A/Tradable } \\
\text { shares }\end{array}$ \\
\hline 1992 & 0.41 & 0.69 & 0.31 & 0.16 & 0.52 \\
1993 & 0.49 & 0.72 & 0.28 & 0.16 & 0.57 \\
1994 & 0.43 & 0.67 & 0.33 & 0.21 & 0.64 \\
1995 & 0.39 & 0.64 & 0.36 & 0.21 & 0.60 \\
1996 & 0.35 & 0.65 & 0.35 & 0.22 & 0.62 \\
1997 & 0.32 & 0.65 & 0.35 & 0.23 & 0.66 \\
1998 & 0.34 & 0.66 & 0.34 & 0.24 & 0.71 \\
1999 & 0.43 & 0.65 & 0.35 & 0.26 & 0.75 \\
2000 & 0.44 & 0.64 & 0.36 & 0.28 & 0.80 \\
2001 & 0.50 & 0.64 & 0.36 & 0.29 & 0.80 \\
2002 & 0.52 & 0.65 & 0.35 & 0.26 & 0.74 \\
2003 & 0.57 & 0.64 & 0.35 & 0.27 & 0.76 \\
2004 & 0.58 & 0.64 & 0.36 & 0.28 & 0.77 \\
2005 & 0.57 & 0.62 & 0.38 & 0.30 & 0.78 \\
2006 & 0.36 & 0.65 & 0.35 & 0.27 & 0.81 \\
2007 & 0.37 & 0.69 & 0.31 & 0.28 & 0.90 \\
2008 & 0.47 & 0.58 & 0.42 & 0.37 & 0.91 \\
2009 & 0.49 & 0.53 & 0.47 & 0.50 & 0.98 \\
\hline
\end{tabular}

$\wedge$ : Non-tradable shares include "state-owned" and "shares owned by legal entities";

This column is calculated as "(Non-tradable in Shanghai SE+ Non-tradable in Shenzhen SE)/(Market cap in

Shanghai SE + Market cap in Shenzhen SE)”

*: tradable shares include A, B, and H shares;

Source: China Security Regulation Committee Reports (2000-2006), CEIC database and http://www.csrc.gov.cn 
Table 7 Trading Volume of National Interbank Market (RMB billion)

\begin{tabular}{lrrrrrrr}
\hline Maturity & Overnight & \multicolumn{1}{c}{ 7 days } & 20 days & 30 days & 60 days & 90 days & 120 days \\
\hline 2001 & 103.88 & 560.69 & 93.35 & 35.28 & 9.40 & 4.73 & 0.87 \\
2002 & 201.52 & 852.34 & 100.35 & 29.17 & 10.78 & 4.76 & 11.81 \\
2003 & 641.89 & $1,456.31$ & 56.60 & 44.11 & 10.14 & 10.18 & 2.81 \\
2004 & 283.34 & 1041.41 & 30.67 & 18.93 & 9.20 & 5.84 & 2.57 \\
2005 & 223.03 & 896.26 & 60.42 & 29.91 & 7.51 & 14.09 & 1.54 \\
2006 & 635.21 & 1290.43 & 38.13 & 19.11 & 12.03 & 5.22 & 1.41 \\
2007 & 8030.47 & 2178.01 & 50.16 & 34.16 & 27.94 & 31.80 & 13.34 \\
2008 & 10651.36 & 3500.47 & 110.71 & 113.55 & 44.52 & 66.61 & 18.50 \\
2009 & 16166.60 & 2134.79 & 102.15 & 204.84 & 53.80 & 71.00 & 62.3 \\
2010 & 24486.20 & 2426.90 & 65.01 & 161.30 & 46.61 & 134.02 & 19.75 \\
\hline
\end{tabular}

Source: The People’s Bank of China (2001-2010). 
Figure 1 Overview of China's Financial System

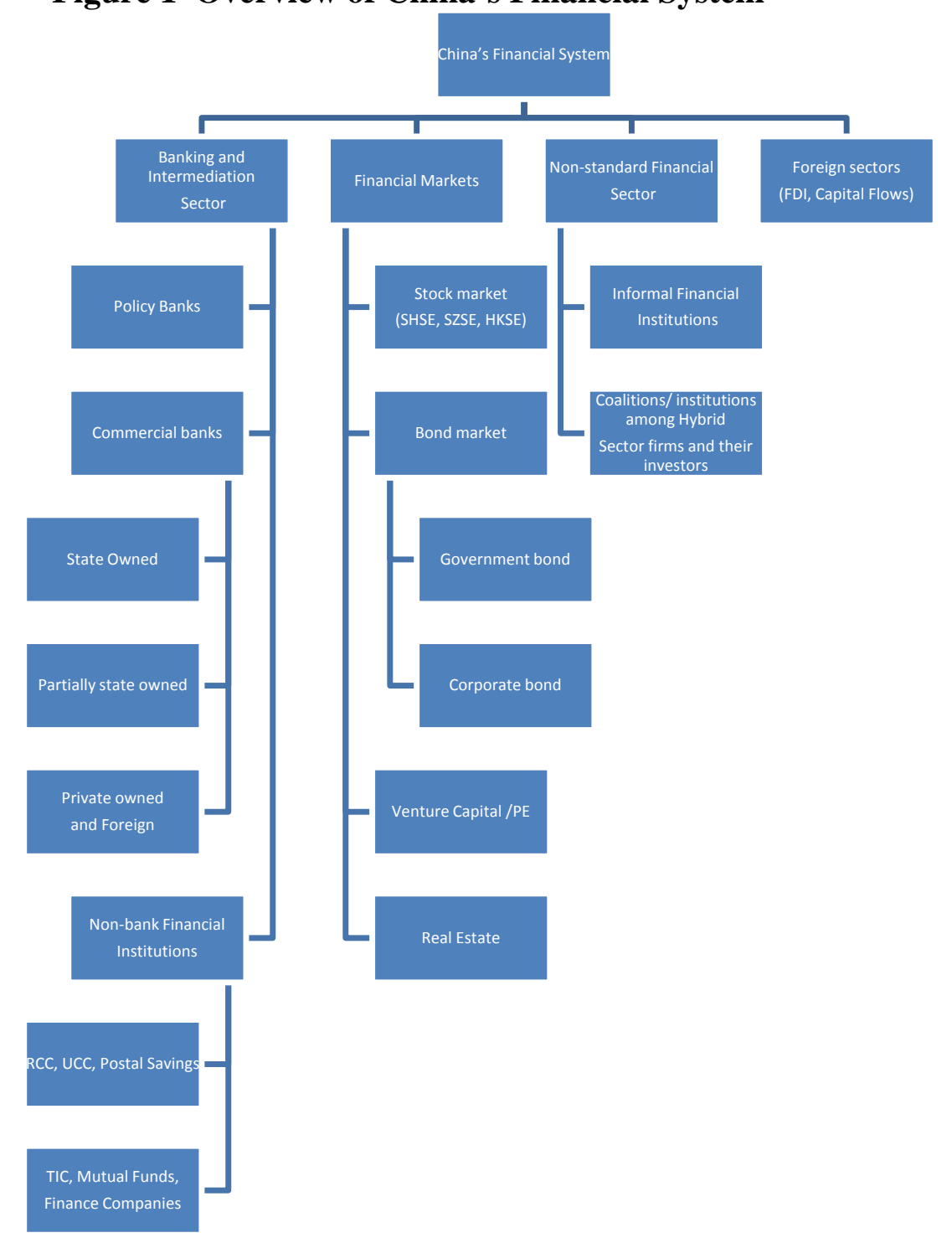




\section{Components of Bank Deposits}

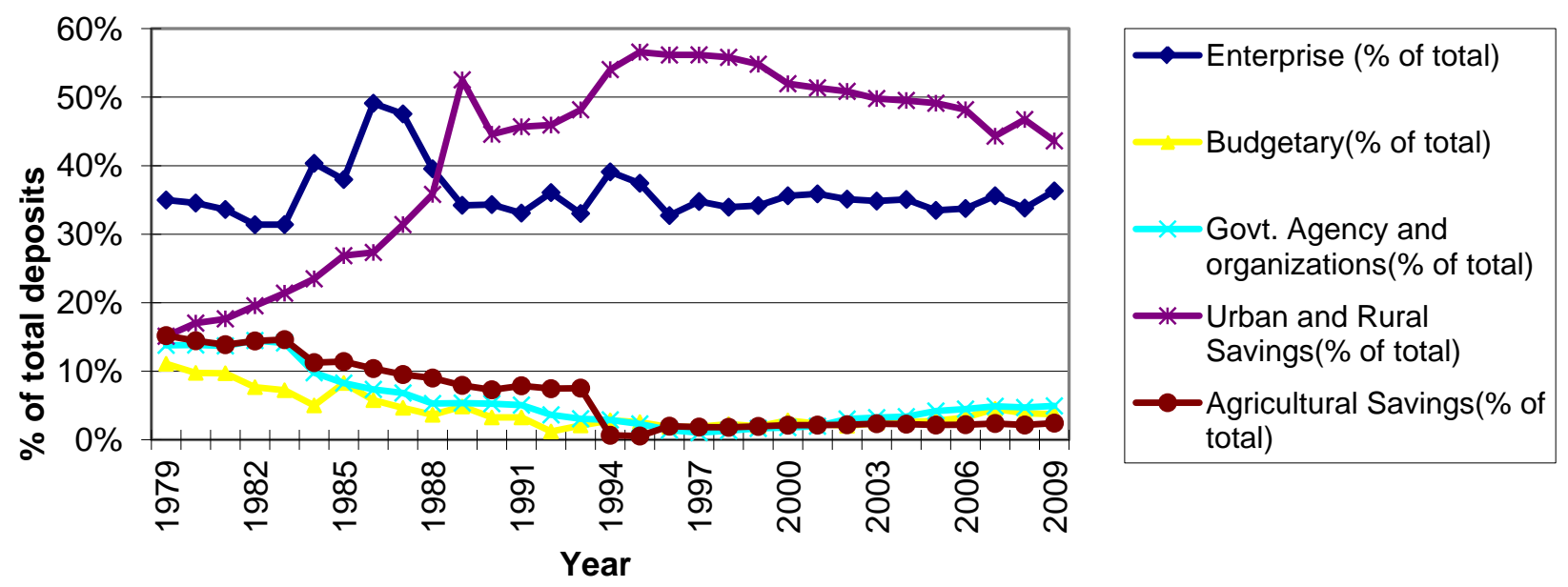

Figure 2-A Sources for Bank Deposits in China

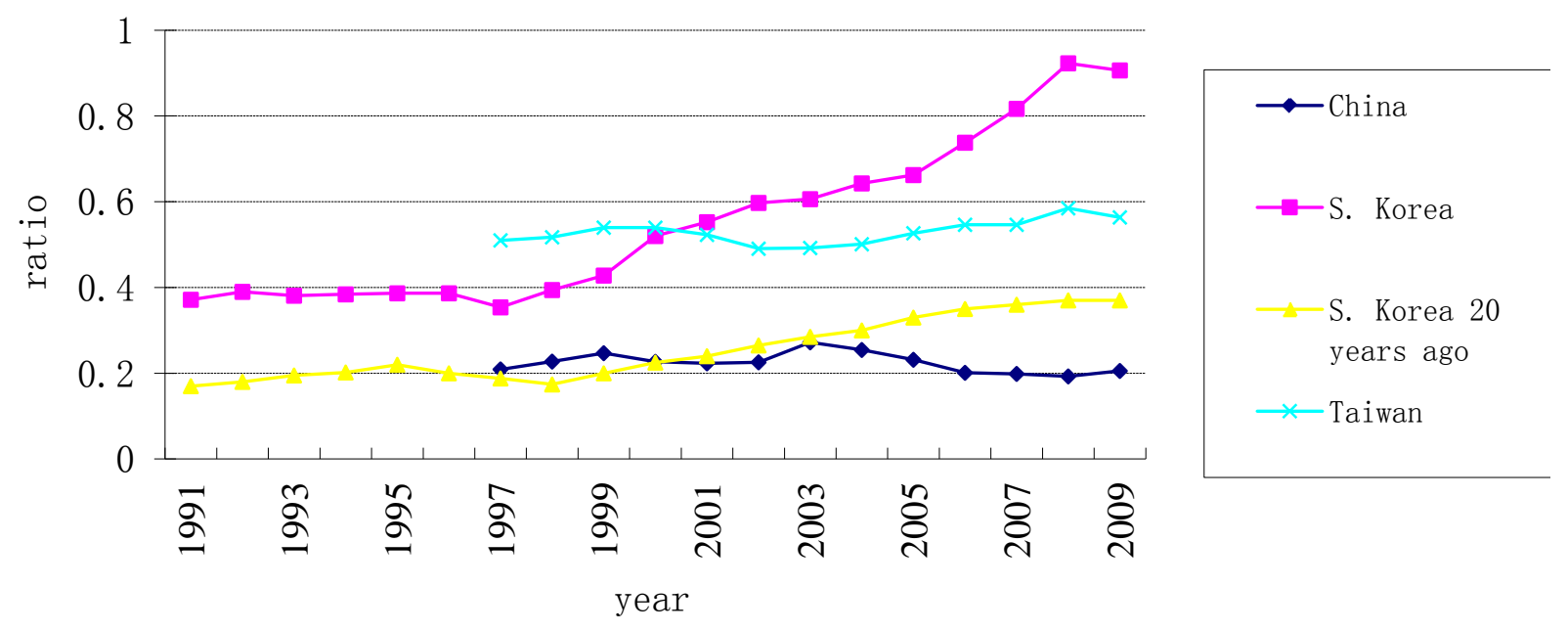

Figure 2-B Comparing Total Bank Credit extended to private/hybrid sectors 
Assets Managed by Insurance Companies

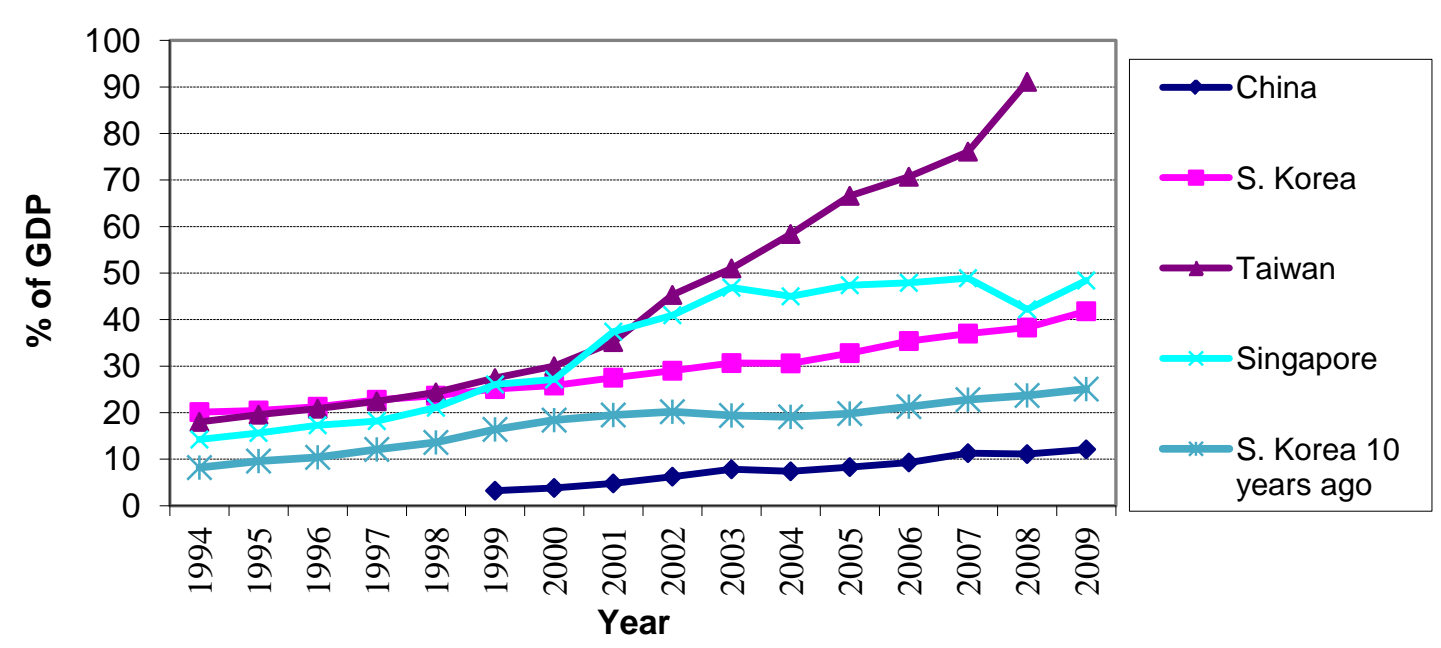

Figure 2-C A Comparison of Assets Under Management of Insurance Companies

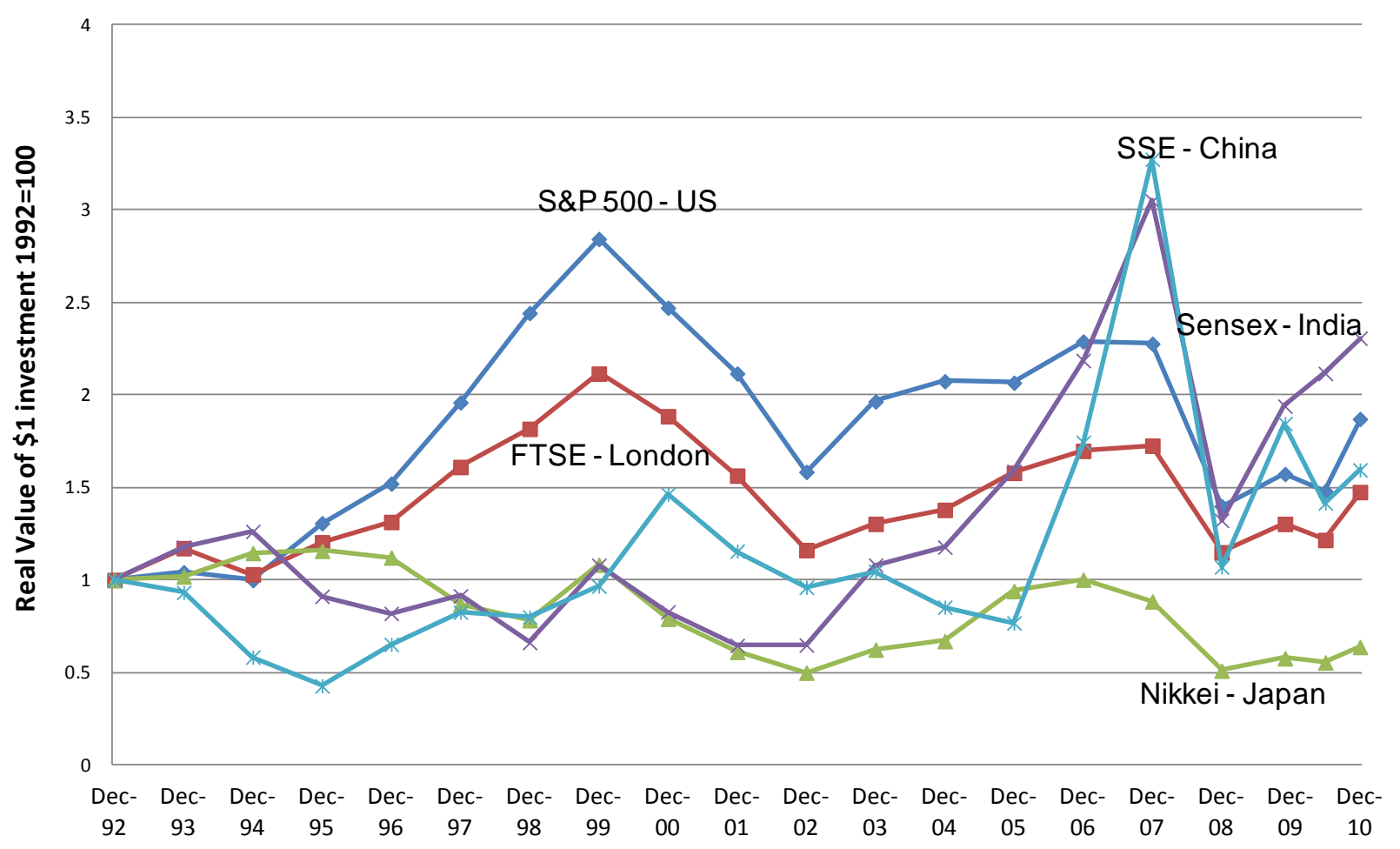

Figure 3 A Comparison of Performance of Major Stock Indexes (Buy-and-hold returns of \$1 between Dec. 1992 and Dec. 2010) 


\section{Real Estate Investment (1996-2009)}

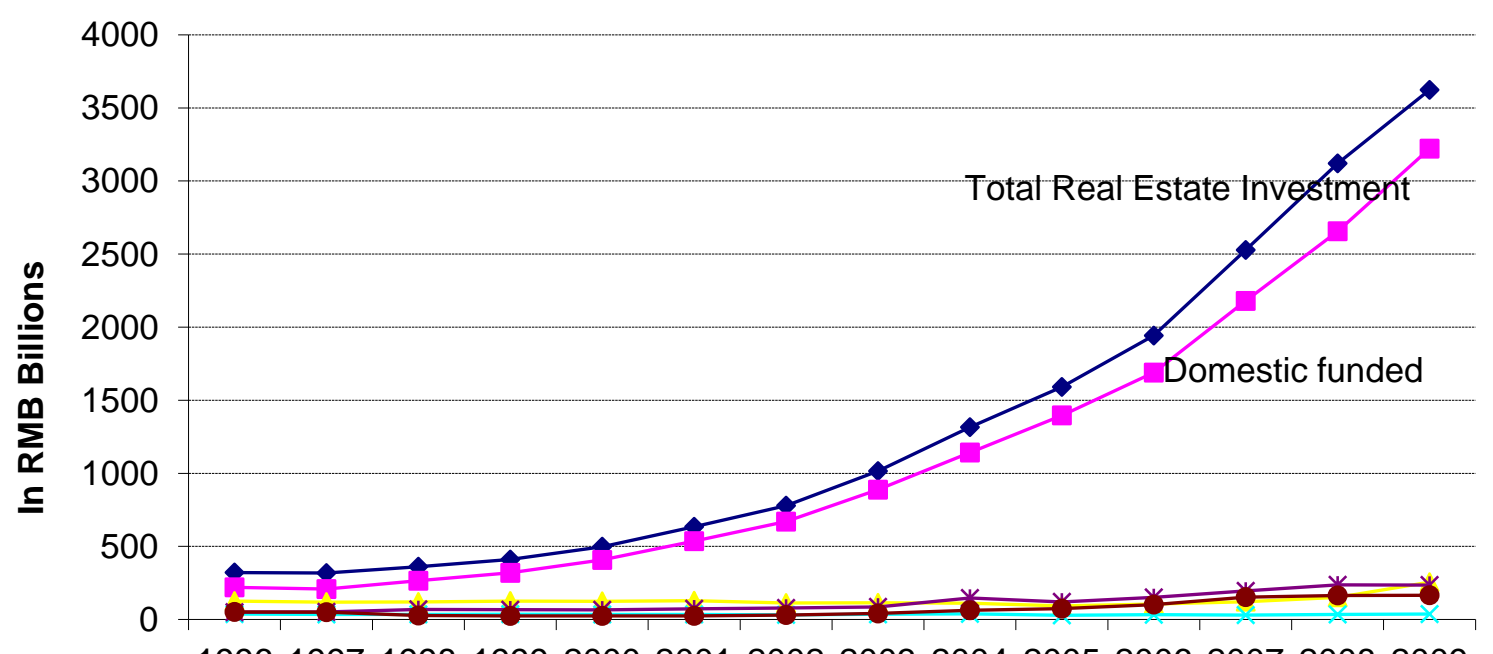

19961997199819992000200120022003200420052006200720082009

Year

\section{Real Estate Investment (1996-2009) bottom part of the graph (same colors)}

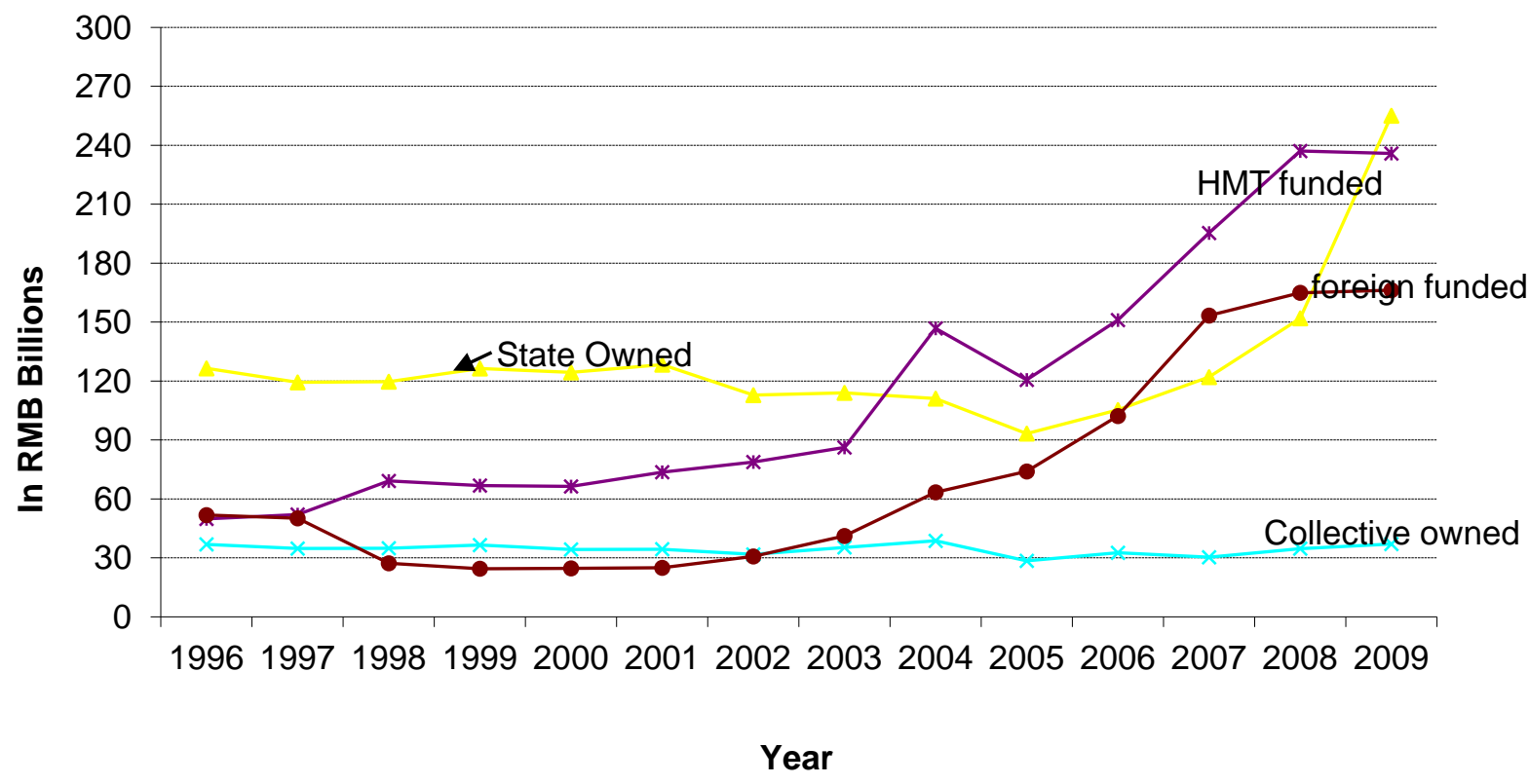

Figure 4-A Total Real Estate Investments and their sources (1996-2009)

Bottom part of the figure in the top panel is enlarged and plotted in the bottom panel, which presents the funding sources of real estate investment over the period of 1996-2009. 


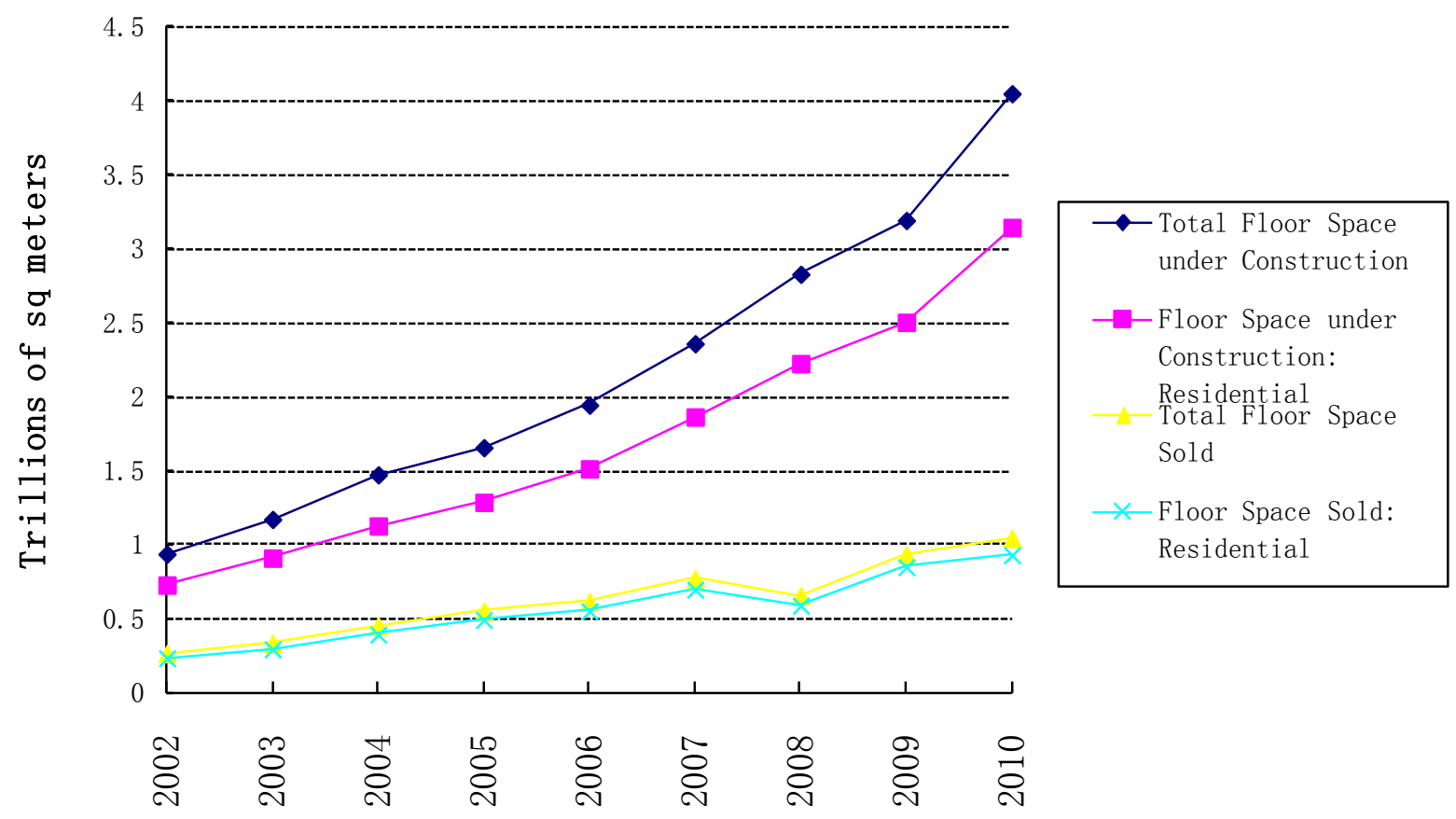

Figure 4-B Total Floor Space (developed vs. sold) in China (data source for Figures 4-B and 4-C: CEIC)

Normalized chart, $2002=100$
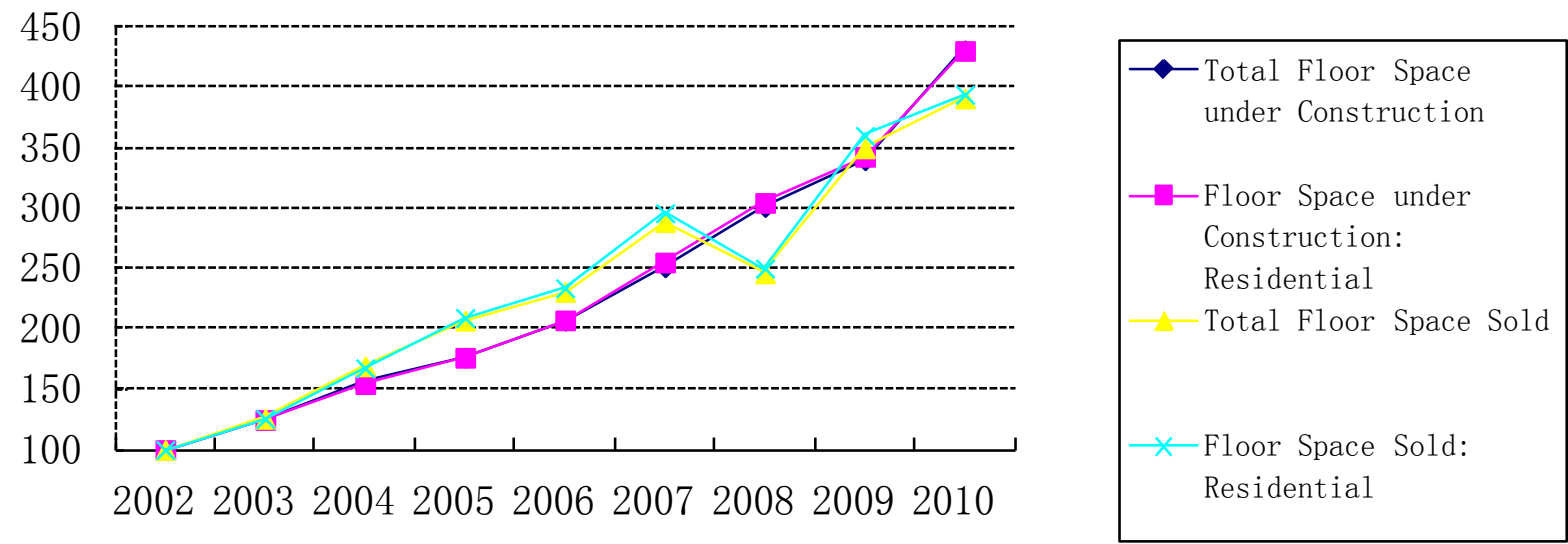

Figure 4-C Growth Rats in Total Floor Space (developed vs. sold) in China 
National Housing Price vs Disposable Annual Income

Normalized, base year $=2002$

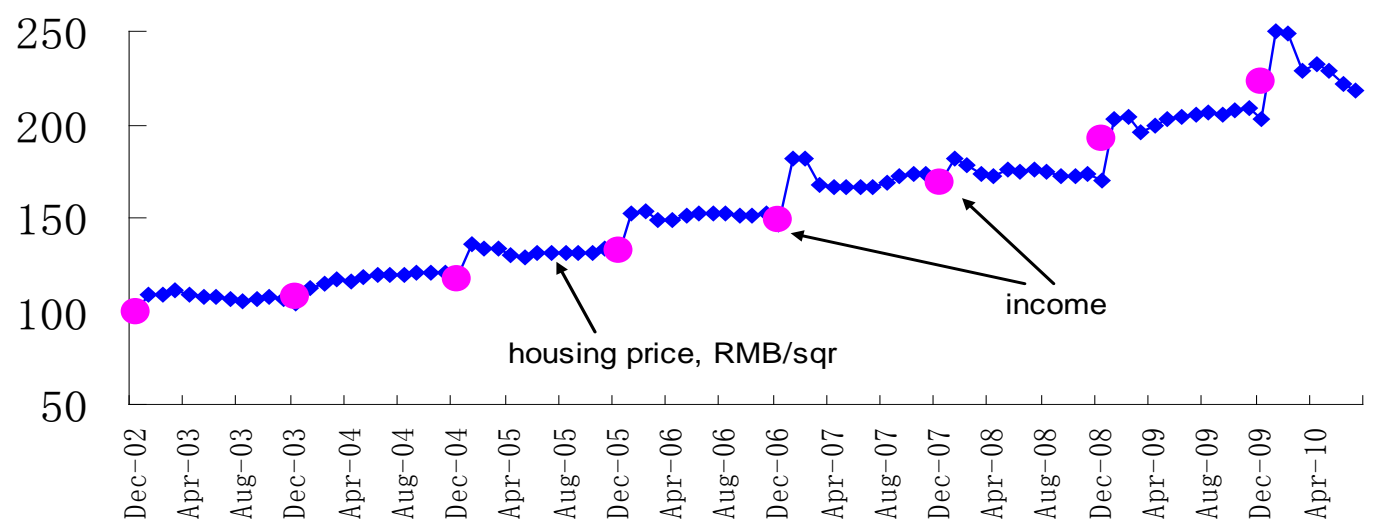

Figure 5-A: Comparing the growth of National Housing Prices and Disposable Household Income (data source for Figures 5-A through 5-E: CEIC)

Beijing Housing Price vs Disposable Annual Income

Normalized, base year $=2002$

adjusted by CPI, 2002 $=100$

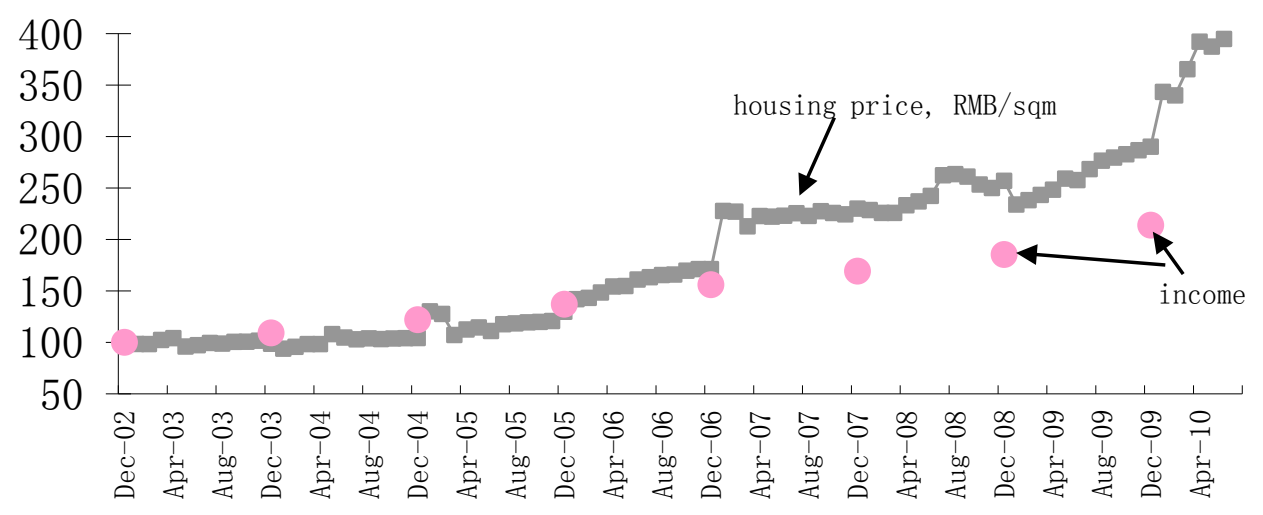

Figure 5-B: Growth of Housing Prices and Disposable Household Income in Beijing 
Shanghai Housing Price vs Disposable Annual Income per capita adjusted by CPI, 2002=100

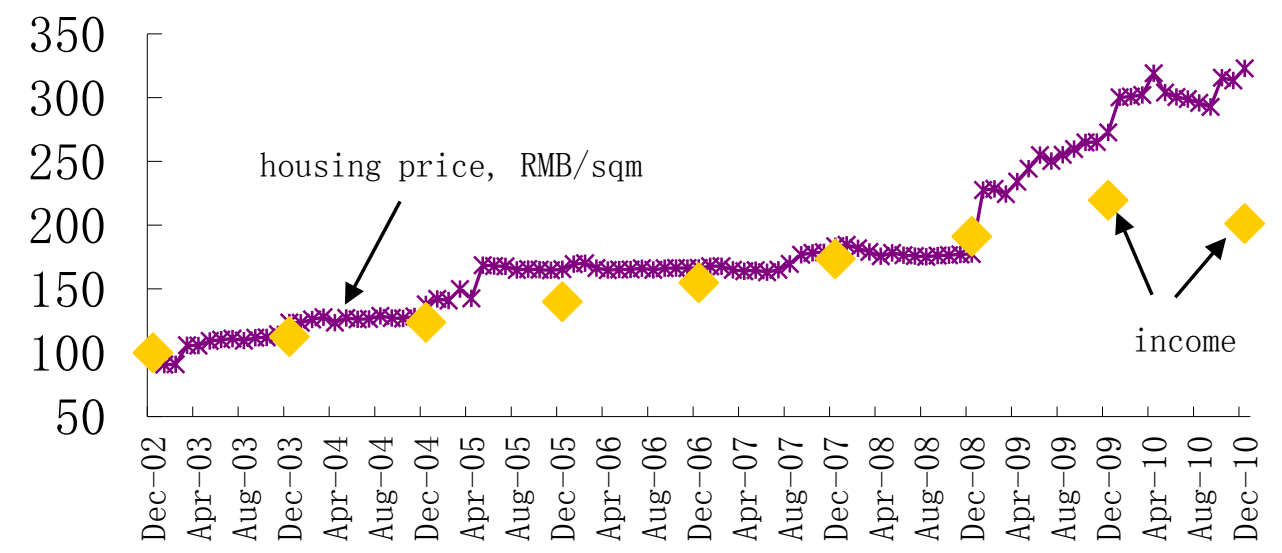

Figure 5-C: Growth of Housing Prices and Disposable Household Income in Shanghai

Shenzhen Housing Price vs Disposable Annual Income per capita adjusted by CPI, 2002=100

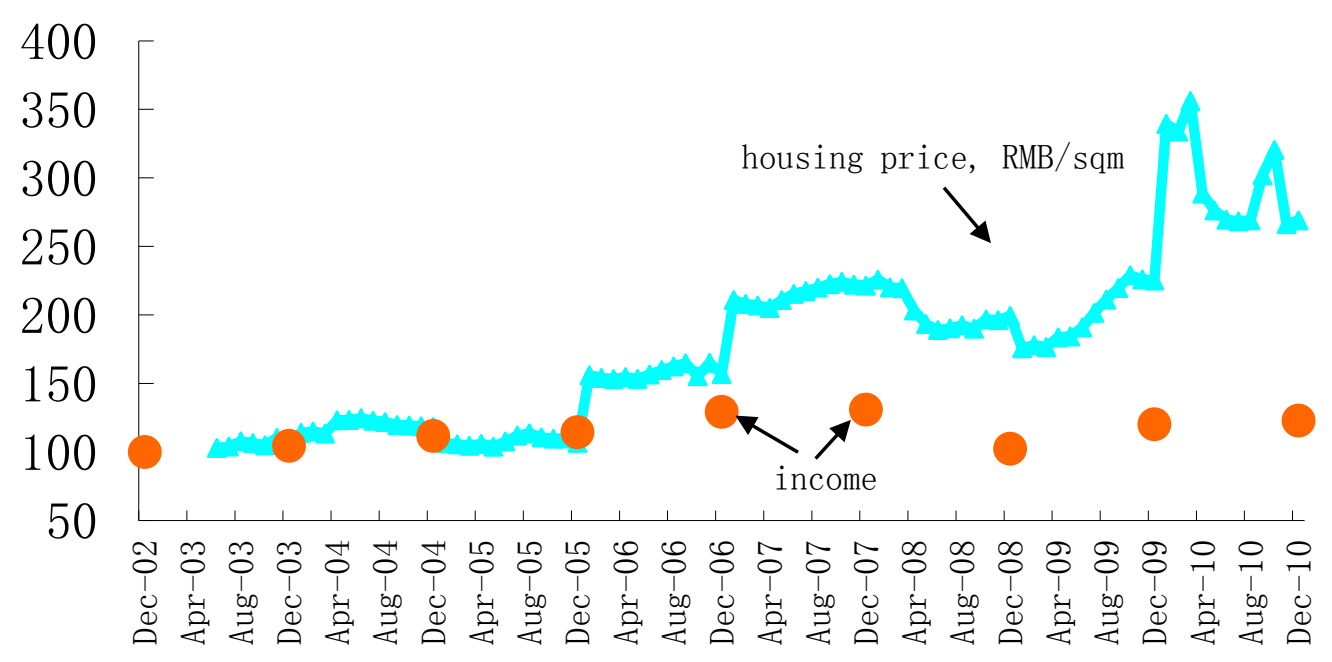

Figure 5-D: Growth of Housing Prices and Disposable Household Income in Shenzhen 
Guanzhou Housing Price vs Disposable Annual Income

Normalized, base year $=2002$

adjusted by CPI, 2002=100

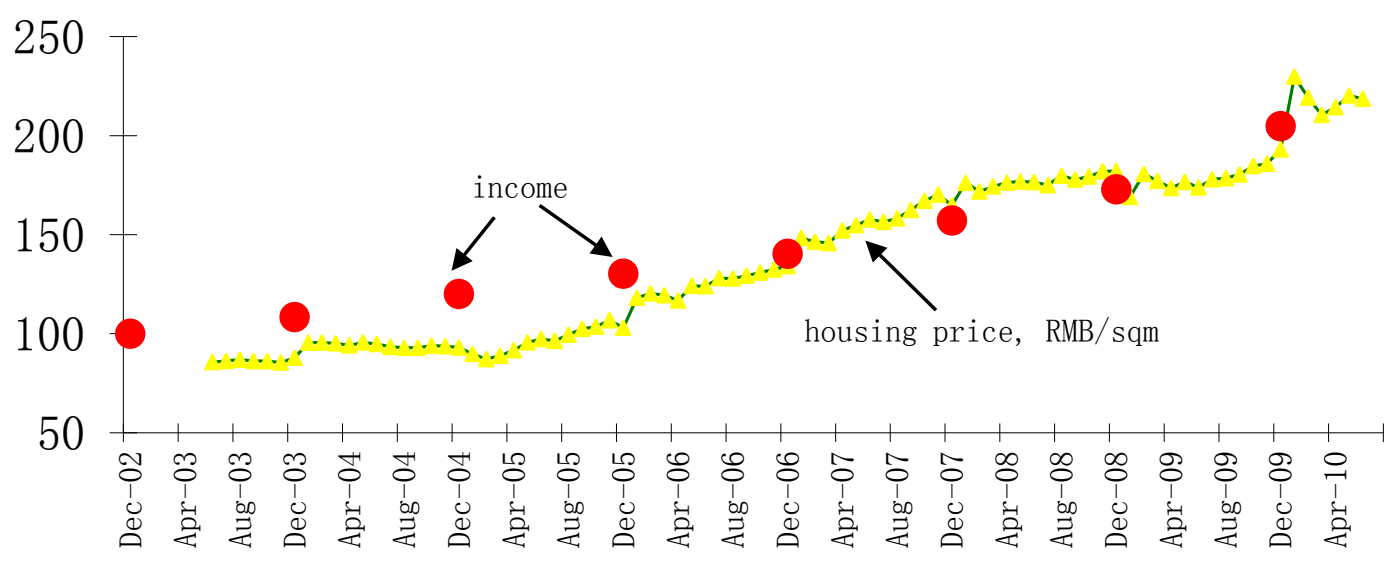

Figure 5-E: Growth of Housing Prices and Disposable Household Income in Guangzhou

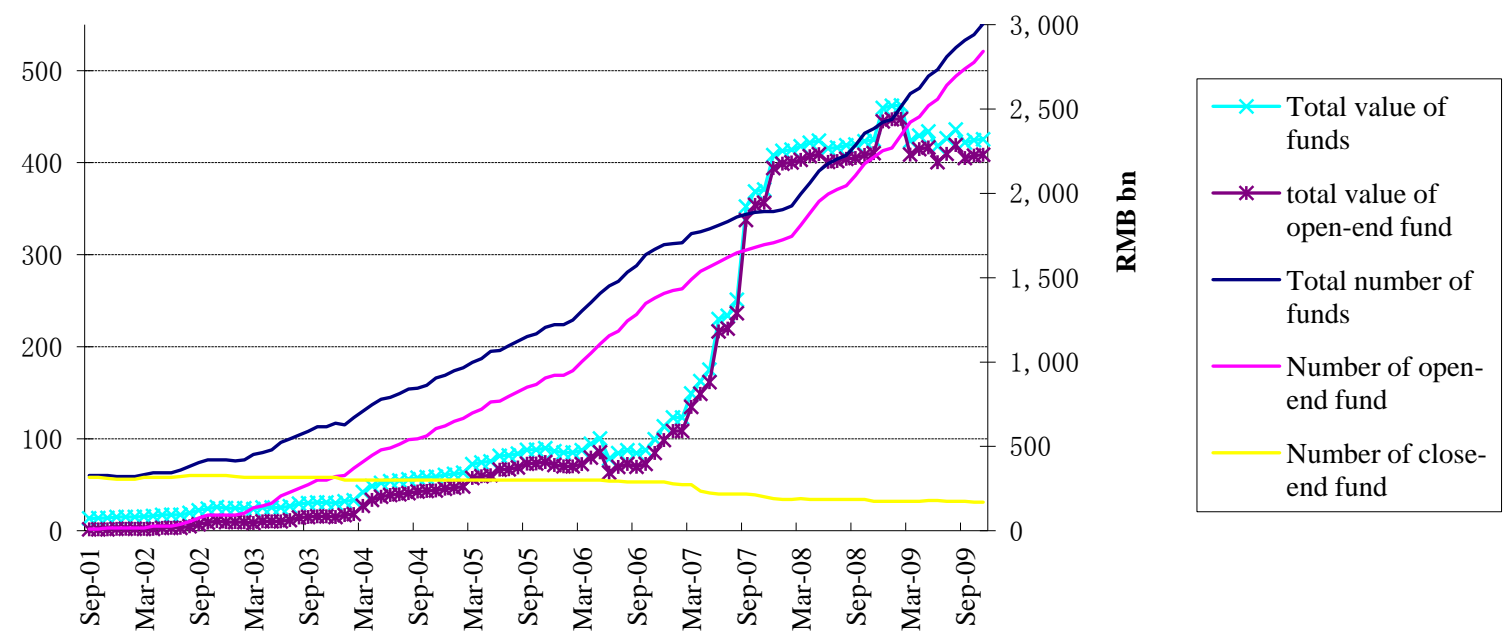

Figure 6 Growth in China's Mutual Fund Industry (1998-2009) 


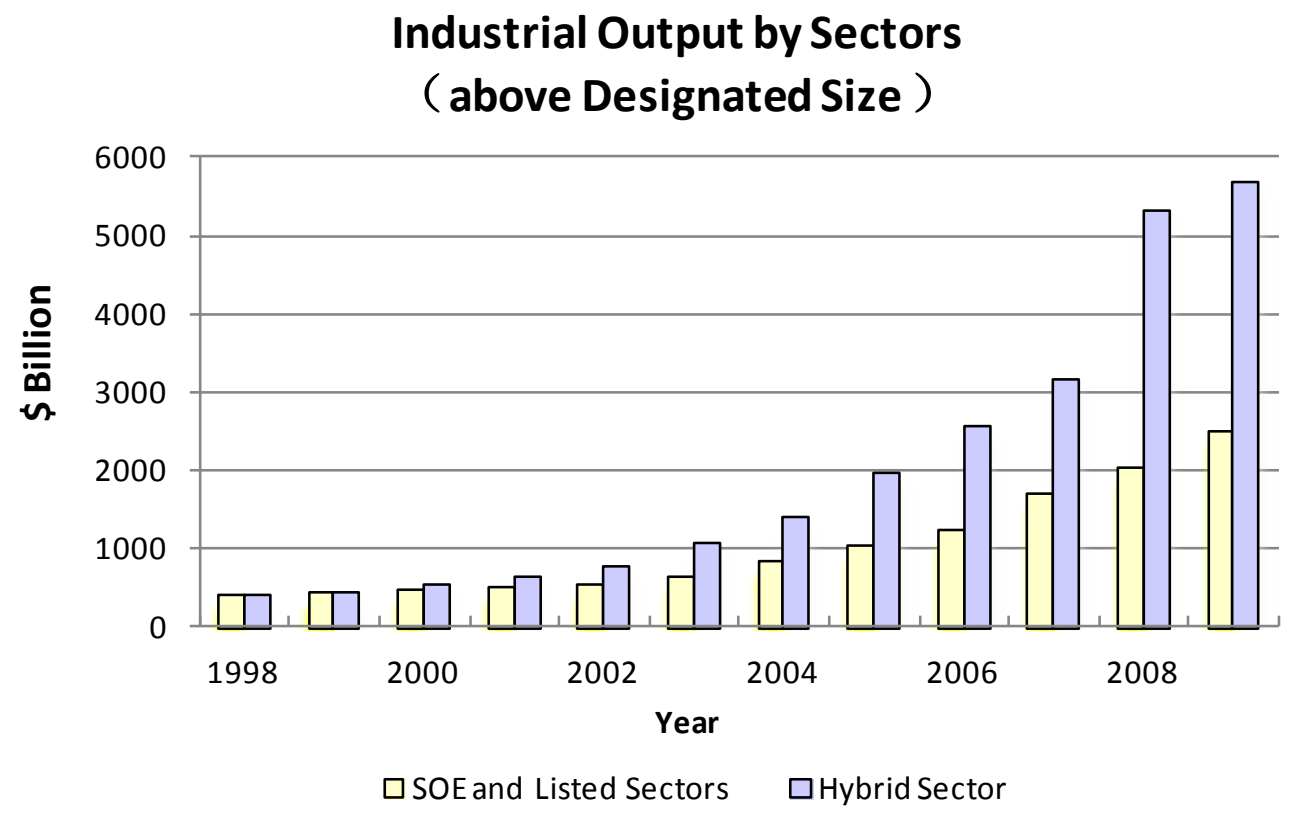

Figure 7-A Comparing the Sectors - Industrial Output

In this figure we plot total "industrial output" for State (SOEs) and Listed (publicly listed and traded firms) Sectors combined and for the Hybrid Sector (all the rest of the firms) during 2000 to 2008. Data source for this table is the Chinese Statistical Yearbook (2000 - 2009).

\section{Employment by Sectors}

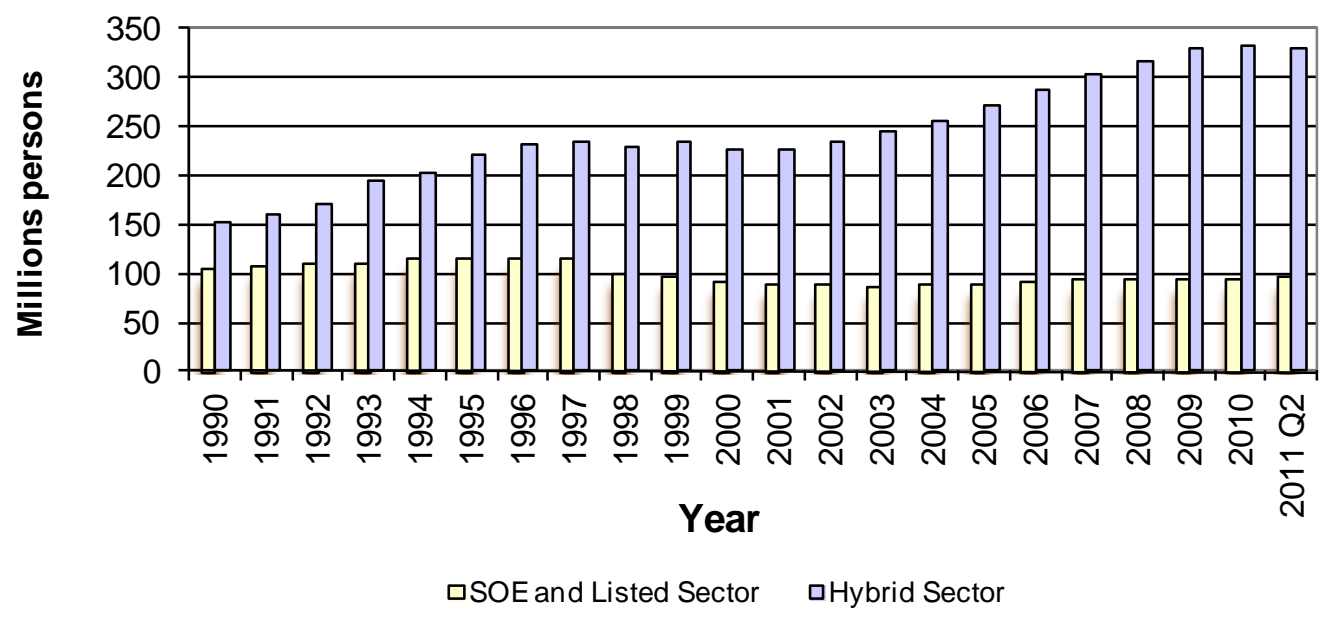

Figure 7-B Comparing the Sectors - Employment

In this figure we plot total number of workers employed by the State (SOEs) and Listed (publicly listed and traded firms) Sectors combined and by the Hybrid Sector (all the rest of the firms) during 1990 to 2008. Data source for this table is the Chinese Statistical Yearbook and CEIC database . 
Exchange Rate of RMB/USD and HK/USD (2000-Sept. 2011)

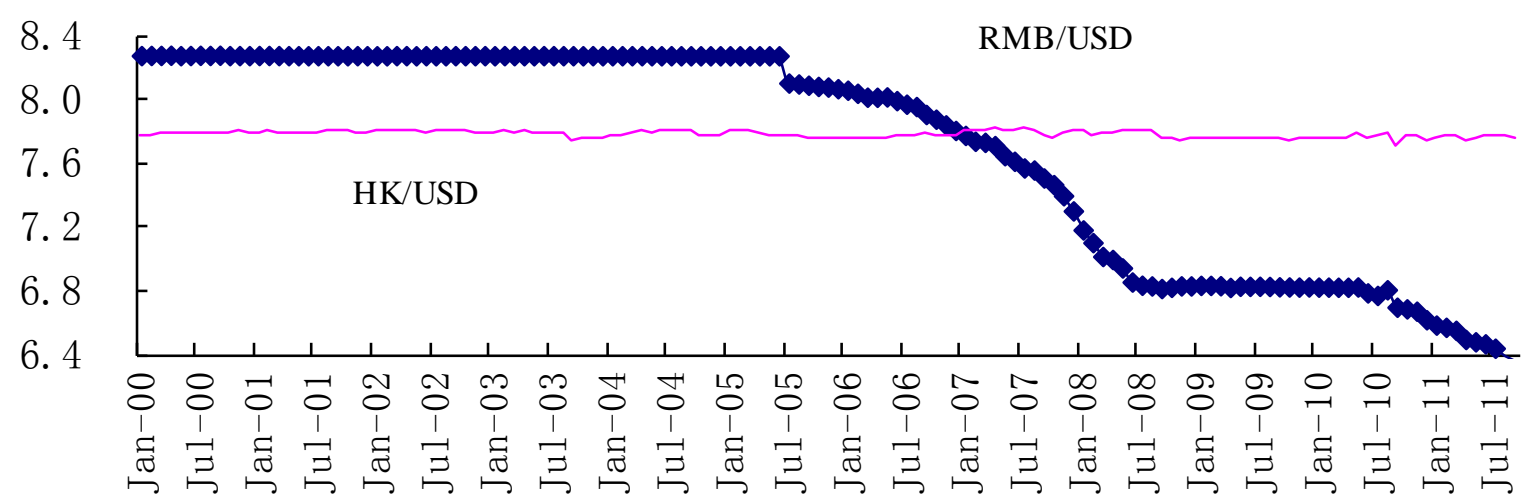

Date

Figure 8-A Trends of Exchange Rates (US\$, RMB, and HK\$)

Foreign Exchange Reserve: Flows and Stocks

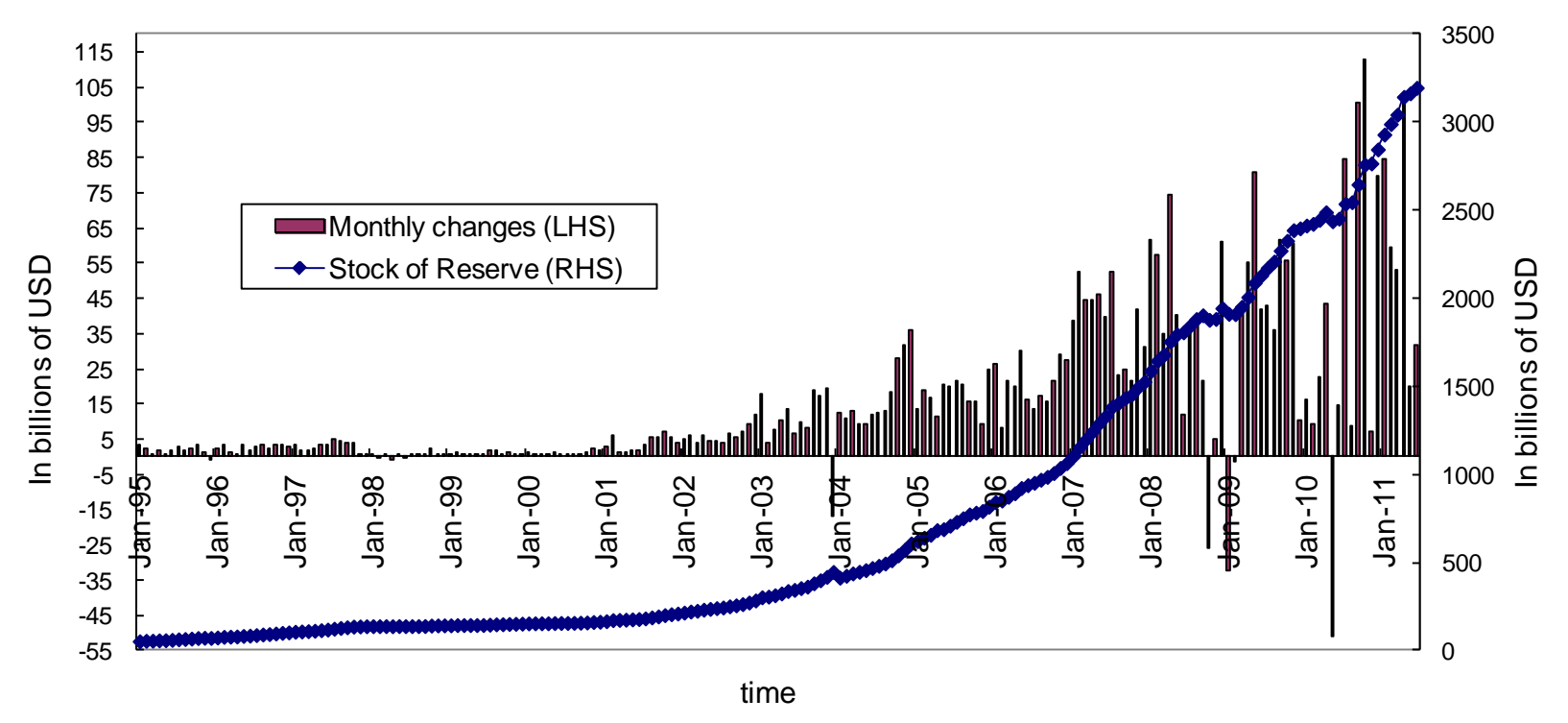

Figure 8-B China's Foreign Exchange Reserves 